San Jose State University

SJSU ScholarWorks

Master's Theses

Master's Theses and Graduate Research

Summer 2018

\title{
Diets and Stable Isotope Signatures of Yellowtail Rockfish (Sebastes flavidus) in Central California
}

Jennifer Chiu

San Jose State University

Follow this and additional works at: https://scholarworks.sjsu.edu/etd_theses

\section{Recommended Citation}

Chiu, Jennifer, "Diets and Stable Isotope Signatures of Yellowtail Rockfish (Sebastes flavidus) in Central California" (2018). Master's Theses. 4931.

DOI: https://doi.org/10.31979/etd.52x9-rjw5

https://scholarworks.sjsu.edu/etd_theses/4931

This Thesis is brought to you for free and open access by the Master's Theses and Graduate Research at SJSU ScholarWorks. It has been accepted for inclusion in Master's Theses by an authorized administrator of SJSU ScholarWorks. For more information, please contact scholarworks@sjsu.edu. 


\title{
DIETS AND STABLE ISOTOPE SIGNATURES OF YELLOWTAIL ROCKFISH (SEBASTES FLAVIDUS) IN CENTRAL CALIFORNIA
}

\author{
A Thesis \\ Presented to \\ The Faculty of Moss Landing Marine Laboratories \\ San José State University \\ In Partial Fulfillment \\ of the Requirements for the Degree \\ Master of Science \\ by \\ Jennifer A. Chiu
}

August 2018 
(C) 2018

Jennifer A. Chiu

ALL RIGHTS RESERVED 
The Designated Thesis Committee Approves the Thesis Titled

DIETS AND STABLE ISOTOPE SIGNATURES OF YELLOWTAIL ROCKFISH (SEBASTES FLAVIDUS) IN CENTRAL CALIFORNIA

\author{
by \\ Jennifer A. Chiu \\ APPROVED FOR THE DEPARTMENT OF MARINE SCIENCE \\ SAN JOSÉ STATE UNIVERSITY
}

August 2018

Dr. Richard M. Starr

Dr. Scott L. Hamilton

Dr. Kenneth H. Coale
Moss Landing Marine Laboratories

Moss Landing Marine Laboratories

Moss Landing Marine Laboratories 


\title{
ABSTRACT
}

\section{DIETS AND STABLE ISOTOPE SIGNATURES OF YELLOWTAIL ROCKFISH (SEBASTES FLAVIDUS) IN CENTRAL CALIFORNIA}

\author{
by Jennifer A. Chiu
}

Studies of fish diets can improve the understanding of trophic distributions and the predatory role of a species in an ecosystem. Identifying the spatial and temporal variability in the diets of fishes can provide useful information for stock assessments and management. Yellowtail Rockfish (Sebastes flavidus) are a commercially and recreationally important fishery species, and abundant along the central California coast, yet the most recent studies of diets occurred over 20 years ago in Oregon and Washington. To provide current information from California, I examined the food habits of Yellowtail Rockfish collected near Cordell Bank, the Farallon Islands, and Half Moon Bay in 2013 and 2014 using gut content and stable isotope analyses. Yellowtail Rockfish analyzed in this study were semi-pelagic predators, feeding primarily on tunicates, crustaceans, and teleosts. Based on $\delta^{15} \mathrm{~N}$ values, fish caught in 2013, on average, were feeding at lower trophic levels than those caught in 2014 , and $\delta^{13} \mathrm{C}$ values indicated that fish caught at the northern-most sites were feeding on more pelagic-influenced carbon sources. Yellowtail Rockfish in central California can be described as opportunistic feeders because predation patterns were temporally localized, and diets consisted mostly of transitory prey sources. The Yellowtail Rockfish diet information presented in this study fills data gaps of a key life history component, and will be useful for future stock assessments. 


\section{ACKNOWLEDGMENTS}

Financial and logistical support for this research was provided by Moss Landing Marine Laboratories (MLML) (Sonia Linnik Hamilton Marine Science Scholarship and Signe Lundstrum Memorial Scholarship), San José State University (SJSU) (H. Thomas Harvey Research Fellowship), California Sea Grant Extension Program, National Marine Fisheries Service (NMFS), Undergraduate Research Opportunities Center (UROC) at CSU Monterey Bay, Dr. Earl H. Myers and Ethel M. Myers Oceanographic and Marine Biology Trust, and the David and Lucille Packard Foundation.

I would like to thank the members of my thesis committee at MLML: Dr. Rick Starr, Dr. Scott Hamilton, and Dr. Kenneth Coale. Your words of encouragement and guidance throughout the scientific process were invaluable. I sincerely appreciate all of the time and effort you have invested in me, and the continuous push to make me a better scientist. Rick, thank you for providing me the opportunity to work in your lab from day one, and fostering my professional growth. The skills I have acquired through my work with CCFRP will stay with long beyond grad school, and I feel fortunate to have been a part of such an incredible program.

This work would not have been possible without the Rockfish Conservation Area (RCA) Project, a collaborative effort among the California Department of Fish and Wildlife, NMFS, Cordell Bank National Marine Sanctuary, and MLML. Thank you for allowing me to conduct my research in tandem with yours. And to 
the volunteer anglers, CPFV captains, deckhands, and science crew aboard these research trips: your dedication and support of our research was unparalleled, and I'm fortunate to have collaborated with such talented people.

Inspiration for this research, in part, stemmed from previous Yellowtail Rockfish diet work conducted by Rick Brodeur in the Northeastern Pacific Ocean. Meeting you at the Western Groundfish Conference in Newport, Oregon, was a highlight for me, and I appreciate you taking the time to talk with me about my work. Your genuine interest propelled me forward and brought a new, and muchneeded, spark that I was lacking.

The assistance provided during my in-lab processing and dissections was crucial to the success of this work. In particular, I am in debt to my amazing UROC intern, Emily Doyle. Emily, the dedication, persistence, and enthusiasm you brought to lab every day was infectious. No matter what the task was for the day, you were always up for the challenge, and never once complained about having to count hundreds of salps or Euphausiid eyeballs. Even after your internship had ended, you still dedicated hours upon hours of your week to this work, and I could not be more thankful. The victories from this research also belong to you, and I'm so proud to have mentored and worked beside you. You are a wonderful scientist, and even better human being.

I'd also like to thank Stacy Kim, Valerie Loeb, Dorota Szuta, Christine Mann, Gregor Cailliet, John Field, Jim Harvey, Kyra Schlining, Anela Choi, Donna Kline, Andrew Harmer, and Peter Slattery for all of their assistance with identifying 
digested Yellowtail Rockfish stomach contents. It was challenging in many cases, and I appreciate the time taken to look through specimens and photos, and provide your expert advice. Thanks also to Selena McMillan for providing me countless resources on diet studies and analyses.

My stable isotope support team deserves a great deal of praise. Thank you to Rachel Zuercher and Rob Franks at the Marine Analytical Laboratory at UC Santa Cruz for allowing me to freeze-dry my samples at your facility and assisting me with the process. Steve Cunningham, thank you for teaching me how to use the microbalance at MLML. Despite being a dinosaur, it got the job done. Thanks also to Kim Null and the Trace Metals Laboratory for permitting use of the instrument. This research would not have been successful without the guidance and expertise of Bruce Finney at Idaho State University. I am grateful for all of the advice you provided, for your words of encouragement, and for answering the never-ending questions I posed. Thanks also to Million Hailemichael at ISU for processing my samples in such a timely manner.

On the data analysis side, I have to extend a huge thank you to Joe Bizzarro and Ryan Fields. Joe, I learned so much from you through this process; your expertise with diet studies and analyses in incredible. I appreciate the countless meetings we had and emails we exchanged to ensure that my statistical models were just right. Thank you for taking an interest in my project, and investing so much time into the final product. Ryan, you are an R-genius. Thank you for sending me sample code, being my encyclopedia for interpreting outputs when 
Google left me more confused, and being on-call for all of my stats woes. You are a great scientist, and I am fortunate to have worked with you throughout my entire time at MLML.

My success as a graduate student is directly tied to the support system MLML provides. The front desk, IT personnel, facilities team, faculty, and staff make this a special place to work and conduct research. To the past and present members of the Fisheries and Conservation Biology Lab that I have had the pleasure of working with...thank you for your encouragement and friendship throughout my time at MLML. From hundreds of hours spent on CCFRP trips to survival suit races and knot tying competitions in lab meetings, my graduate school experience was changed for the better because of the experiences shared together. And to the Lunch Bunch! You girls mean everything to me, and it's safe to say that graduate school would have been so different without you! Thank you for assisting with dissections, providing advice on statistics, and most importantly, being the solid foundation I could rely on when things got tough. You could always relate to what I was going through, and knew just the right words to say to get me back on track. I'm so proud of all that you have accomplished, and can't wait to see how our careers evolve from here. Now we just have to figure out how to get Lemongrass wherever we end up.

Mom, Dad, and Cynthia...thank you for supporting me in whatever avenue I wanted to pursue. You didn't bat an eye when I said I wanted to become a marine biologist all those years ago, and did nothing but encourage the pursuit of 
this passion. I am incredibly lucky to have you as my cheerleaders, and to be surrounded by such love and compassion. It has been a long journey, and your unwavering support (and the persistent "are you done yet?") has pushed me to the finish line. And finally to Andy...you have been my rock throughout this entire process. You made me believe I could do this, even when I couldn't see the light at the end of the tunnel. The confidence you have instilled in me has had profound impacts, and I still can't believe I get to experience life by your side forever. You inspire me everyday, and I strive to be a more selfless, kind, and generous person like you. 


\section{TABLE OF CONTENTS}

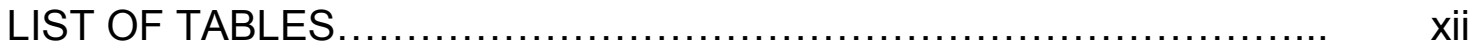

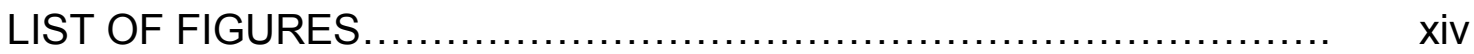

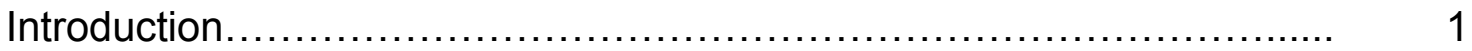

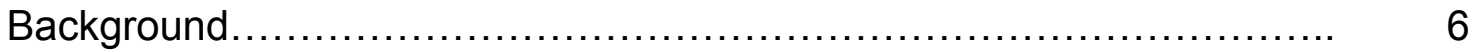

Gut Content Analysis................................................... 6

Stable Isotope Analysis.......................................... 8

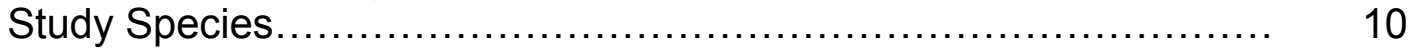

Materials and Methods................................................. 14

Study Area ........................................................ 14

Sample Collection............................................... 16

Gut Content Analysis............................................. 17

Dissections...................................................... 17

Describing stomach contents.................................. 17

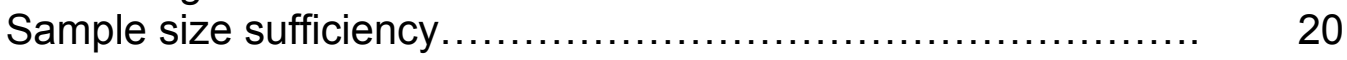

Trophic level................................................. 22

Determining effects of temporal and spatial factors on diet......... 22

Stable Isotope Analysis........................................... $\quad 25$

Sample preparation........................................... 25

Delta notation................................................ 26

$\delta^{13} \mathrm{C}$ correction ............................................................ 27

Variability in $\delta^{13} \mathrm{C}$ and $\delta^{15} \mathrm{~N}$ based on Total Length, Location and

Year................................................................. 27

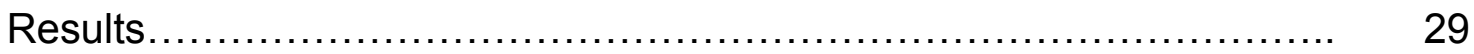

Gut Content Analysis..................................................... 29

Overall diet description......................................... $\quad 30$

Sample size sufficiency....................................... 33

Diet description using generalized taxonomic distinctions........... $\quad 40$

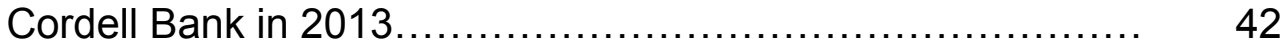

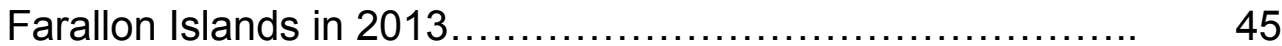

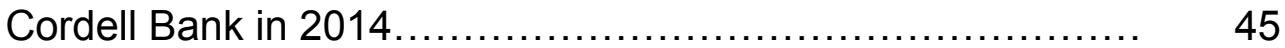

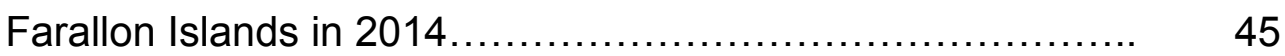

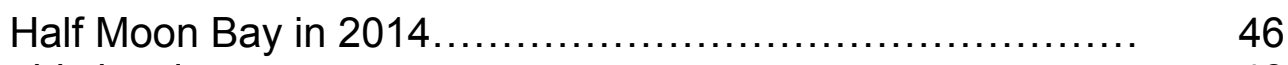

Trophic level................................................. 46

Effects of total length........................................... 49

Determining effects of temporal and spatial factors on diet......... 51

Stable Isotope Analysis............................................ 58

Stable isotope signatures........................................... 59 
Variability in $\delta^{13} \mathrm{C}$ and $\delta^{15} \mathrm{~N}$ based on Total Length, Location, and Year......

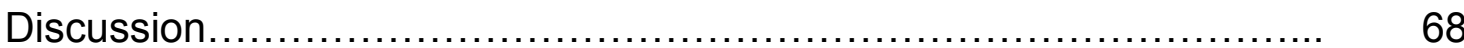

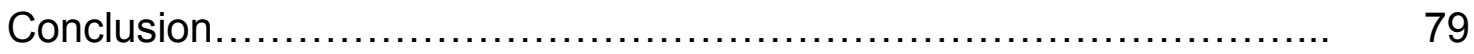

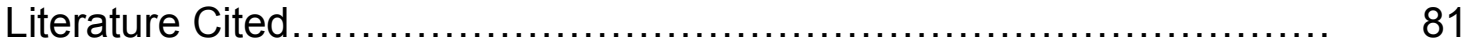

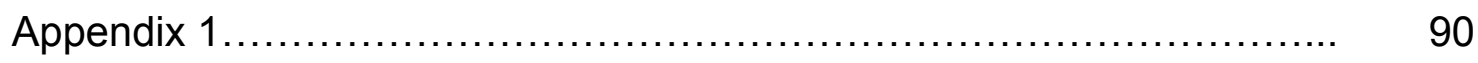




\section{LIST OF TABLES}

Table 1. Distribution of all collected and analyzed Yellowtail Rockfish stomach samples by location and year.

Table 2. Diet composition at the lowest taxonomic level of Yellowtail Rockfish caught at Cordell Bank, the Farallon Islands, and Half Moon Bay in 2013 and 2014 ( $n=251$ stomachs)

Table 3. Presence (shaded) and absence (unshaded) of prey groups at the lowest taxonomic level found in Yellowtail Rockfish (Sebastes flavidus) diets for each location and year.

Table 4. Lowest taxonomic level identifications as determined by gut content analysis, and the associated higher (generalized) categories based on NMFS (2013).

Table 5. Diet composition at the generalized prey level of Yellowtail Rockfish caught at Cordell Bank, the Farallon Islands, and Half Moon Bay in 2013 and 2014 ( $n=251$ stomachs)...................

Table 6. Prey-specific abundance by number (\%PN) and prey-specific abundance by weight (\%PW) of 7 generalized prey categories in the diet of Yellowtail Rockfish at Cordell Bank, the Farallon Islands, and Half Moon Bay in 2013 and 2014. The prey category "Other" was omitted because it occurred so infrequently. Generalized prey categories (Table 2) are listed in alphabetical order. "---" at the Farallon Islands in 2013 indicates no teleosts were found in the stomachs of Yellowtail Rockfish.....

Table 7. Summary of Games-Howell Significant Difference test results for trophic level with p-values to indicate significant differences among location/year combinations....

Table 8. PERMANOVA models of prey composition among several response variables for Yellowtail Rockfish at Cordell Bank, the Farallon Islands, and Half Moon Bay in 2013 and $2014(n=251$ stomachs) 
Table 9. PERMANOVA models of prey composition among several response variables, including Date, for Yellowtail Rockfish at Cordell Bank and the Farallon Islands in 2013 ( $n=74$ stomachs)

Table 10. Summary of results of the overall CCA model by factor for $\% \mathrm{~N}$ and $\% \mathrm{~W}$. Significant factors are in bold text. ...

Table 11. Number of Yellowtail Rockfish white muscle samples included in stable isotope analysis by location and year with associated mean total lengths and standard deviations

Table 12. Means and standard deviations for $\delta^{13} \mathrm{C}(\%), \delta^{15} \mathrm{~N}(\%)$, and C: $\mathrm{N}$ for Yellowtail Rockfish white muscle tissue for all locations and years

Table 13. Summary of Tukey's Honest Significance Difference test results for $\delta^{13} \mathrm{C}$ with $p$-values to indicate signifiant differences among location/year combinations

Table 14. Summary of Tukey's Honest Significance Difference test results for $\delta^{15} \mathrm{~N}$ with $\mathrm{p}$-values to indicate signifiant differences among location/year combinations. 


\section{LIST OF FIGURES}

Figure 1. Rockfish Conservation Area (RCA) project locations where Yellowtail Rockfish (Sebastes flavidus) samples were obtained in Central California...........................................................

Figure 2. Prey accumulation curve for Yellowtail Rockfish caught at Cordell Bank in 2013 at the generalized prey level. Vertical lines represent $95 \%$ confidence intervals around the mean.......

Figure 3. Prey accumulation curve for Yellowtail Rockfish caught at the Farallon Islands 2013 at the generalized prey level. Vertical lines represent $95 \%$ confidence intervals around the mean........

Figure 4. Prey accumulation curve for Yellowtail Rockfish caught at Cordell Bank in 2014 at the generalized prey level. Vertical lines represent $95 \%$ confidence intervals around the mean.......

Figure 5. Prey accumulation curve for Yellowtail Rockfish caught at the Farallon Islands in 2014 at the generalized prey level. Vertical lines represent $95 \%$ confidence intervals around the mean.......

Figure 6. Prey accumulation curve for Yellowtail Rockfish caught at Half Moon Bay in 2014 at the generalized prey level. Vertical lines represent $95 \%$ confidence intervals around the mean..............

Figure 7. Distribution of generalized prey categories for each location and year based on calculated percent prey-specific index of relative importance (\%PSIRI), a metric used to determine the contribution of different prey groups to the overall diet. See Table 4 for prey categories. Abbreviations: COR = Cordell Bank, FAR = Farallon Islands, HMB $=$ Half Moon Bay ..............

Figure 8. Box plot of the trophic level distributions for all locations and years. Bolded line inside each box represents the sample mean. Horizontal lines at the top and bottom of each box represent $+/-1.5 *$ IQR. Open circles denote points that fall outside this range. Abbreviations: $\mathrm{C}=$ Cordell Bank, $\mathrm{F}=$ Farallon Islands, $\mathrm{H}=$ Half Moon Bay, $13=2013,14=2014 \ldots \ldots$. 
Figure 9. Box plot of total length $(\mathrm{cm})$ by location and year. Bolded line inside each box represents the sample mean. Horizontal lines at the top and bottom of each box are represented by $+/-1.5$ * IQR. Open circles denote points that fall outside this range. Abbreviations: $\mathrm{C}=$ Cordell Bank, $\mathrm{F}=$ Farallon Islands, $\mathrm{H}=$ Half Moon Bay, $13=2013,14=2014$.

Figure 10. Trophic levels of female and male Yellowtail Rockfish diets as a function of total length

Figure 11. Yellowtail Rockfish stomach content weight as a function of total length for both sexes combined....

Figure 12. CCA biplot of the relationships between Yellowtail Rockfish stomach samples (black open circles), prey categories (blue triangles), and significant response variables (discrete as squares (red for Location, green for Date), and continuous as orange arrows) based on $\% \mathrm{~N}$ in all locations and years

Figure 13. CCA biplot of the relationships between Yellowtail Rockfish stomach samples (black open circles), prey categories (blue triangles), and significant response variables (discrete as squares (red for Location, green for Date), and continuous as orange arrows) based on \%W in all locations and years

Figure 14. Yellowtail Rockfish total length $(\mathrm{cm})$ as a function of $\delta^{13} \mathrm{C}(\% \circ)$ for all locations and years

Figure 15. Yellowtail Rockfish total length $(\mathrm{cm})$ as a function of $\delta 15 \mathrm{~N}(\%)$ for all locations and years

Figure 16. Box plot of the $\delta^{13} \mathrm{C}$ distributions of Yellowtail Rockfish white muscle tissue for all locations and years. Bolded line inside each box represents the sample mean. Horizontal lines at the top and bottom of each box are represented by $+/-1.5$ * IQR. Open circles denote points that fall outside this range. Abbreviations: $\mathrm{C}=$ Cordell Bank, $\mathrm{F}=$ Farallon Islands, $\mathrm{H}=$ Half Moon Bay, $13=2013,14=2014$ 
Figure 17. Box plot of the $\delta^{15} \mathrm{~N}$ distributions of Yellowtail Rockfish white muscle tissue for all locations and years. Bolded line inside each box represents the sample mean. Horizontal lines at the top and bottom of each box are represented by +/- 1.5 * IQR. Open circles denote points that fall outside this range.

Abbreviations: $\mathrm{C}=$ Cordell Bank, $\mathrm{F}=$ Farallon Islands, $\mathrm{H}=$ Half

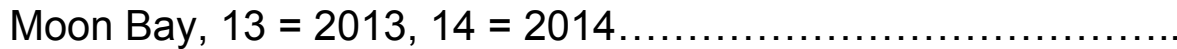

Figure 18. Relationship between Yellowtail Rockfish white muscle $\delta^{13} \mathrm{C}$ and $\delta^{15} \mathrm{~N}$ with standard deviations for all locations and years. Abbreviations: $\mathrm{C}=$ Cordell Bank, $\mathrm{F}=$ Farallon Islands, $\mathrm{H}=$ Half Moon Bay, $13=2013,14=2014$ 


\section{Introduction}

Rocky reef habitats along the continental shelf of California are home to a diverse assemblage of ecologically and economically important species (Allen, Pondella II, \& Horn, 2006). These habitats and species are greatly affected by the California Current Ecosystem (CCE), one of the most productive ecosystems in the world, which is characterized by fluctuations in physical conditions and productivity over multiple temporal scales (Chelton, Bernal, \& McGowan, 1982; McGowan, Cayan, \& Dorman, 1998; Parrish, Nelson, \& Bakun, 1981). Demersal and pelagic rockfishes (Sebastes spp.) are of particular importance to this system. The ecosystem services and contributions these species provide include predator-prey dynamics, nutrient cycling, species diversity, and educational and recreational benefits. Overfishing and climate change are two main drivers of change to rockfish populations, and fishery managers attempt to maintain adequate population sizes and fishery sustainability through a complex set of regulations.

The diets of fishes can be used to evaluate the role of a species in an ecosystem. An investigation of ingested prey items can indicate where a group of individuals have fed, what prey items were consumed, and how these feeding behaviors have varied over time and space (Brown, 2010; Hallacher \& Roberts, 1985; Loury, 2011; Murie, 1995). Species-specific diet analyses can highlight predator-prey relationships (Adams, 1982; Prince \& Gotshall, 1976), reveal broad-scale trophic interactions (Brodeur \& Pearcy, 1984), and define prey 
distributions that can be used in food webs or ecosystem models (Loury, 2011). Also, identifying the geographic and temporal variability in the diet of fishes can fill data gaps and be useful for management. Species-specific information, such as data provided by age, growth, reproduction and diet studies, is critical to building stock assessment models that will yield realistic estimates of the status of a population. Providing a detailed understanding of a single species allows resource managers to confidently piece together the flow of energy through an ecosystem and determine what contributions are lost if that species is overfished.

Stock assessments are conducted by the National Marine Fisheries Service (NMFS) in support of the Pacific Fishery Management Council's (PFMC) evaluation of the abundance and trends of fish stocks, and provide the fundamental basis for management decisions regarding appropriate harvest levels. Stock assessments for some species are conducted annually, whereas other species are evaluated every few years, depending on the status and level of concern. The time between full assessments can be longer than a decade.

Yellowtail Rockfish (Sebastes flavidus) is one species that has not been regularly assessed by the PFMC. The most recent full assessment (Stephens \& Taylor, 2018) came 13 years after this species was last assessed. In the interim, this species was included in a modified review with seven other data-moderate stocks in 2013 (Cope et al., 2015). The PFMC manages two stocks of Yellowtail Rockfish separated at Cape Mendocino, California $\left(40^{\circ} 10^{\prime} \mathrm{N}\right)$. The northern stock is subdivided into three assessment areas (Southern Vancouver from Cape 
Elizabeth $\left(47^{\circ} 20^{\prime} \mathrm{N}\right)$ to approximately $49^{\circ} \mathrm{N}$, Northern Columbia from Cape Falcon $\left(45^{\circ} 46^{\prime} \mathrm{N}\right)$ to Cape Elizabeth $\left(47^{\circ} 20^{\prime} \mathrm{N}\right)$, and Eureka/Southern Columbia from Cape Mendocino $\left(40^{\circ} 30^{\prime} \mathrm{N}\right)$ to Cape Falcon $\left.\left(45^{\circ} 46^{\prime} \mathrm{N}\right)\right)($ Tagart, 1991). All previous assessments have only evaluated the northern stock (Cape Mendocino to $49^{\circ} \mathrm{N}$ ), despite the species' core range extending to Point Conception in Southern California (Eschmeyer, Herald, \& Hamman, 1983; Hart, 1975). In addition to focusing solely on the northern stock, the most recent assessment of Yellowtail Rockfish did not include any information on diet. Different oceanographic conditions, environmental processes, fishing pressures, and prey availabilities in the southern area could lead to different population statuses of the two stocks, and thus leading to misinformed management. Studies conducted over large spatial scales can be useful for detecting general trends, but may create too broad of a scope that could lead to oversight of important nuances in trophic ecology. According to the most recent stock assessment, the main reason the southern stock model was not sufficiently robust for management purposes was primarily due to lack of data (Stephens and Taylor, 2018).

In most cases, single-species assessments use statistical population models to integrate and analyze survey, fishery, and biological data (Pacific Fishery Management Council [PFMC], 2016). Current modeling using the single-species approach, however, generally neglects the importance of the temporal and spatial availability of key prey species (Ainley, Adams, \& Jahncke, 2014). A 
study by Field and Francis (2006) concluded that fishery management should be a combination of a single-species approach and a truly holistic ecosystem perspective. Fisheries management of the CCE must take into account the constantly changing climate-driven physical and biological interactions in the ecosystem, the trophic relationships between fished and unfished components of the food web, the life history diversity due to adaptation, and the role of humans as predators and competitors (Field \& Francis, 2006). Ideally, complete information regarding ocean conditions, productivity, prey availability, and other measures of ecological health, would be available to be integrated into ecosystem models. This ecosystem-based fisheries management approach, however, is only strong if the single-species information utilized in modeling is accurate and current.

Stable isotope analysis (SIA) is a method, complimentary to gut analysis, for evaluating trophic relationships. SIA integrates the chemical signature of prey items that have been eaten over periods of time in excess of the gut residence time of the predator (i.e., weeks to months) (Melville \& Connolly, 2003). A comparison of the ratios of stable isotopes of nitrogen $\left(\delta^{15} \mathrm{~N}\right)$ and carbon $\left(\delta^{13} \mathrm{C}\right)$ in tissues provides an estimate of trophic position and nutrient flow from producers in food webs (Post, 2002). The heavier ${ }^{15} \mathrm{~N}$ isotope is often sequestered in tissues over the lighter ${ }^{14} \mathrm{~N}$, due to a process called fractionation, and thus predators at increasingly higher trophic levels are typically enriched in ${ }^{15} \mathrm{~N}$ relative to ${ }^{14} \mathrm{~N}$ (i.e., higher $\delta^{15} \mathrm{~N}$ ). The ratio of ${ }^{13} \mathrm{C} /{ }^{12} \mathrm{C}$ changes minimally as 
carbon moves through the food web, and therefore can reflect the sources of dietary carbon when the isotopic signatures of the sources are different (Post, 2002). For example, in terrestrial systems, $\delta^{13} \mathrm{C}$ can be used to differentiate between diets comprised of plants from different photosynthetic pathways (i.e., $\mathrm{C}_{3}$ vs. $\mathrm{C}_{4}$ ) (O'Leary, Madhaven, \& Paneth, 1992; Peterson \& Fry, 1987; Rounick \& Winterbourn, 1986). In aquatic systems, $\delta^{13} \mathrm{C}$ can be distinguish between two major sources of available energy, littoral (nearshore) and pelagic (open water) production, because the $\delta^{13} \mathrm{C}$ of the base of the littoral food web tends to be enriched in ${ }^{13} \mathrm{C}$ relative to the base of the pelagic food web (France, 1995). SIA has become a prominent tool in ecology, and has been combined with the traditional method of diet analysis to more effectively clarify trophic dynamics (Bearhop, Adams, Waldron, Fuller, \& Macleod, 2004; Davis, Blanchette, Pusey, Jardine, \& Pearson, 2012; Hussey, Dudley, McCarthy, Cliff, \& Fisk, 2011).

The goal of my research was to use multiple techniques to investigate the spatial and temporal variability of Yellowtail Rockfish diets in central California. This study was divided into two main parts, a) gut content analysis and b) stable isotope analysis. This separation allowed me to address the following objectives: 1) Identify gut contents of Yellowtail Rockfish, 2) Describe diversity in Yellowtail Rockfish diets over space and time, 3) Identify stable isotope signatures in white muscle tissue of Yellowtail Rockfish, and 4) Compare stable isotope ratios with the gut content analysis and evaluate the factors influencing variability in ingested prey items. 


\section{Background}

\section{Gut Content Analysis}

Hyslop (1980) described five common methods for conducting diet analyses, based on work published by Hynes (1950), Windell (1968), and Windell \& Bowen (1978). These five methods are: (1) the frequency of occurrence method, (2) the numerical method, (3) the volumetric method, (4) the gravimetric method, and (5) the subjective method. There is no one method that gives a complete picture of dietary contribution and importance. Instead, methods used vary based on the questions being asked and the species selected.

In a study of gut contents among a multitude of individuals sampled, the frequency of occurrence method is the simplest method used to compare diets and involves recording the number of stomachs containing one or more individuals of each food category. It provides a qualitative analysis of diet composition, but gives little indication of the relative amount of each food category in the stomach. The numerical method differs in that the number of individuals of each food category is recorded for all stomachs and expressed as a proportion of the total individuals in all food categories. This method is effective if prey items are easily identified. It does not take into account fish size or items that cannot be enumerated. In addition, this method can overemphasize the importance of small prey items taken in large numbers or those prey items that digest more slowly. The volumetric method involves the calculation of the volume of prey items in a gut sample. This is usually assessed by measuring the 
displacement of each food item or group of items in a graduated measuring device. The total volume of a food category is typically given as a percentage of the total volume of all stomach contents. In the gravimetric method, the wet or dry weights of food categories are measured. The total weight of a food category can be expressed as a percentage of the overall weight of stomach contents. The contribution of rare heavy items is disproportionately represented using this method, which can skew the visual perception of the organism's diet. However, it is crucial to understand that a single large prey item can be more important and can energetically contribute more to a predator's diet than numerous small prey items. The last approach used to compare diets is the subjective method. Each food category is awarded points that are qualitatively assigned based upon their estimated contribution to the volume of a stomach. Estimates of stomach fullness and digestion are also incorporated.

Some techniques for analyzing diets combine several of these methods into one index. One of these is the index of relative importance (IRI), in which the percent frequency of occurrence of each prey category is multiplied by the sum of the percent volume (or weight) and the percent number to cancel out biases of individual components (Bigg \& Perez, 1985). Brown (2010) and Brown et al. (2012) modified this index to be prey-specific (PSIRI) so that it was less biased, a better overall index for prey contribution to a diet, and could be additive with respect to taxonomic levels. 


\section{Stable Isotope Analysis}

Stable isotopes are atoms of elements that have different numbers of neutrons, but do not undergo radioactive decay (Meier-Augenstein \& Kemp, 2012). Because of the differences in mass, those isotopes are differentially incorporated into biological tissues, at rates that can be estimated, based on statistical probability. In trophic studies, isotopic fractionation was first used to investigate the foraging ecology of animals in the 1970s. The abundance of different isotopes in tissues has informed our understanding of trophic ecology through the comparison of predator tissues with ingested prey items (Hopkins \& Ferguson, 2012). Stable isotope ratios reflect the combined effects of metabolism in the turnover of existing tissues - where isotopic turnover is defined as the time it takes for a given consumer tissue to reflect the isotopic composition of new food resources - as a result of growth and tissue replacement (Madigan et al., 2012), tissue protein composition (the association of stable isotope signatures with specific amino acids) and diet (what an animal is consuming), with different tissues in the body combining these effects in different ways (MacNeil, Skomal, \& Fisk, 2005).

Carbon isotopes change minimally as carbon moves through the food web, yet primary producers using different photosynthetic pathways are isotopically distinct (e.g., phytoplankton vs. macroalgae), and $\delta^{13} \mathrm{C}$ can therefore serve as a tracer of an organism's source of dietary carbon (Post, 2002). The appropriate fractionation in $\delta^{13} \mathrm{C}$ is still debated, despite its widespread use in stable isotope 
research. These values range from $0 \%$ (Peterson \& Fry, 1987) to $1 \% 0$ (DeNiro \& Epstein, 1978; Fry \& Arnold, 1982). Post (2002) found a mean change in $\delta^{13} \mathrm{C}$ of $0.39 \pm 1.3 \%$ ( $\pm 1 \mathrm{sd})$ in a review of $107 \Delta \delta^{13} \mathrm{C}$ estimates. However, a study by Sweeting et al. (2007) provided evidence for the use of $\Delta \delta^{13} \mathrm{C}$ estimates of $1.5 \%$ per trophic step for fish as a better approximation to bulk $\Delta \delta^{13} \mathrm{C}$ than previously applied values of $\leq 1 \%$.

Nitrogen isotopes can provide an indicator of an organism's trophic position because enrichment in $\delta^{15} \mathrm{~N}$ of $2.5 \%$ to $4.0 \%$ is typically observed from prey to consumer (Perkins et al., 2014; Post, 2002). $\delta^{15} \mathrm{~N}$ is transferred from prey to predators (i.e., trophic discrimination), and thus organisms higher in the trophic pyramid have accumulated higher levels of $\delta^{15} \mathrm{~N}$. Preliminary data indicate that Yellowtail Rockfish along the California coast have values of $\delta^{13} \mathrm{C}$ varying from -18.5 to -16 , and values of $\delta^{15} \mathrm{~N}$ ranging from 13.5 to 15.5 (Jennifer Chiu, Moss Landing Marine Laboratories, unpublished data 2015).

Gut contents provide information on the most recent meal consumed, which may or may not be reflective of the dietary habitats of a species over the long term. In contrast, stable isotope signatures provide information on an organism's patterns of prey consumption over a longer period of time than is obtained through a gut content analysis alone. Depending on the turnover time of different tissues, isotopic signatures can integrate dietary information over scales ranging from days (e.g., blood) to years (e.g., bone and spines). In fish, for instance, muscle tissue integrates diet over several weeks to many months (Boecklen, 
Yarnes, Cook, \& James, 2011; Hesslein, Hallard, \& Ramlal, 1993). Muscle tissue is less metabolically active than blood or liver tissue (MacNeil et al., 2005), which increases the time over which isotopic signatures of specific prey items can be detected. Combining stable isotope analysis of muscle tissue and gut content analysis can create a more cohesive picture of what the organism was consuming on both short and long time scales.

\section{Study Species}

The Yellowtail Rockfish is a mid-water species that is abundant from central California to Alaska (Love, 2011). Yellowtail Rockfish typically inhabit coastal waters between depths of $90-180 \mathrm{~m}$, but have been found to a depth of $549 \mathrm{~m}$. Maximum length, weight, and age are $66 \mathrm{~cm}$ total length (TL), $4.2 \mathrm{~kg}$, and 64 years, respectively (Love, 2011). After spending about three and a half months in the plankton, juvenile Yellowtail Rockfish usually recruit to nearshore waters and settle among kelp and other algae from April through August. They can settle as small as $2.8 \mathrm{~cm}$ standard length, but have also been found to stay in the water column until they are $6.3 \mathrm{~cm}$ standard length (Love, 2011). Their preferred habitat is over high relief, rocky areas where they tend to school in the water

column. As Yellowtail Rockfish mature, they generally migrate to deeper waters. Unlike most other rockfishes, Yellowtail Rockfish often make extensive, rapid, frequent ascents and descents in the water column (Love, 2011).

The diet of Yellowtail Rockfish consists of a diverse range of planktonic and micronektonic prey items (Brodeur \& Pearcy, 1984; Lee \& Sampson, 2009; 
Rosenthal, Moran-O'Connell, \& Murphy, 1988). Previous diet studies of Yellowtail Rockfish in waters off the coast of Oregon, Washington and Alaska indicate that euphausiids typically dominate the diet in terms of frequency of occurrence and percent by number. Hyperiid amphipods, decapods, and cephalopods were also represented, but were not as numerous and did not comprise a major portion of the diet with respect to weight. Seasonal occurrences of copepods, larval decapods, and gelatinous zooplankton were also common. Fishes, predominately mesopelagic species and juvenile stages of benthic species, were an important component on a weight basis.

Several researchers have correlated environmental conditions to pelagic juvenile abundance and juvenile recruitment of rockfishes, including Yellowtail Rockfish. Year-class strength is particularly impacted during early larval phase, and annual pelagic juvenile abundance is strongly correlated with physical conditions, especially upwelling strength along the coast (Field \& Ralston, 2005; Laidig, 2010; Laidig, Chess, \& Howard, 2007; Ralston \& Stewart, 2013).

Females tend to grow faster than males, and Yellowtail Rockfish off Washington and Oregon grow faster than those off California, leading to variations in their size at first maturity (Love, 2011). Size at 50\% maturity for males is $32-44 \mathrm{~cm} \mathrm{TL}$, and $36-54 \mathrm{~cm}$ TL for females. Females produce between 56,000 and 2 million eggs, and release larvae between January and July (Love, 2011). 
Yellowtail Rockfish were one of the more commonly caught commercial rockfish species in the late 20th century. Between 1983 and 1998, Yellowtail Rockfish accounted for $13 \%$ of all rockfishes landed on the U.S. West Coast, and $6 \%$ of all groundfish, excluding Pacific Whiting (Merluccius productus). The only rockfish species with a greater west coast harvest was the Widow Rockfish (Sebastes entomelas). In California waters, the total combined landings among all Yellowtail Rockfish fisheries between 1980 and 1998 ranged from 370 to 2,460 tons per year (TPY), averaging 1,080 TPY over that period. The fishery experienced ebbs and flows with catches exceeding 2,200 TPY during 1982 and 1983, declining to 550 TPY through 1998, rising above 1,100 TPY from 1989 to 1992, and then falling again to approximately 550 TPY in the years thereafter (Ralston 2001). The spawning output for the northern stock was estimated to have fallen below $40 \%$ of unfished equilibrium in the early 1980 s, to a minimum of $29.3 \%$ in 1984 , but then rebounded to $75.2 \%$ in 2017 (Stephens \& Taylor, 2018).

In recent years, the recreational fishery has been responsible for about one-third of all landings of Yellowtail Rockfish catch in California. In the commercial sector, trawl fishing has produced $28 \%$ of total landings, with hookand-line and set-net fisheries following behind at $24 \%$ and $13 \%$ of all landings, respectively. With the exception of Bocaccio (Sebastes paucispinis), Yellowtail Rockfish have been the most harvested species by all California groundfish fisheries (Ralston, 2001). 
Yellowtail Rockfish have been found to co-occur with other species such as Canary Rockfish (Sebastes pinniger) and Widow Rockfish (Nagtegaal, 1983; Rogers \& Pikitch, 1992; Tagart, 1987). In 2000, the Pacific Fisheries Management Council (PFMC) implemented stringent management measures to reduce the catch of Canary Rockfish, thus limiting not only their harvest, but also catches of co-occurring species. The association with these recovering species that have been, or continue to be, declared overfished has greatly altered fishing opportunity for Yellowtail Rockfish (Wallace \& Lai, 2005). 


\section{Materials and Methods}

\section{Study Area}

Rockfish Conservation Areas (RCAs) are large-scale areas of the continental shelf and slope along the west coast of the United States that are closed to specific recreational and commercial fishing activities. In 2002, the Pacific Fishery Management Council established these spatial closures in an effort to rebuild and protect overfished species. The general boundaries of the RCAs are based on depth contours, but the precise boundaries have varied by season and year, gear type used, and latitude (Marks et al., 2015).

Yellowtail Rockfish for this research were collected as part of a fisheriesindependent project designed to evaluate abundances of fishes inside RCAs that had been closed for over ten years (Marks et al., 2015). Specimens were obtained from three central California locations: Cordell Bank $\left(38^{\circ} 0^{\prime} \mathrm{N}-38^{\circ} 5^{\prime} \mathrm{N}\right.$, $\left.123^{\circ} 24^{\prime} \mathrm{W}-123^{\circ} 28^{\prime} \mathrm{W}\right)$, Farallon Islands $\left(37^{\circ} 42^{\prime} \mathrm{N}-37^{\circ} 44^{\prime} \mathrm{N}, 123^{\circ} 1^{\prime} \mathrm{W}-123^{\circ}\right.$ $\left.5^{\prime} \mathrm{W}\right)$, and Half Moon Bay $\left(37^{\circ} 17^{\prime} \mathrm{N}-37^{\circ} 23^{\prime} \mathrm{N}, 122^{\circ} 35^{\prime} \mathrm{W}-122^{\circ} 38^{\prime} \mathrm{W}\right)$ (Figure 1). The Cordell Bank sites were located about $40 \mathrm{~km}$ west of Point Reyes and were mainly comprised of high relief rocky habitats, including some pinnacles that could reach $35 \mathrm{~m}$ below the surface. The Farallon Islands sites were approximately $50 \mathrm{~km}$ west of San Francisco and were split between the North Farallon Island and Southeast Farallon Island. The Half Moon Bay sites were between 4 and $20 \mathrm{~km}$ offshore and included low relief, rocky habitat (Marks et al., 
2015). Fish were caught at depths ranging from 37 to $168 \mathrm{~m}$, with a mean depth of $73 \mathrm{~m}$.

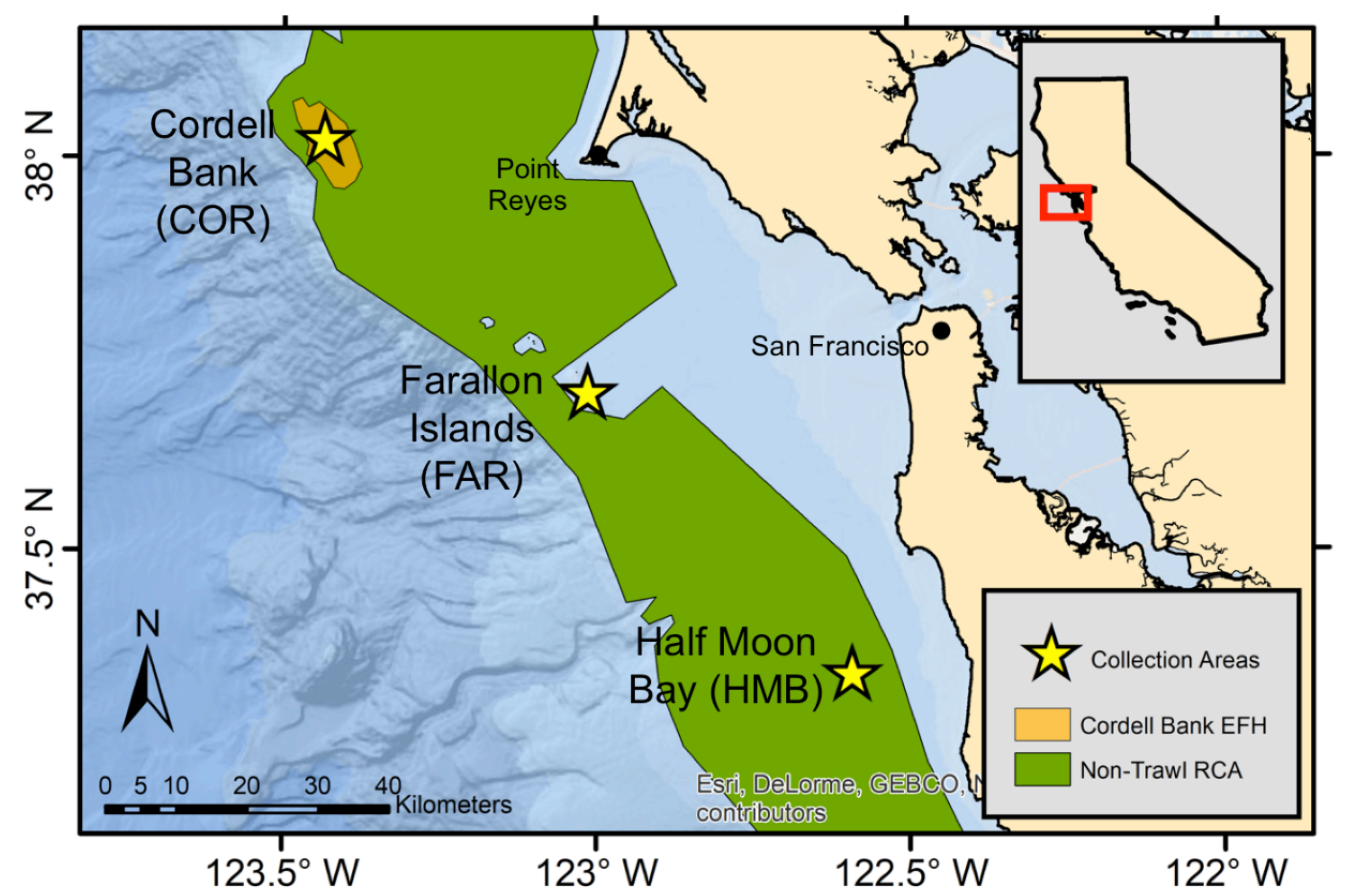

Figure 1. Rockfish Conservation Area (RCA) project locations where Yellowtail Rockfish (Sebastes flavidus) samples were obtained in Central California. 


\section{Sample Collection}

The most common species caught on the RCA Project sampling trips were Yellowtail Rockfish, Blue Rockfish (S. mystinus), Canary Rockfish, Widow Rockfish, Rosy Rockfish (S. rosaceus), and Lingcod (Ophiodon elongatus). A primary result from the project was that catch rates were higher inside RCAs than outside RCAs, largely in part due to Yellowtail Rockfish comprising the majority of the catch. Fishes were collected and retained for a variety of different studies, including fecundity, age and growth, and dietary analysis.

All specimens were caught via hook-and-line at each of the three locations between August and October of 2013 and 2014. In 2013, Cordell Bank was sampled on September 9, 10, and 11, and the Farallon Islands were sampled on August 29 and 30, and October 15. In 2014, Cordell Bank was sampled on October 23, the Farallon Islands was sampled on August 21, and Half Moon Bay was sampled on August 13. These specimens were acquired from NMFS under their National Oceanic and Atmospheric Administration (NOAA) Scientific Research Permits SRP-22-2013 and SRP-22-2014, and San Jose State University (SJSU) Institutional Animal Care and Use Committee (IACUC) protocol \#2015-B.

Any fish exhibiting stomach eversion was not retained. Aboard the fishing vessel, each fish was measured to the nearest half centimeter, observed for condition, and given a tag with a unique 5-digit number. Captured Yellowtail Rockfish were euthanized according to IACUC protocols and placed in 100-quart 
coolers with ice for transit back to the harbor. Fish were kept on ice and stomachs and tissue samples were removed within 24 hours of capture at the NMFS Southwest Fisheries Science Center in Santa Cruz, CA. The removed stomachs were placed in Nasco Whirl-Paks and tissue samples were placed in cryovials. All samples were labeled with a unique identification number and stored in the $0-4^{\circ} \mathrm{C}$ walk-in freezer at MLML. Those whole specimens that were not processed at NMFS were placed in the freezer at MLML for processing at a later date.

\section{Gut Content Analysis}

Dissections. Whole, frozen specimens were thawed prior to the removal of the stomach and tissue samples at MLML. Stomachs were snipped as close to the pyloric caeca junction as possible with care taken to ensure that no contents were lost (Murie, 1995). The removed stomach was placed in Nasco Whirl-Pak and annotated with the fish's unique identification number. All samples were placed back in the freezer until further analysis could be conducted (i.e., stomachs for gut content analysis and tissues for stable isotope analysis).

Describing stomach contents. Yellowtail Rockfish stomachs were pulled from the freezer and thawed until they were soft enough to cut open. This took approximately 30 minutes to 1 hour, depending on the size and fullness of the stomach. Each whole stomach was blotted dry with a paper towel and weighed to the nearest $1 \mathrm{mg}$, as were the stomach linings and bulk stomach contents. Once all stomachs were removed from the body cavities, I examined the gut 
contents and identified prey items to the lowest visual taxonomic level. Empty stomachs, or those containing only liquids and solids that were too digested to identify, were not included in the data analyses.

Prey items were separated, enumerated, and weighed to the nearest $\mathrm{mg}$. Prey items were identified to the lowest possible taxonomic level using a variety of taxonomic keys (Carlton, 2007; Miller \& Lea, 1972, Morris, Abbott, \& Haderlie, 1980) as well as through personal correspondence with local invertebrate and fish experts (S. Kim, V. Loeb, D. Kline, \& P. Slattery, personal communications, July 2016). Large prey items, such as fish, were removed first, and any paired parts that were more resistant to digestion (i.e., otoliths and eye balls) were counted and halved to determine the minimum counts of prey ingested (Brodeur \& Pearcy, 1984). Debris (such as rocks) and parasites that were attached to the stomach lining were discarded. Bait used to catch fish (mantles of cut Market Squid, Doryteuthis opalescens) was easily identifiable in stomachs and excluded from future analyses. The number of crustacean individuals consumed was determined by counting the total number of carapaces (Murie, 1995).

The importance of food items and their contribution to the diet were evaluated using the following metrics: average percent number (\%N, Hyslop, 1980), average percent weight (\%W, Hyslop, 1980), prey-specific number (\%PN, Amundsen, Gabler, \& Staldvik, 1996; Brown, Bizzarro, Cailliet, \& Ebert, 2012), prey-specific weight (\%PW, Amundsen et al., 1996, Brown et al., 2012), and frequency of occurrence (\%FO, Hyslop, 1980). 
Average percent number and weight $(\% \mathrm{~N}$ and $\% \mathrm{~W})$ were calculated for each stomach as follows:

$$
\% A_{i}=\frac{\sum_{j=1}^{n} A_{i j}}{n}
$$

where $A_{i j}$ is the abundance by percent number or weight for prey $i$ and individual stomach samples $j$, and $n$ is the number of total stomachs containing prey.

Prey-specific number and weight (\%PN and \%PW) were calculated as follows:

$$
\% P A_{i}=\frac{\sum_{j=1}^{n} A_{i j}}{n_{i}}
$$

where $A_{i j}$ is the abundance by percent number or weight for prey $i$ and individual stomach samples $j$, and $n_{i}$ is the number of stomachs with prey $i$. Prey-specific abundance by number (\%PN) and prey-specific abundance by weight (\%PW) were compared because singling out one metric could bias results. There are typically fewer large, heavy prey items (i.e., Teleosts or Squid), and more smaller, lighter prey items (i.e., Salps or Euphausiids) in a stomach. If the calculations for \%PN and \%PW are not significantly different, one can be treated as a proxy for the other and analyses can be performed on one metric. However, if results are significantly different, analyzing both metrics provides a more complete picture of diet composition.

Frequency of occurrence (\%FO) was calculated as follows:

$$
\% F O=\frac{n_{i}}{n} * 100
$$


where $n_{i}$ is the number of stomachs containing prey $i$, and $n$ is the total number of stomachs containing prey.

The Index of Relative Importance (IRI; Pinkas, Oliphant, \& Iverson, 1971) has been used to measure the overall contribution of prey groups to a species overall diet by combining $\% \mathrm{~N}, \% \mathrm{~W}$, and $\% \mathrm{FO}$, such that:

$$
I R I_{i}=\left(\% N_{i}+\% W_{i}\right) * \% F O
$$

However, because $\% \mathrm{~N}$ and $\% \mathrm{~W}$ are already compound indices as a result of multiplying prey-specific abundance values by $\% \mathrm{FO}$, combining average abundance values with \%FO in the IRI is redundant and grossly overemphasizes \%FO (Brown et al., 2012). Therefore, I used a modified prey-specific IRI (PSIRI) following Brown et al. (2012):

$$
P S I R I_{i}=\left(\% P N_{i}+\% P W_{i}\right) * \% F O
$$

This metric is less biased and a better overall index of diet composition than \%IRI. In addition, \%PSIRI is additive with respect to taxonomic levels. The sum of \%PSIRI for a group of species under a family equals the \%PSIRI for that family, thus making the results of \%PSIRI more comparable within and among species and across studies than \%IRI (Brown et al., 2012).

Sample size sufficiency. The number of unique prey categories was plotted as a function of the number of stomachs analyzed to determine if enough stomach samples were collected to adequately describe the diet of Yellowtail Rockfish in each year and location (Ferry \& Cailliet, 1996). Both the lowest level of taxonomic identification and the higher (generalized) taxonomic distinctions 
established by the Groundfish Essential Fish Habitat Synthesis Team (National Marine Fisheries Service [NMFS], 2013) were used to determine sample size sufficiency. Prey items at the lowest taxonomic levels were combined into higher (generalized) taxonomic distinctions (NMFS, 2013) because calculating diet metrics at the generalized prey level can often be more useful for species with variable diets, numerous rare prey items, or a large proportion of items that cannot be identified to lower taxonomic levels. Polychaetes, gastropods, and isopods were rare prey items in Yellowtail Rockfish stomachs, thus I grouped them together into an "Other" prey category for the generalized distinctions. Cumulative prey curves were plotted using the software program $R$ (v. 3.3.2) and the Vegan Community Ecology package (Oksanen et al., 2013). As sample sizes increase, the variation in diet should decrease because new prey items are introduced into the diet less frequently. Therefore, once the curve reached an asymptote, I assumed that enough samples had been analyzed to adequately describe the diet composition (Ferry \& Cailliet, 1996). I performed a linear regression using the last five points of the curve to test for adequate sample size and determine if the curve had reached an asymptote (Bizzarro, Robinson, Rinewalt, \& Ebert, 2007; Bizzarro, Smith, Márquez-Farías, Tyminski, \& Hueter, 2009). If the slope $(b)$ of the linear regression was $\leq 0.05)$, the curve was considered to have reached an asymptote (Bigman, 2013; Bizzarro et al., 2009; Kemper, 2012; Kemper, Bizzarro, \& Ebert, 2017). 
Trophic level. The trophic levels of individual Yellowtail Rockfish were determined from the stomach contents following techniques described by Cortés (1997):

$$
T L_{k}=1+\left(\sum_{j=1}^{n} P_{j} * T L_{j}\right)
$$

where $T L_{k}$ is the trophic level of species $k, P_{j}$ is the proportion of prey category $j$ in the diet of species $k, n$ is the total number of prey categories, and $T L_{j}$ is the trophic level of prey category $j$. Trophic levels were assigned based on categories described by Ebert and Bizzarro (2007).

The data related to trophic level by location and year were not normally distributed, and therefore did not meet the assumptions for an ANOVA. Instead, a Kuskall-Wallis test was used to determine if the distributions were significantly different. The Games-Howell post-hoc test, similar to Tukey's Honest Significant Difference Test, was used as a nonparametric approach to determine among which groups the significance lies.

Determining effects of temporal and spatial factors on diet. Prey data at the lowest taxonomic level were regrouped into higher (generalized) prey categories to evaluate two commonly used diet metrics. The combination of prey groups reduced redundancy amongst prey categories and minimized the contribution of rare prey groups that could have biased results, while still maintaining variability in the diets (Legendre \& Gallagher, 2001). Two individualbased abundance estimates, percentage by number $(\% \mathrm{~N})$ and percentage by 
weight $(\% \mathrm{~W})$, were calculated for Yellowtail Rockfish at each location and year. Numerical data are typically associated with feeding behavior, whereas weight data are considered a proxy for energetic value (Hyslop, 1980). To test for redundancy, both metrics were compared at the generalized prey category level using linear regression to evaluate variability between the datasets. Because all locations and years displayed significant differences $(P<0.05)$ in the best-fit linear models, both metrics were used in the analyses moving forward.

Permutational multivariate analysis of variance (PERMANOVA) is an approach used to compare two or more groups in multivariate space (Anderson, 2001). PERMANOVA analysis was used to determine which response variables, or combination of response variables, best explained the variability seen in the diet data of Yellowtail Rockfish. The Bray-Curtis dissimilarity index was used as the basis for matrix calculations and the PERMANOVA model was permuted 9999 times (Bray \& Curtis, 1957). All multivariate analyses were conducted in R (v. 3.3.2) using the vegan package (Oksanen et al., 2013).

The explanatory variables used in the PERMANOVA were Location, Year, Depth, Sex, and Length. To establish the best overall model, individual models for each variable were tested for significance and explained variance. This resulted in five single factor models. The interaction term of Location $\mathrm{x}$ Year was tested based on the results from the individual models and to combine a spatial and temporal variable. For both independent variables and interaction terms, significant factors were ranked by their $r^{2}$ values and one by one added to the 
final model. The order of terms matters in PERMANOVA models, hence the use of this ranking system for variables. When a factor no longer increased the $r^{2}$ value and/or was not significant, additions ceased and the final model was established.

Beta diversity can be defined as the variability in species composition among sampling units for a given area (Anderson, Ellingsen, \& McArdle, 2006). Multivariate homogeneity of group dispersions can be tested using the vegan package in $\mathrm{R}$ with the betadisper() function. Each explanatory variable was evaluated using a permutational approach, and a significant result indicates that there is significant variability within that factor (i.e., if Location showed a significant beta dispersion result, there is inherent variability within Locations that could be influencing the overall variability expressed by the model).

A second PERMANOVA was performed to test for the effect of Date on the variability seen in Yellowtail Rockfish diets. Date is a variable that can show if diets are significantly changing over time scales finer than a year. Cordell Bank 2013 and Farallon Islands 2013 were subsampled for this analysis since multiple fishing days occurred at these Location/Year combinations. Other variables tested included Location, Length, Depth, Sex, and the interaction term Date $\mathrm{x}$ Location.

Canonical methods were used to determine the structure, or correspondence, between two sets of variables (matrices) measured on the same sampling units (Legendre \& Legendre, 1998). Canonical correspondence analysis (CCA) uses 
multiple regression techniques to obtain linear combinations of the predictor variables that best explain sampling unit positions in species space (ter Braak \& Smilauer, 2002). CCA assumes species responses are unimodal and predictor data are linear. CCA was performed on the same datasets to supplement the results of the PERMANOVA, and determined the degree of the relationship between diet data and response variables. Significance of the overall model, each canonical axis, and each response variable was determined by 9999 permutations. For each, a biplot of significant response variables and prey categorizations along the first two canonical axes was created for visual interpretation (Kemper, 2017). Length and direction of arrows indicate the relative amount of dietary availability explained by each variable on each canonical axis, and the spatial association of each response variable and prey category indicates the strength of their relationships.

\section{Stable Isotope Analysis}

Sample preparation. After removing the stomachs from the collected Yellowtail Rockfish from Cordell Bank, the Farallon Islands, and Half Moon Bay in 2013 and 2014, tissue samples were extracted for stable isotope analysis. A sample of white muscle tissue was taken just below the dorsal fin for each fish, placed in a $1.8 \mathrm{~mL}$ twist-top cryovial, and frozen in the $0-4^{\circ} \mathrm{C}$ walk-in freezer at MLML. Samples were lyophilized at the Marine Analytical Laboratory in the Earth and Marine Science Building at UC Santa Cruz. Tops of cryovials were loosened to allow adequate airflow during the drying process and loaded into 
plastic desiccators connected to the Labconco Corporation FreeZone 4.5 liter Benchtop Freeze Dry System. Samples were left to lyophilize for 48 hours, or until it was clear the tissues were fully dried.

Each sample was ground into a fine powder using a glass mortar and pestle. Samples were stored alongside color-indicating Drierite to prevent moisture from returning to the dried samples. Pressed tin capsules (EA Consumables, $6 \times 4$ $\mathrm{mm}$ ) were filled with $0.45-0.55 \mathrm{mg}$ of powdered tissue and loaded into 96 well plastic trays. Sample weights were measured on the Perkin-Elmer AD2Z Autobalance in the Trace Metals Laboratory at MLML. Carefully packed trays of samples were sent to the Stable Isotope Laboratory in Idaho State University (ISU)'s Department of Geosciences for analysis. Samples were analyzed using an ECS 4010 (Elemental Combustion System 4010) interfaced with a Delta V Advantage mass spectrometer through the COnFlo IV system at ISU. Four inhouse standards (ISU Peptone, Costech Acetanilide, DORM-3, and ISU Glycine) were used to directly calibrate against international standards.

Delta notation. In most ecological studies, results from the stable isotope analysis are reported using the delta $(\bar{\delta})$ notation, which are parts per thousand differences from a standard:

$$
\delta X=\left[\frac{R_{\text {sample }}}{R_{\text {standard }}}-1\right] \times 1000
$$

where $X$ is ${ }^{13} \mathrm{C}$ or ${ }^{15} \mathrm{~N}, R_{\text {sample }}$ is the corresponding ratio ${ }^{13} \mathrm{C} /{ }^{12} \mathrm{C}$ or ${ }^{15} \mathrm{~N} /{ }^{14} \mathrm{~N}$, and $R_{\text {standard }}$ is the isotope ratio for the international reference standard (PeeDee limestone for carbon and atmospheric nitrogen gas for nitrogen). The result is 
multiplied by 1000 to amplify small differences measured between samples and standards. The $\delta$ value that results has the units of permil (\%o), from the Latin root parts per thousand, which makes small neutron-related isotope differences seem large. For example, a sample that measures $10 \%$ is only $1 \%$ different than the standard. A positive $\delta$ value can be interpreted to mean that the sample has a higher abundance of the heavier isotope compared to the international reference standard used, while a negative $\delta$ value means the sample has a lower abundance of the heavier isotope than the international reference standard (Peterson \& Fry, 1987).

$\delta^{13} \mathrm{C}$ correction. A weight ratio of $\mathrm{C}$ to $\mathrm{N}$ was calculated based on the percentages of $\mathrm{C}$ and $\mathrm{N}$ in each sample, which is commonly used as a proxy for lipid content. Biases to the $\delta^{13} \mathrm{C}$ could be introduced if lipid content is too high. A common benchmark for this measurement is when a tissue sample has greater than $5 \%$ lipid content, or the $\mathrm{C}: \mathrm{N}$ weight ratio is higher than 3.5 . If this threshold is exceeded, the lipid content in a sample can be corrected chemically or by applying a mathematical equation (Post et al., 2007).

Variability in $\delta^{13} \mathrm{C}$ and $\delta^{15} \mathrm{~N}$ based on total length, location and year. Relationships between $\delta^{13} \mathrm{C}$ and $\delta^{15} \mathrm{~N}$ were evaluated with respect to total length, location and year to determine if these factors were significant drivers of variability. A linear regression was performed to evaluate the relationship between total length and $\delta^{13} \mathrm{C}$, and between total length and $\delta^{15} \mathrm{~N}$. Relationships established between total length and $\delta^{13} \mathrm{C}$ or $\delta^{15} \mathrm{~N}$ could indicate ontogenetic 
shifts, or trends with feeding as Yellowtail Rockfish are changing sizes. An analysis of variance (ANOVA) was used to determine the effects of location and year on $\delta^{13} \mathrm{C}$ and $\delta^{15} \mathrm{~N}$, by comparing multiple means across different groups. Tukey's Honest Significant Difference test was used as a post-hoc test to determine which locations and years were driving the significance. 


\section{Results}

\section{Gut Content Analysis}

A total of 433 Yellowtail Rockfish were collected across 2 years and 3 locations (Table 1). Of the 433 fish collected, $182(42 \%)$ had empty stomachs, or stomachs containing only unknown solids and liquids. Therefore, diets were analyzed for the remaining 251 fish. These 251 fish consisted of 97 males (38.7\%) and 105 females (41.8\%). There were 49 fish of unknown sex (19.5\%) because sex data were not recorded during those dissections. Total lengths of fish collected from all years and locations ranged from $22-48 \mathrm{~cm}$, with a mean of $33.1 \mathrm{~cm}$.

\section{Table 1}

Distribution of all collected and analyzed Yellowtail Rockfish stomach samples by location and year.

\begin{tabular}{c|ccc}
\hline Location/Year & $\begin{array}{c}\text { Total \# of } \\
\text { Stomachs }\end{array}$ & $\begin{array}{c}\text { \# of Stomachs } \\
\text { with Contents }\end{array}$ & $\begin{array}{c}\text { \% of Stomachs } \\
\text { with Contents }\end{array}$ \\
\hline Cordell Bank 2013 & 40 & 33 & 82.5 \\
Farallon Islands 2013 & 56 & 41 & 73.2 \\
Cordell Bank 2014 & 104 & 28 & 26.9 \\
Farallon Island 2014 & 125 & 77 & 61.6 \\
Half Moon Bay 2014 & 108 & 72 & 66.7 \\
\hline Totals & 433 & 251 & 58.0 \\
\hline
\end{tabular}


Overall diet description. Across all locations and years, nearly 12,000 individual prey items were identified and categorized into 18 taxonomic groups representing 4 phyla and at least 13 distinct species (Table 2). At the lowest taxonomic level, Salps were the most important prey group to the diet across all areas and all years (32.78\% PSIRI), followed by Unidentified Crustaceans (16.91\% PSIRI), Unidentified Fishes (12.61\% PSIRI), and Euphausiids (11.14\% PSIRI). Salps occurred most frequently in sampled stomachs (39.44\% FO), followed by Unidentified Crustaceans (25.50\% FO), Unidentified Fishes (16.73\% FO), and Euphausiids (16.33\% FO), indicating which prey groups were eaten with some regularity.

Most of the prey groups observed in this study were present in stomach samples at all locations during both years (Table 3). Prey groups such as Salps, Euphausiids, Amphipods, Hyperiid Amphipods, Unidentified Crustaceans, and Market Squid were present in stomachs throughout both years at all study regions. However, there were rare species such as Citharichthys sordidus, Thetys vagina, and Pterotracheoida spp. that only occurred during one year at one location. 
Table 2

Diet composition at the lowest taxonomic level of Yellowtail Rockfish caught at Cordell Bank, the Farallon Islands, and Half Moon Bay in 2013 and 2014 ( $n=251$ stomachs).

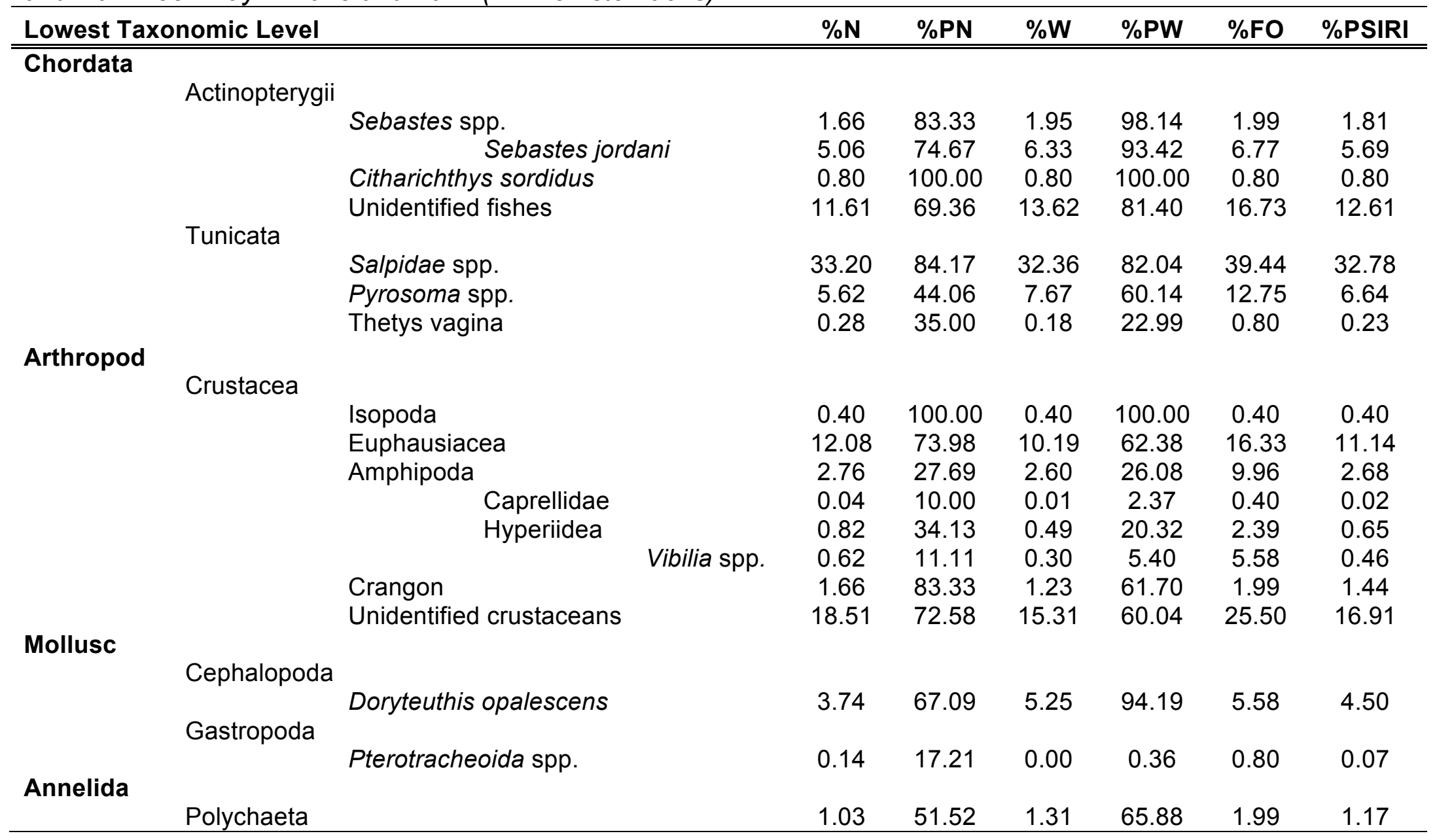


Table 3

Presence (shaded) and absence (unshaded) of prey groups at the lowest taxonomic level found in Yellowtail Rockfish (Sebastes flavidus) diets for each location and year. Abbreviations: $C=$ Cordell Bank, $F=$ Farallon Islands, $H=$ Half Moon Bay, $13=2013,14=2014$

\begin{tabular}{|c|c|c|c|c|c|c|c|c|}
\hline \multicolumn{4}{|c|}{ Lowest Taxonomic level } & C13 & F13 & C14 & F14 & H14 \\
\hline \multicolumn{9}{|l|}{ Chordata } \\
\hline & \multicolumn{8}{|l|}{ Actinopterygii } \\
\hline & & \multicolumn{2}{|l|}{ Sebastes spp. } & & & & & \\
\hline & & & Sebastes jordani & & & & & \\
\hline & & \multicolumn{2}{|l|}{ Citharichthys sordidus } & & & & & \\
\hline & & \multicolumn{2}{|l|}{ Unidentified fishes } & & & & & \\
\hline & \multicolumn{8}{|l|}{ Tunicata } \\
\hline & & \multicolumn{2}{|l|}{ Salpidae spp. } & & & & & \\
\hline & & \multicolumn{2}{|l|}{ Pyrosoma spp. } & & & & & \\
\hline & & \multicolumn{2}{|l|}{ Thetys vagina } & & & & & \\
\hline \multicolumn{9}{|l|}{ Arthropod } \\
\hline & \multicolumn{8}{|l|}{ Crustacea } \\
\hline & & \multicolumn{2}{|l|}{ Isopoda } & & & & & \\
\hline & & \multicolumn{2}{|l|}{ Euphausiacea } & & & & & \\
\hline & & \multicolumn{2}{|l|}{ Amphipoda } & & & & & \\
\hline & & & Caprellidae & & & & & \\
\hline & & & Hyperiidea & & & & & \\
\hline & & & Vibilia spp. & & & & & \\
\hline & & Crangon & & & & & & \\
\hline & & Unidentified crustaceans & & & & & & \\
\hline \multicolumn{9}{|l|}{ Mollusc } \\
\hline & \multicolumn{8}{|l|}{ Cephalopoda } \\
\hline & & \multicolumn{2}{|l|}{ Doryteuthis opalescens } & & & & & \\
\hline & \multicolumn{3}{|l|}{ Gastropoda } & & & & & \\
\hline & & Pterotracheoida spp. & & & & & & \\
\hline \multicolumn{9}{|l|}{ Annelida } \\
\hline & Polychaeta & & & & & & & \\
\hline
\end{tabular}


Sample size sufficiency. Based on generated cumulative prey curves for Yellowtail Rockfish, the number of stomachs collected for dietary analysis was sufficient at high (generalized) levels of prey categorization for each location and year. At the lowest level of taxonomic identification, samples sizes were not sufficient to adequately characterize the diets for each area and year. Therefore, for all other analyses, I utilized diet data grouped at the high levels of prey categorization (Table 4).

The cumulative prey curve for the Yellowtail Rockfish caught at Cordell Bank in 2013 did not reach an asymptote at the lowest taxonomic prey level $(b=$ $0.1241)$, but did reach an asymptote at the generalized prey level $(b=0.0331$, Figure 2). This indicated that enough samples $(n=33)$ were analyzed to adequately describe the diet at the generalized prey category level $(n=7)$. 
Table 4

Lowest taxonomic level identifications as determined by gut content analysis, and the associated higher (generalized) categories based on NMFS (2013).

\begin{tabular}{|c|c|c|}
\hline $\begin{array}{c}\text { Lowest Taxonomic } \\
\text { Level }\end{array}$ & $\begin{array}{c}\text { Higher (Generalized) } \\
\text { Category }\end{array}$ & $\begin{array}{c}\text { Generalized Category } \\
\text { Abbreviation }\end{array}$ \\
\hline $\begin{array}{l}\text { Sebastes spp. } \\
\text { Sebastes jordani }\end{array}$ & $\begin{array}{l}\text { Rockfish } \\
\text { Rockfish }\end{array}$ & ROCK \\
\hline $\begin{array}{c}\text { Citharichthys sordidus } \\
\text { Unknown fishes }\end{array}$ & $\begin{array}{l}\text { Teleosts } \\
\text { Teleosts }\end{array}$ & TELE \\
\hline $\begin{array}{c}\text { Salpidae spp. } \\
\text { Pyrosoma spp. } \\
\text { Thetys vagina }\end{array}$ & $\begin{array}{l}\text { Tunicates } \\
\text { Tunicates } \\
\text { Tunicates }\end{array}$ & TUN \\
\hline Euphausacea & Euphausiids & EUPH \\
\hline $\begin{array}{l}\text { Amphipoda } \\
\text { Caprellidae } \\
\text { Hyperiidea } \\
\text { Vibilia spp. }\end{array}$ & $\begin{array}{l}\text { Amphipods } \\
\text { Amphipods } \\
\text { Amphipods } \\
\text { Amphipods }\end{array}$ & AMPH \\
\hline $\begin{array}{c}\text { Cranqon } \\
\text { Unknown crustaceans }\end{array}$ & $\begin{array}{l}\text { Crustaceans } \\
\text { Crustaceans }\end{array}$ & CRUS \\
\hline Doryteuthis opalescens & Squid & SQUID \\
\hline $\begin{array}{c}\text { Isopoda } \\
\text { Pterotraecheoida spp. } \\
\text { Polychaeta }\end{array}$ & $\begin{array}{l}\text { Other } \\
\text { Other } \\
\text { Other }\end{array}$ & OTHER \\
\hline
\end{tabular}




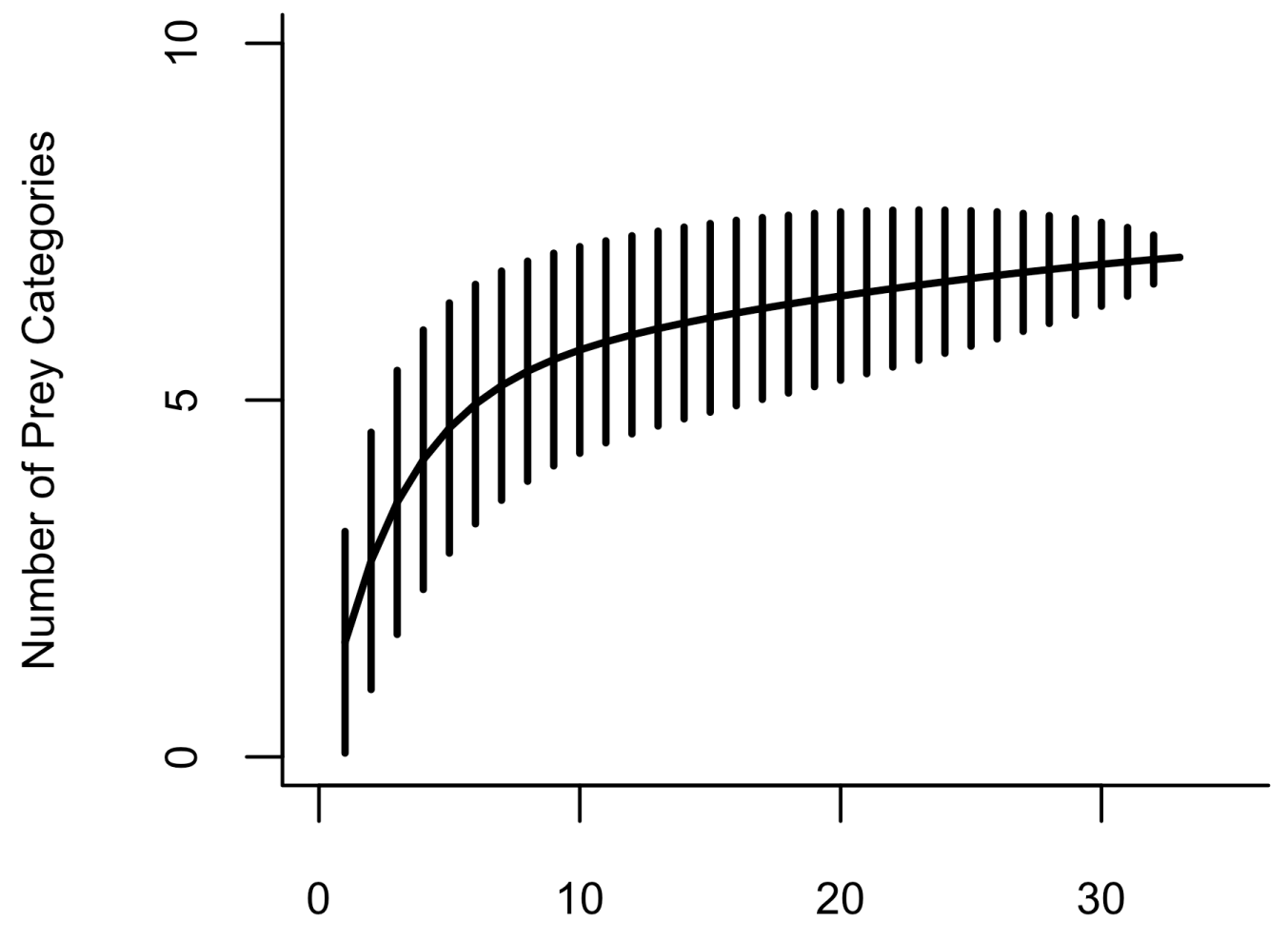

Number of Stomachs

Figure 2. Prey accumulation curve for Yellowtail Rockfish caught at Cordell Bank in 2013 at the generalized prey level. Vertical lines represent $95 \%$ confidence intervals around the mean. 
The cumulative prey curve for the Yellowtail Rockfish caught at the Farallon Islands in 2013 did not reach an asymptote at the lowest taxonomic prey level ( $b$ $=0.0976)$, but did reach an asymptote at the generalized prey level $(b=0.0488$, Figure 3). This indicated that enough samples $(n=41)$ were analyzed to adequately describe the diet at the generalized prey category level $(n=6)$.

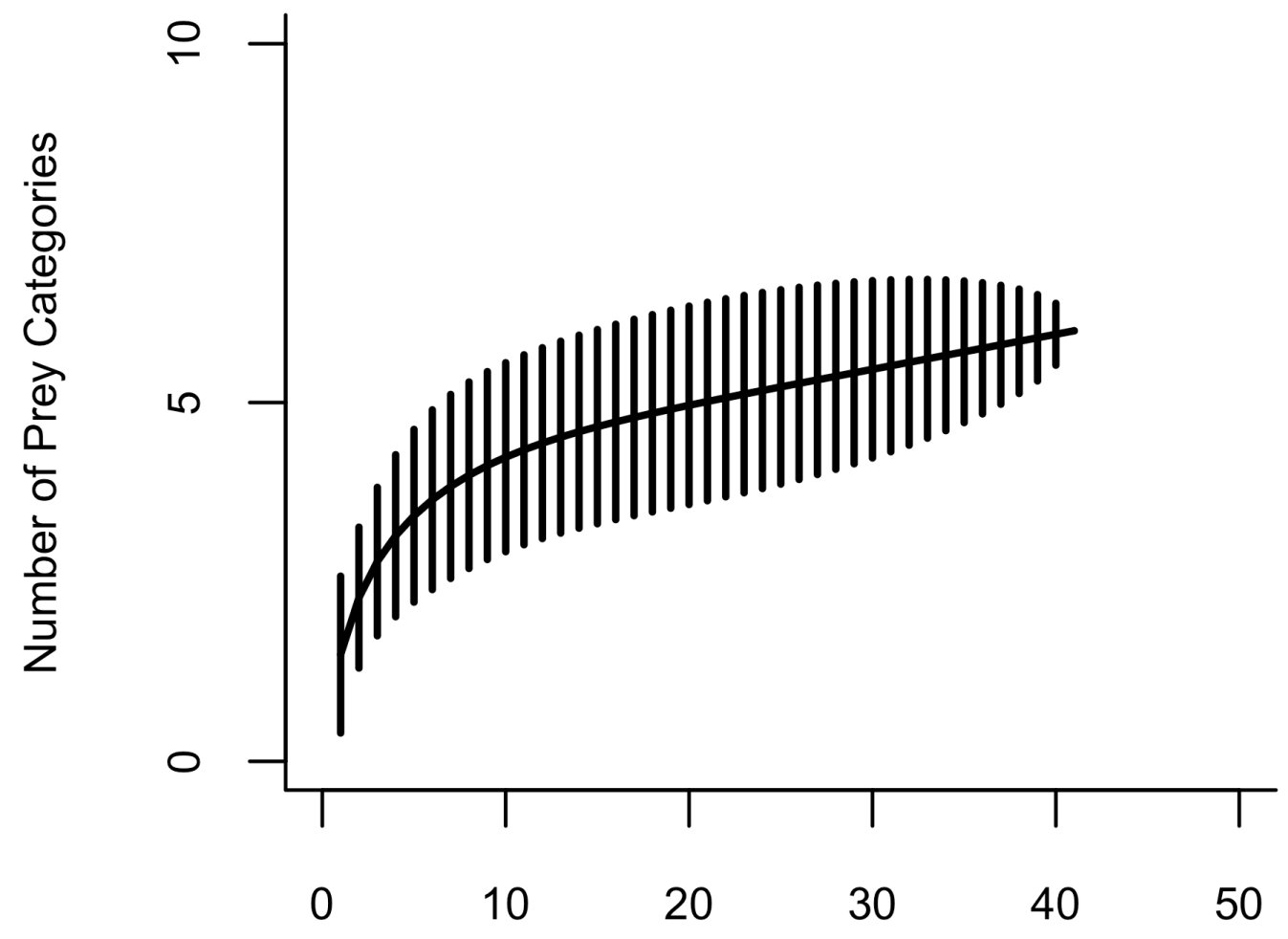

Number of Stomachs

Figure 3. Prey accumulation curve for Yellowtail Rockfish caught at the Farallon Islands 2013 at the generalized prey level. Vertical lines represent $95 \%$ confidence intervals around the mean. 
The cumulative prey curve for the Yellowtail Rockfish caught at Cordell Bank in 2014 did not reach an asymptote at the lowest taxonomic prey level $(b=$ $0.1508)$, but did reach an asymptote at the generalized prey level $(b=0.0397$, Figure 4). This indicated that enough samples $(n=28)$ were analyzed to adequately describe the diet at the generalized prey category level $(n=7)$.

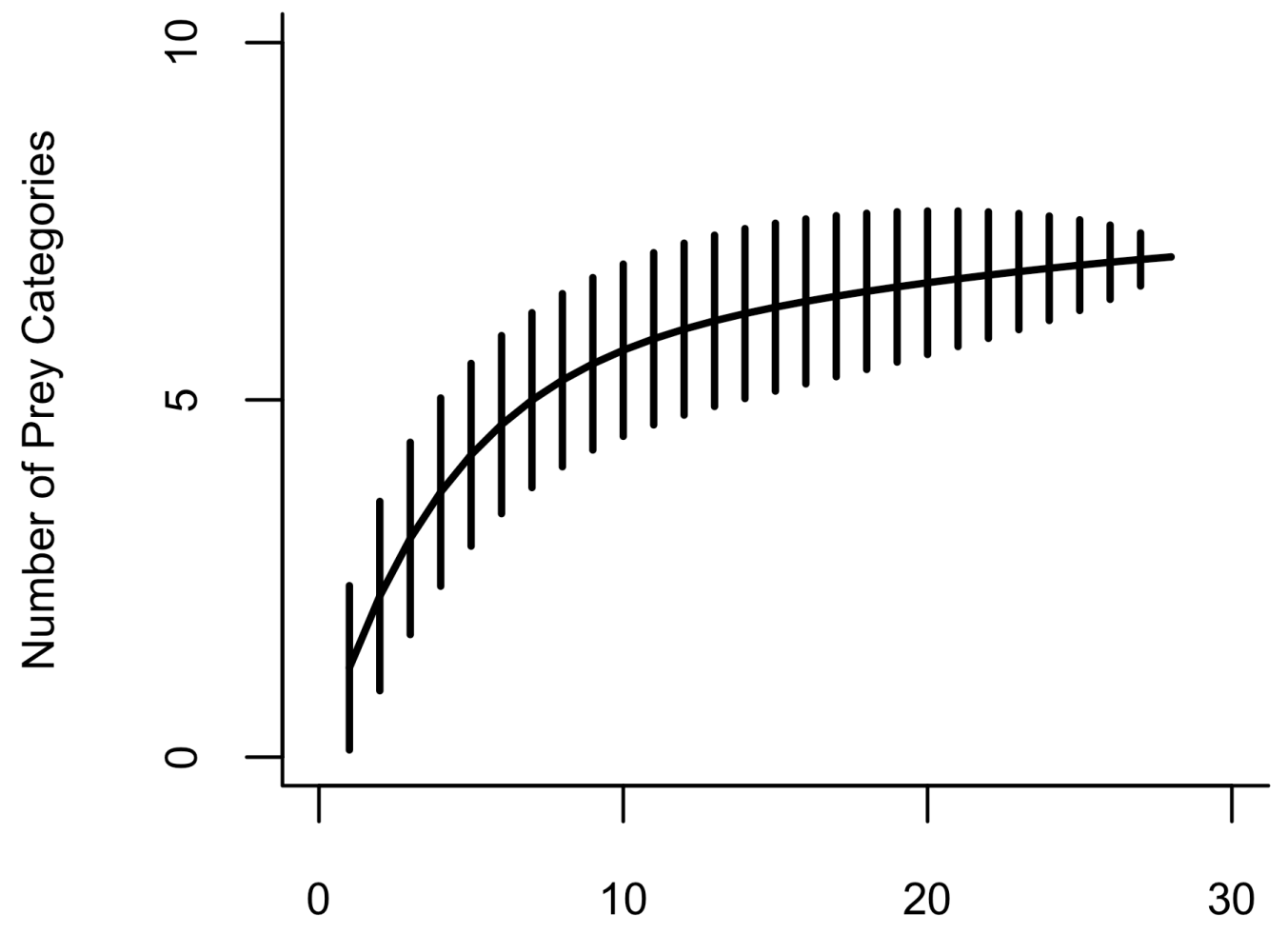

Number of Stomachs

Figure 4. Prey accumulation curve for Yellowtail Rockfish caught at Cordell Bank in 2014 at the generalized prey level. Vertical lines represent 95\% confidence intervals around the mean. 
The cumulative prey curve for the Yellowtail Rockfish caught at the Farallon Islands in 2014 reached an asymptote at the lowest taxonomic prey level $(b=$ $0.0135)$ and at the generalized prey level $(b=0.0130$, Figure 5). This indicated that enough samples $(n=77)$ were analyzed to adequately describe the diet at the generalized prey category level $(n=7)$.

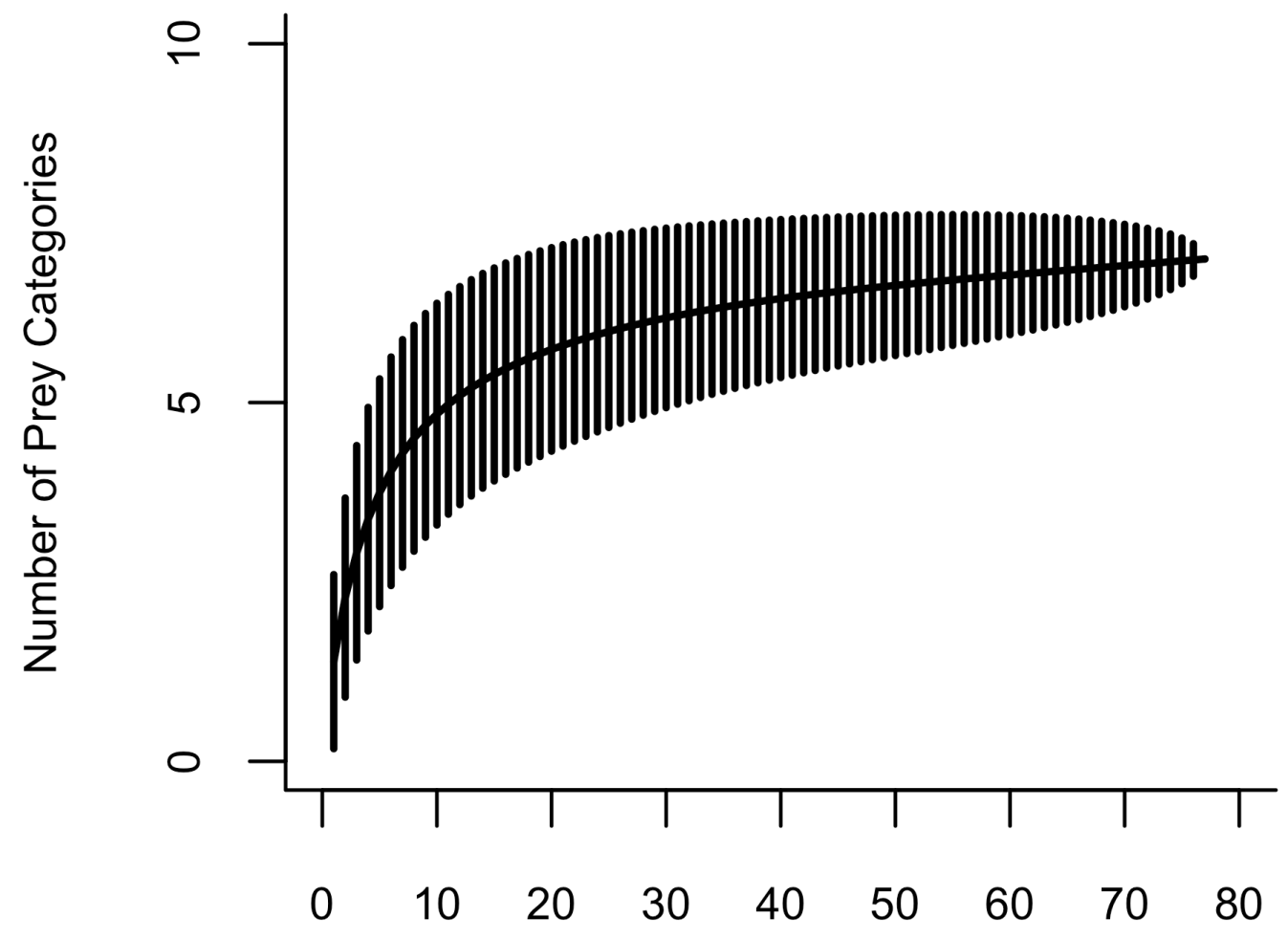

Number of Stomachs

Figure 5. Prey accumulation curve for Yellowtail Rockfish caught at the Farallon Islands in 2014 at the generalized prey level. Vertical lines represent $95 \%$ confidence intervals around the mean. 
The cumulative prey curve for the Yellowtail Rockfish caught at Half Moon Bay in 2014 did not reach an asymptote not at the lowest taxonomic prey level ( $b$ $=0.0567)$, but did reach an asymptote at the generalized prey level $(b=0.000)$, Figure 6). This indicated that enough samples $(n=72)$ were analyzed to adequately describe the diet at the generalized prey category level $(n=7)$.

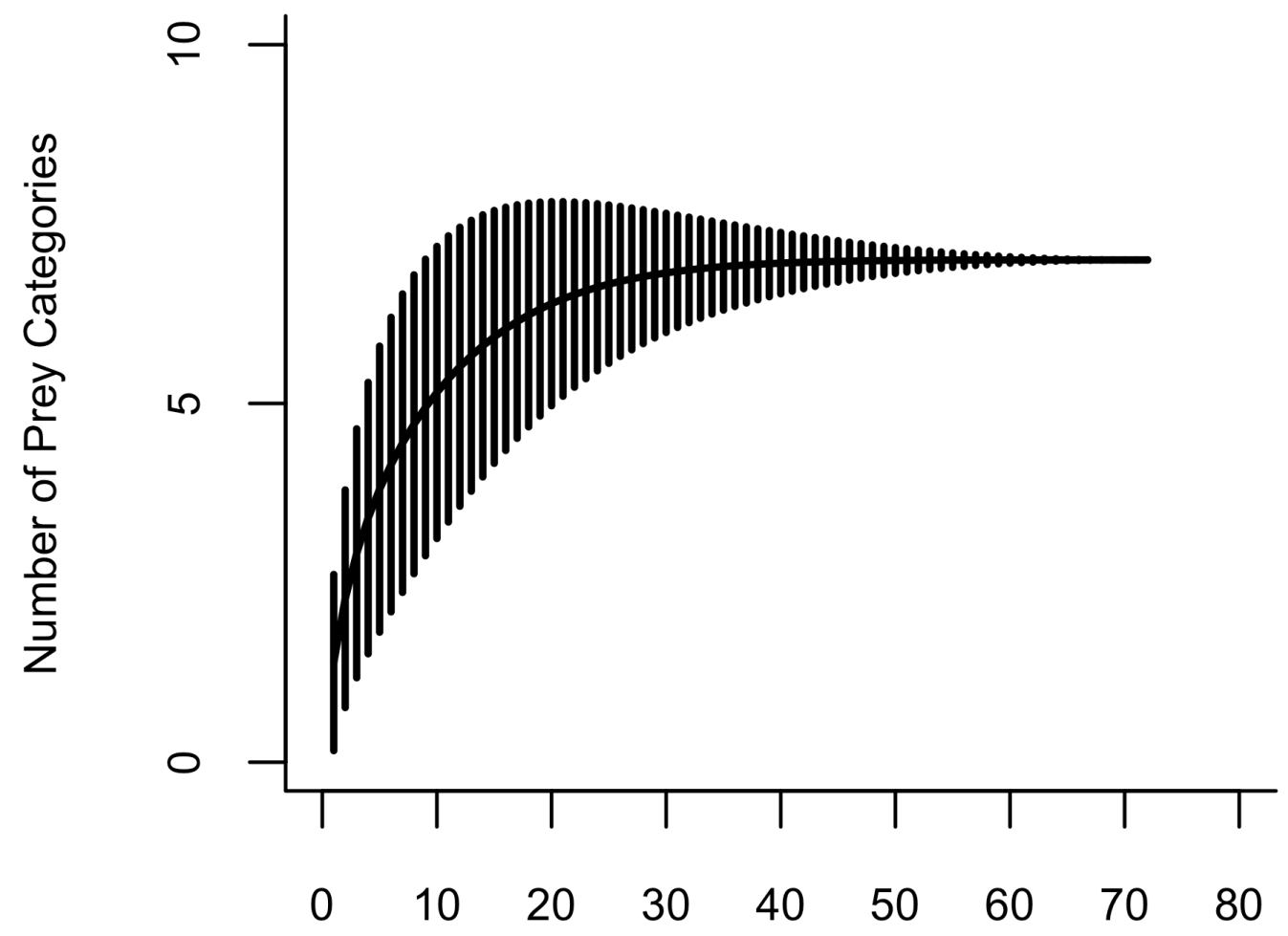

Number of Stomachs

Figure 6. Prey accumulation curve for Yellowtail Rockfish caught at Half Moon Bay in 2014 at the generalized prey level. Vertical lines represent $95 \%$ confidence intervals around the mean. 
Diet description using generalized taxonomic distinctions. Utilizing the generalized prey categories (Table 4) to evaluate diet composition from a broader perspective, the most important prey group to the diet of Yellowtail Rockfish at all locations over all years was Tunicates (39.65\% PSIRI), followed by Crustaceans (18.35\% PSIRI), and Teleosts (13.41\% PSIRI) (Table 5). Tunicates (45.82\% FO), Crustaceans (27.49\%) and Teleosts (17.53\% FO) were eaten with the most regularity. Tunicates had the highest prey-specific abundance by number ( $85.33 \%$ PN), while Rockfish had the highest prey-specific abundance by weight $(94.50 \% \mathrm{PW})$. This follows the common trend of finding higher numbers of smaller prey items, and fewer numbers of heavier prey items in stomachs. 
Table 5

Diet composition at the generalized prey level of Yellowtail Rockfish caught at Cordell Bank, the Farallon Islands, and Half Moon Bay in 2013 and 2014 ( $n=251$ stomachs). See Table 4 for the prey groups that comprise the generalized prey categories.

\begin{tabular}{lcccccc}
$\begin{array}{l}\text { Generalized Prey Category } \\
\text { (ABBREVIATION) }\end{array}$ & \%N & \%PN & \%W & \%PW & \%FO & \%PSIRI \\
\hline \hline Rockfish (ROCK) & 6.72 & 76.61 & 8.28 & 94.50 & 8.76 & 7.50 \\
Teleosts (TELE) & 12.40 & 70.75 & 14.42 & 82.24 & 17.53 & 13.41 \\
Tunicates (TUN) & 39.10 & 85.33 & 40.21 & 87.76 & 45.82 & 39.65 \\
Euphausiids (EUPH) & 12.08 & 73.98 & 10.19 & 62.38 & 16.33 & 11.14 \\
Amphipods (AMPH) & 4.23 & 24.71 & 3.39 & 19.81 & 17.13 & 3.81 \\
Crustaceans (CRUS) & 20.17 & 73.36 & 16.54 & 60.16 & 27.49 & 18.35 \\
Squid (SQUID) & 3.74 & 67.09 & 5.25 & 94.19 & 5.58 & 4.50 \\
Other (OTHER) & 1.56 & 49.00 & 1.71 & 53.77 & 3.19 & 1.64 \\
\hline
\end{tabular}


Cordell Bank in 2013. More than 1,500 individual prey items were identified and categorized into 10 taxonomic groups representing 4 phyla and at least 6 distinct species from 33 stomachs (Appendix 1). At the generalized prey level, Euphausiids (32.67\% PSIRI) were the most important prey group at Cordell Bank in 2013, followed by Tunicates (24.78\% PSIRI), Teleosts (18.9\% PSIRI), and then Rockfishes (14.84\% PSIRI) (Figure 7). For these 4 groups, the rank for frequency of occurrence was the same as PSIRI. \%PN and \%PW were variable across all prey groups at Cordell Bank in 2013 (Table 6). Rockfishes, Teleosts, and Market Squid exhibited higher \%PW than \%PN, whereas Tunicates, Amphipods, and Crustaceans had higher \%PN than \%PW. Euphausiids had about equal representation by \%PN and \%PW. 


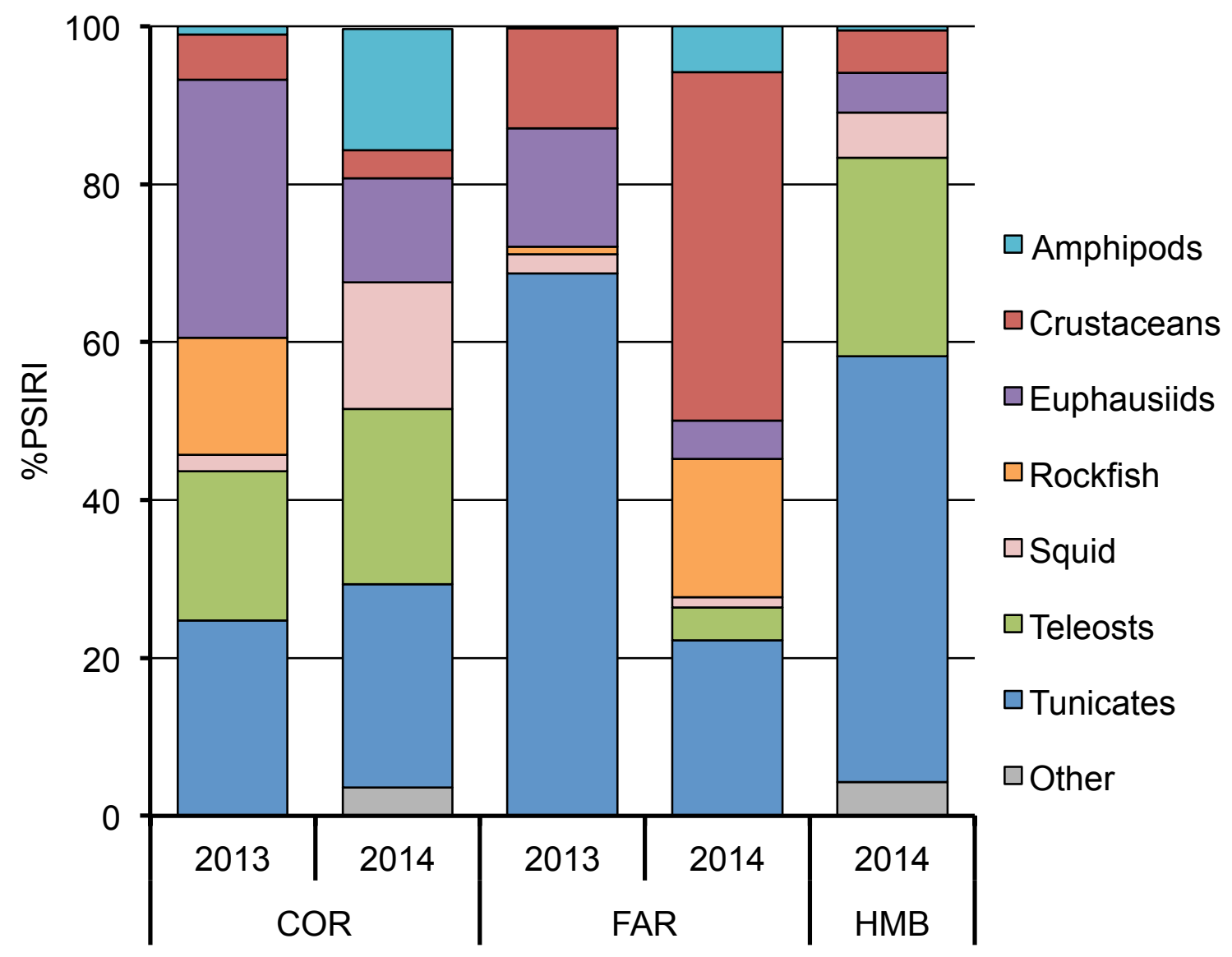

Figure 7. Distribution of generalized prey categories for each location and year based on calculated percent prey-specific index of relative importance (\%PSIRI), a metric used to determine the contribution of different prey groups to the overall diet. See Table 4 for prey categories. Abbreviations: COR $=$ Cordell Bank, FAR $=$ Farallon Islands, $\mathrm{HMB}=$ Half Moon Bay 
Table 6

Prey-specific abundance by number (\%PN) and prey-specific abundance by weight (\%PW) of 7 generalized prey categories in the diet of Yellowtail Rockfish at Cordell Bank, the Farallon Islands, and Half Moon Bay in 2013 and 2014. The prey category of "Other" was ommitted because it occurred so infrequently. Generalized prey categories (Table 2) are listed in alphabetical order. "---" at the Farallon Islands in 2013 indicates that no teleosts were found in the stomachs of Yellowtail Rockfish.

\begin{tabular}{lcc|cc|cc|cc|cc}
\hline & \multicolumn{2}{c}{ Cordell Bank } & \multicolumn{2}{c|}{ Farallon Islands } & \multicolumn{2}{c|}{ Cordell Bank } & \multicolumn{2}{c|}{ Farallon Islands } & \multicolumn{2}{c}{ Half Moon Bay } \\
& \%PN & \%PW & \%PN & \%PW & \%PN & \%PW & \%PN & \%PW & \%PN & \%PW \\
\hline Amph & 22.53 & 0.19 & 0.94 & 0.28 & 64.29 & 58.31 & 31.26 & 28.34 & 15.06 & 3.32 \\
Crus & 30.93 & 16.69 & 88.89 & 84.02 & 60.00 & 50.22 & 82.30 & 68.77 & 57.14 & 39.80 \\
Euph & 77.26 & 66.48 & 78.40 & 75.10 & 85.80 & 61.84 & 80.00 & 68.05 & 52.26 & 38.76 \\
Rock & 52.69 & 87.20 & 0.52 & 77.81 & 100.00 & 100.00 & 94.05 & 99.34 & 41.72 & 47.16 \\
Squid & 33.33 & 99.22 & 100.00 & 100.00 & 80.87 & 99.01 & 100.00 & 100.00 & 50.25 & 87.39 \\
Tele & 51.51 & 87.10 & --- & -- & 80.95 & 95.97 & 77.50 & 81.06 & 73.86 & 76.62 \\
Tun & 87.31 & 61.38 & 94.10 & 93.75 & 73.00 & 71.53 & 56.03 & 81.00 & 68.39 & 67.81 \\
\hline
\end{tabular}


Farallon Islands in 2013. Nearly 8,600 individual prey items were identified and categorized into 9 taxonomic groups representing 4 phyla and at least 6 distinct species from 41 stomachs (Appendix 1). Tunicates (68.44\% PSIRI) were the most important prey group at the Farallon Islands in 2013 , followed by Euphausiids (14.98\% PSIRI) and Crustaceans (112.65\% PSIRI) (Figure 7). Tunicates occurred most frequently in stomachs, followed by Amphipods and Euphausiids. \%PN and \%PW were nearly equal for most groups, with the exception of Rockfishes, where \%PW was significantly higher than \%PN (Table 6)

Cordell Bank in 2014. Almost 90 individual prey items were identified and categorized into 12 taxonomic groups representing 5 phyla and at least 9 distinct species from 28 stomachs (Appendix 1). Tunicates (25.81\% PSIRI) were the most important prey group, followed by Teleosts (22.11\% PSIRI), Market Squid (16.06\% PSIRI), and Amphipods (15.33\% PSIRI) (Figure 7). Tunicates and Amphipods were the prey groups that occurred most frequently. $\% \mathrm{PN}$ and $\% \mathrm{PW}$ were nearly equal for most prey groups (Table 6). \%PN of Amphipods, Crustaceans, Euphausiids and Tunicates was higher than \%PW, while the reverse was true for Market Squid and Teleosts.

Farallon Islands in 2014. About 560 individual prey items were identified and categorized into 12 taxonomic groups representing 4 phyla and at least 7 distinct species form 77 stomachs (Appendix 1). Crustaceans (42.47\% PSIRI) were the most important prey group, followed by Tunicates (22.64\% PSIRI) and 
Rockfishes (17.58\% PSIRI) (Figure 7). The most frequently occurring species were Crustaceans, Tunicates, Amphipods, and Rockfishes, respectively. \%PN was higher than \%PW for Amphipods, Euphausiids, and Crustaceans, while the opposite was true for Rockfish, Teleosts, and Tunicates (Table 6).

Half Moon Bay in 2014. Over 1,100 individual prey items were identified and categorized into 14 taxonomic groups representing 6 phyla and at least 11 distinct species in 72 stomachs (Appendix 1). Tunicates (53.91\% PSIRI) were the most important prey group, followed by Teleosts (25.08\% PSIRI) (Figure 7). Tunicates, followed by Teleosts and Euphausiids were the most frequently occurring groups. \%PN was higher than \%PW for Euphausiids, Amphipods, and Crustaceans (Table 6). \%PW was higher than \%PN for Rockfish, Market Squid, and Teleosts.

Trophic level. The trophic level of Yellowtail Rockfish diets among all years and locations ranged from 3.25 to 4.24 , with an overall mean of 3.69 (Figure 8). The minimum (3.25) and maximum (4.24) values of this range corresponded to Euphausiid-exclusive or fish-exclusive diets, respectively. Trophic level calculations that fall within this range indicate that fish ate a combination of prey categories representing different trophic levels. Although this trophic level range was consistent when locations were evaluated individually, the distribution of trophic level calculations within this range yielded slightly different means for each location (Cordell Bank: 3.81, Farallon Islands: 3.60, Half Moon Bay: 3.74). 
The modal trophic level calculation among all years and locations was 3.5, indicating most Yellowtail Rockfish sampled had a primarily invertebrate diet.

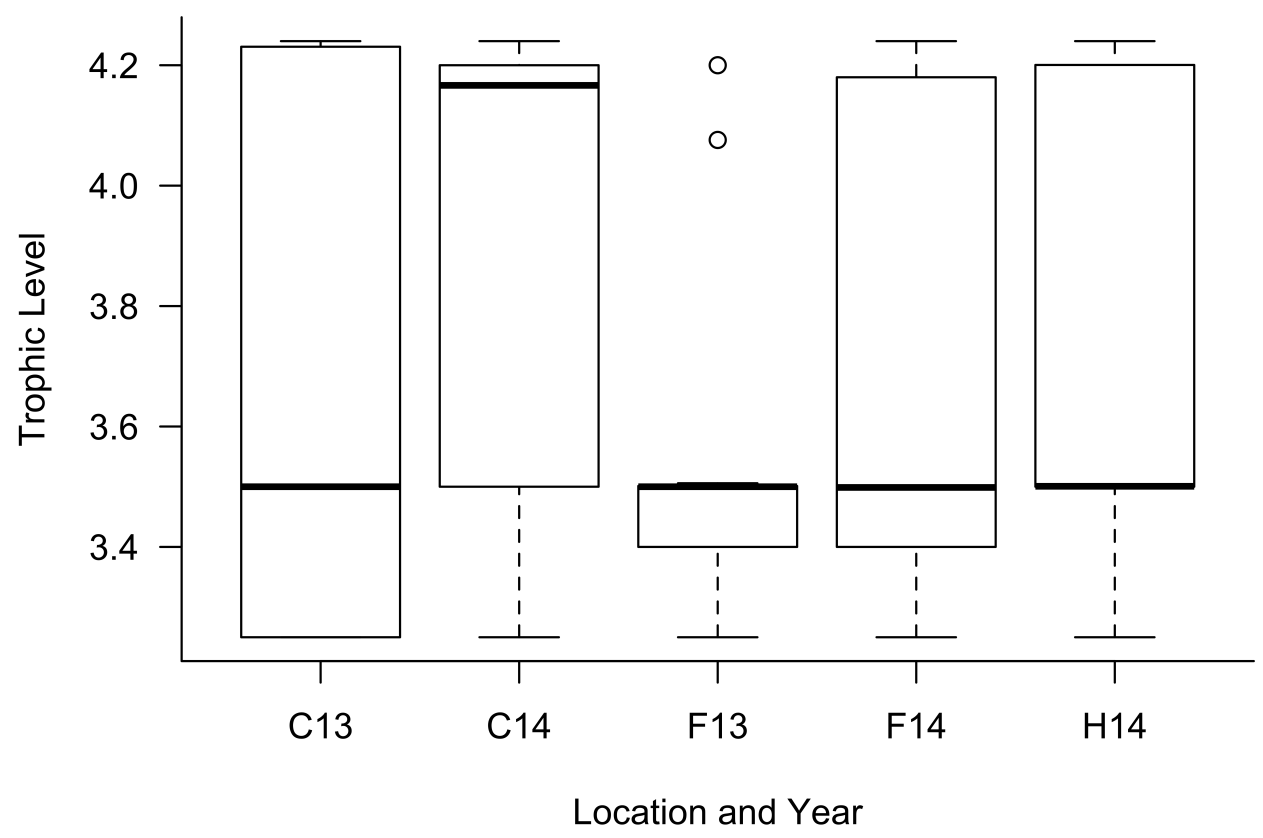

Figure 8. Box plot of the trophic level distributions for all locations and years. Bolded line inside each box represents the sample mean. Horizontal lines at the top and bottom of each box represent $+/-1.5^{*}$ IQR. Open circles denote points that fall outside this range. Abbreviations: $\mathrm{C}=$ Cordell Bank, $\mathrm{F}=$ Farallon Islands, $\mathrm{H}=$ Half Moon Bay, $13=2013,14=2014$

At a 0.05 significance level, I concluded that trophic level was not identical across all locations and years (chi-squared $=18.459, d f=4, p=0.001$ ). Results of the Games-Howell post-hoc test indicated that there were significant differences in trophic level among 4 location/year combinations (Table 7). Yellowtail Rockfish caught at Cordell Bank in 2013 were consuming more Euphausiids compared to those caught at Cordell Bank in 2014. At the Farallon Islands, Yellowtail Rockfish caught in 2013 were eating much higher proportions of Tunicates, while Crustaceans and Rockfishes were important contributors to 
the diets in 2014. The significant difference observed between Cordell Bank 2014 and the Farallon Islands 2013 is due to the Teleosts and Market Squid observed at Cordell Bank in 2014 and the large proportion of Tunicates in stomachs at the Farallon Islands in 2013. Although the importance of Tunicates was similar, Half Moon Bay 2014 had a much larger proportion of Teleosts compared to the Farallon Islands in 2013 , which contributed to the significant difference in trophic level calculation.

\section{Table 7}

Summary of Games-Howell Significant Difference test results for trophic level with $p$-values to indicate signifiant differences among location/year combinations Location/Year Combinations P-Value

Cordell Bank 2013 / Farallon Islands 2013

Cordell Bank 2013 / Cordell Bank 2014

Cordell Bank 2013 / Farallon Islands 2014

Cordell Bank 2013 / Half Moon Bay 2014

Farallon Islands 2013 / Cordell Bank 2014

Farallon Islands 2013 / Farallon Islands 2014

Farallon Islands 2013 / Half Moon Bay 2014

Cordell Bank 2014 / Farallon Islands 2014

Cordell Bank 2014 / Half Moon Bay 2014

Farallon Islands 2014 / Half Moon Bay 2014

\subsection{4}

0.768

0.817

1.000

$<0.001$

0.003

$<0.001$

0.090

0.484

0.655 
Effects of total length. In general, fish caught at Cordell Bank were larger (mean $=40.6 \mathrm{~cm}$ TL in $2013,40.7 \mathrm{~cm}$ in 2014) than those caught at the Farallon Islands (mean $=31.4 \mathrm{~cm}$ TL in 2013, $30.5 \mathrm{~cm}$ in 2014) and Half Moon Bay (mean $=30.4 \mathrm{~cm}$ in 2014) (Figure 9). An ANOVA indicated that there were significant differences in the lengths for each location and year $\left(F_{4,250}=84.11, p=\right.$ <0.0001). Cordell 2013 and Cordell 2014 were significantly different from all other groups (Tukey's Honest Significant Difference test, $p<0.001$ ).

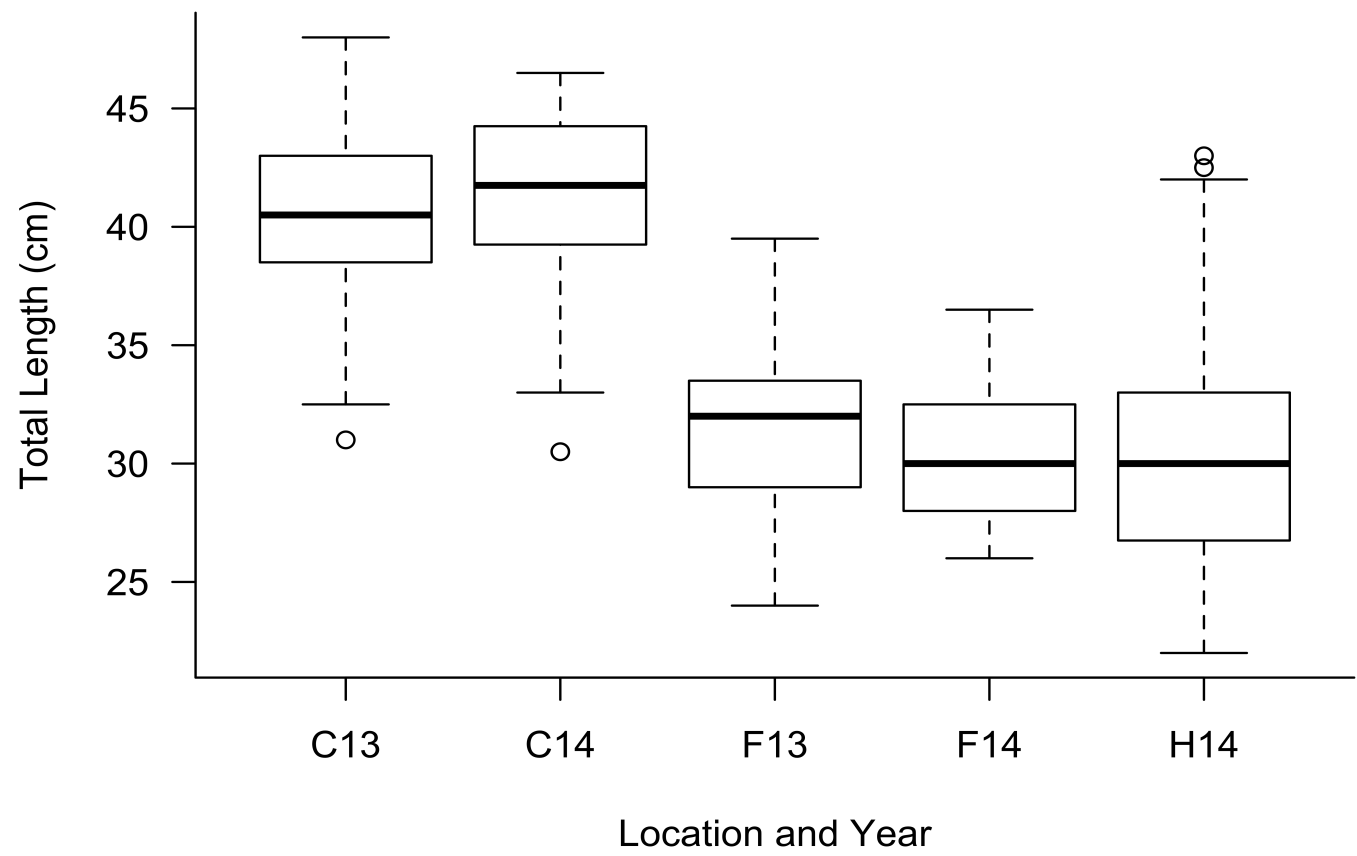

Figure 9. Box plot of total length $(\mathrm{cm})$ by location and year. Bolded line inside each box represents the sample mean. Horizontal lines at the top and bottom of each box are represented by $+/-1.5$ * IQR. Open circles denote points that fall outside this range. Abbreviations: $\mathrm{C}=$ Cordell Bank, $\mathrm{F}=$ Farallon Islands, $\mathrm{H}=$ Half Moon Bay, $13=2013,14=2014$ 
There was no significant relationship between total length and trophic level by sex (ANCOVA, $F_{1,191}=0.172, p=0.679$ ) indicating that neither sex was eating at a different trophic level with increasing length (Figure 10).

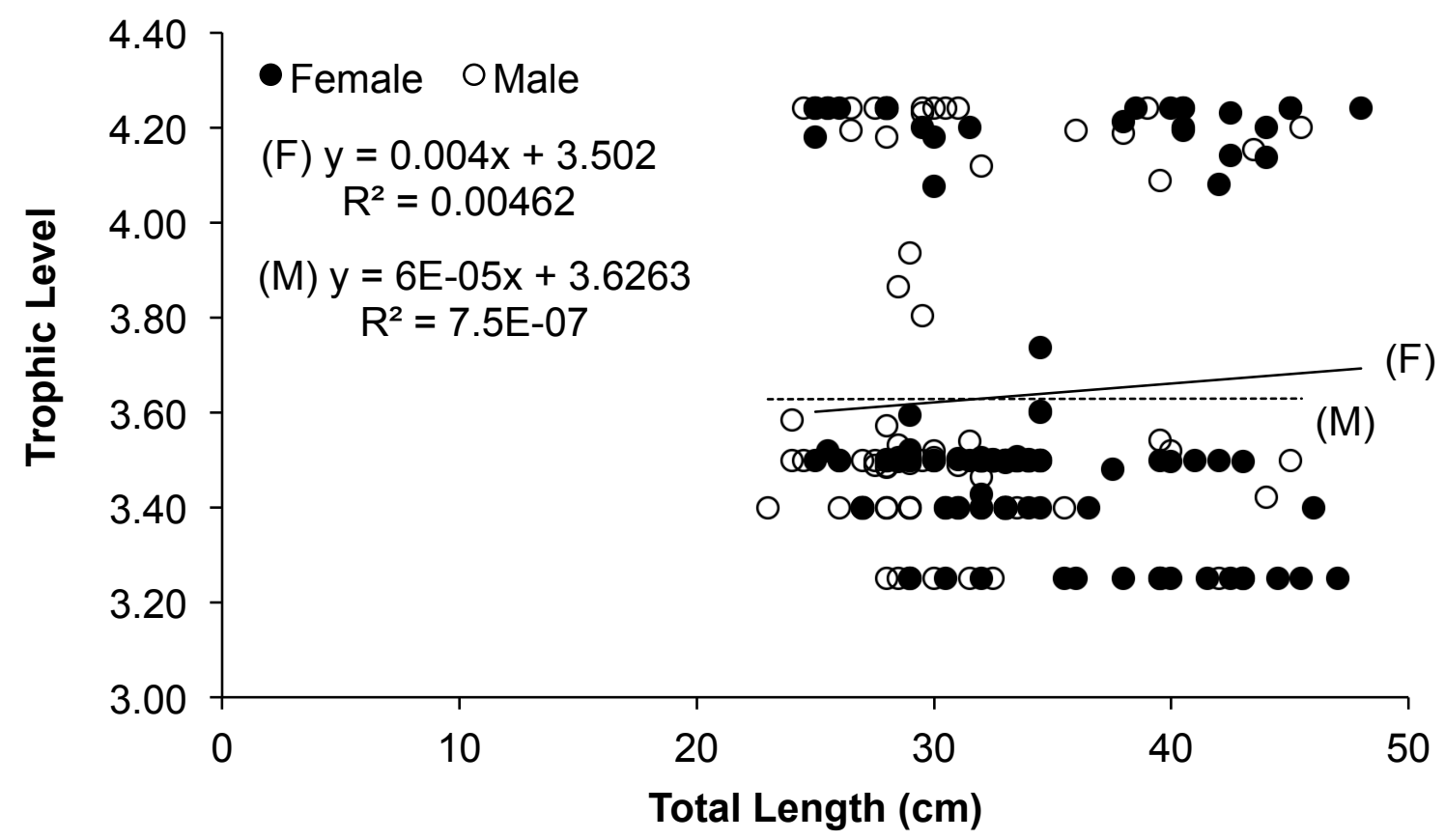

Figure 10. Trophic levels of female and male Yellowtail Rockfish diets as a function of total length

Stomach content weight plotted as a function of total length showed no significant relationship between sexes (ANCOVA, $F_{1,191}=0.822, p=0.3656$ ). However, there was a significant positive relationship between stomach content weight and total length for both sexes combined $\left(F_{1,191}=15.096, p=0.0001\right.$, Figure 11), indicating that larger fishes were eating heavier prey items. 


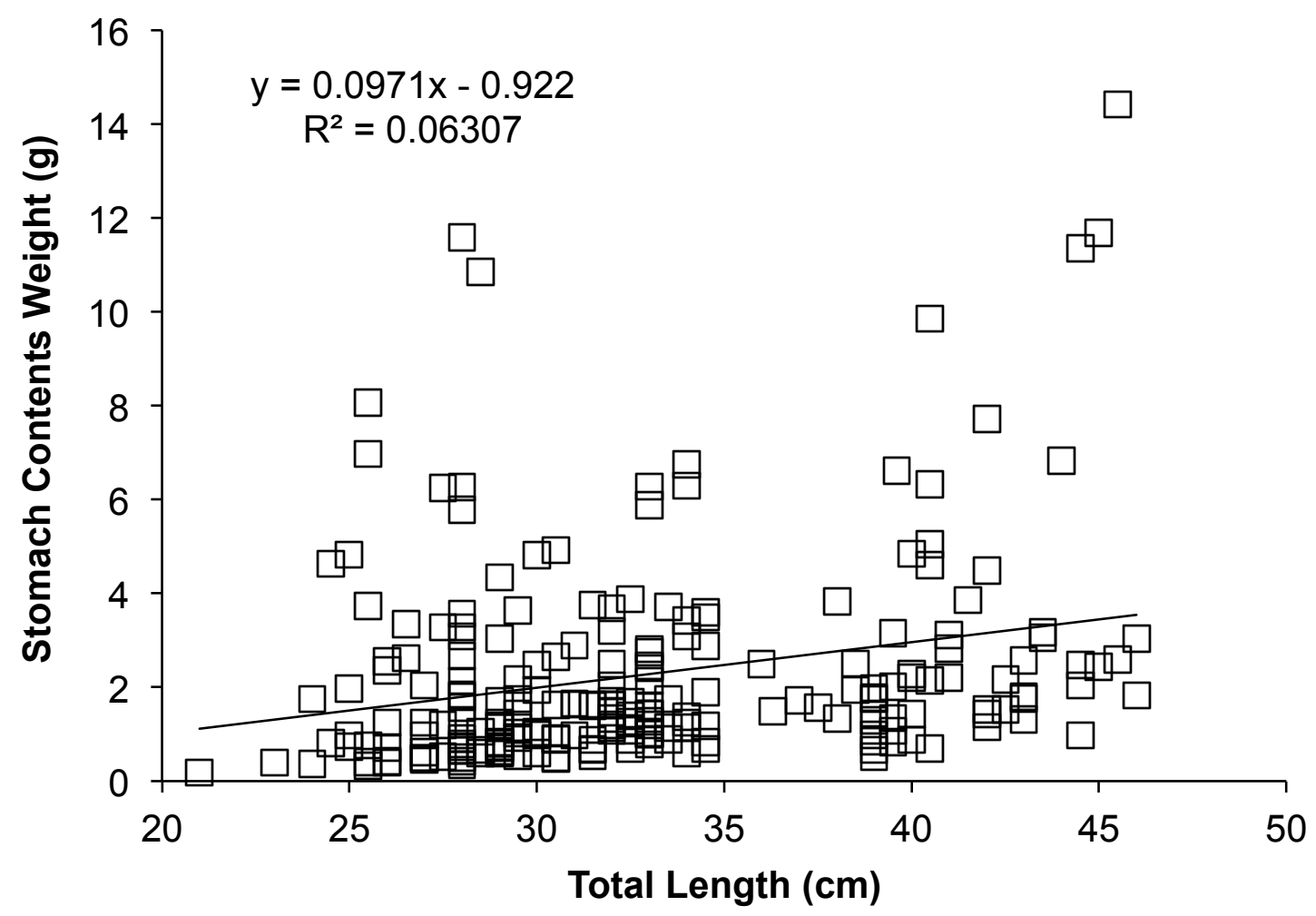

Figure 11. Yellowtail Rockfish stomach content weight as a function of total length for both sexes combined

Determining effects of temporal and spatial factors on diet. Location was the greatest source of diet variability for Yellowtail Rockfish in central California by each measure, followed by Year (Table 8). In combination, these variables explained $12.5 \%$ of dietary variation by $\% \mathrm{~N}$ and $10.4 \%$ by $\% \mathrm{~W}$ in the final PERMANOVA models. Depth was also a significant explanatory variable and accounted for an additional $1.7 \%(\% \mathrm{~N})$ and $2.4 \%(\% \mathrm{~W})$ of overall dietary variation. Furthermore, the multivariate interaction between Location and Year was significant, and explained $3.0 \%(\% \mathrm{~N})$ and $2.4 \%(\% \mathrm{~W})$ of overall dietary variation (Table 8). Permutation tests for homogeneity of multivariate dispersions 
showed that Location, Year, and Depth were significant for $\% \mathrm{~N}$, and Location and Depth were significant for \%W (Table 8 ). Considerable dietary variability was evident among and within explanatory variables.

\section{Table 8}

PERMANOVA models of prey composition among several response variables for Yellowtail Rockfish at Cordell Bank, the Farallon Islands, and Half Moon Bay in 2013 and 2014 ( $n=251$ stomachs)

\begin{tabular}{|c|c|c|c|c|c|c|c|c|}
\hline \multirow[t]{2}{*}{ Model(s) } & \multirow[t]{2}{*}{ Variables(s) } & \multirow[t]{2}{*}{$d f$} & \multicolumn{3}{|c|}{$\% N$} & \multicolumn{3}{|c|}{$\% \mathrm{~W}$} \\
\hline & & & $F$ & $r^{2}$ & $P$ & $F$ & $r^{2}$ & $P$ \\
\hline \multirow{5}{*}{ Final Model } & Location & $\overline{22}$ & 111.917 & 0.08084 & 0.0001 & 10.843 & 0.07536 & 0.0001 \\
\hline & Year & 1 & 12.982 & 0.04403 & 0.0001 & 8.2323 & 0.02861 & 0.0001 \\
\hline & Depth & 1 & 5.1549 & 0.01748 & 0.0001 & 6.8775 & 0.02390 & 0.0003 \\
\hline & $\begin{array}{l}\text { Location } \mathrm{x} \\
\text { Year }\end{array}$ & 1 & 2.7351 & 0.03012 & 0.0001 & 6.9887 & 0.02428 & 0.0001 \\
\hline & Residuals & 244 & & 0.82753 & & & 0.84786 & \\
\hline \multirow{5}{*}{$\begin{array}{l}\text { Independent } \\
\text { Variables }\end{array}$} & Location & 2 & 10.861 & 0.08084 & 0.0001 & 10.065 & 0.07536 & 0.0001 \\
\hline & Year & 1 & 6.5536 & 0.02575 & 0.0001 & 4.2935 & 0.01702 & 0.0019 \\
\hline & Depth & 1 & 5.8124 & 0.0229 & 0.0005 & 5.2291 & 0.02065 & 0.0006 \\
\hline & Sex & 2 & 3.2842 & 0.0259 & 0.0019 & 1.6698 & 0.01334 & 0.0918 \\
\hline & Length & 1 & 3.4667 & 0.01379 & 0.0072 & 4.2768 & 0.01695 & 0.0035 \\
\hline $\begin{array}{l}\text { Interaction } \\
\text { Effects }\end{array}$ & $\begin{array}{l}\text { Location x } \\
\text { Year }\end{array}$ & 4 & 11.078 & 0.15316 & 0.0001 & 9.0535 & 0.12878 & 0.0001 \\
\hline
\end{tabular}

Note: Degrees of freedom ( $d f)$, F-statistic, amount of variability explained $\left(r^{2}\right)$, and $P$ value are included for percent number $(\% \mathrm{~N})$ and percent weight $(\% \mathrm{~W})$ data. $P$ values that are italicized and in red text indicate significant results from multivariate homogeneity of group dispersion tests to the $P<0.01$ level. 
Additional PERMANOVA models that included the variable of Date were created to determine if diets were significantly changing over finer temporal scales than a year. In the final model for both $\% \mathrm{~N}$ and $\% \mathrm{~W}$, Date was the greatest source of dietary variability, explaining $36.1 \%$ and $38.6 \%$ of the variability, respectively (Table 9). This is considerably more variability explained than the previous PERMANOVA models that did not include Date. Four of the five independent variables were significant when tested in individual models for $\% \mathrm{~N}$ and $\% \mathrm{~W}$ (Date, Location, Length, and Depth). The interaction term tested was also significant for both models. No additional significance was added when Location, Length, or Depth was included, and the $r^{2}$ did not increase. Therefore, the final model only contained Date. Permutation tests for homogeneity of multivariate dispersions showed that Date, Location and Depth were significant for $\% \mathrm{~N}$, and Date and Location were significant for \%W (Table 9). 
Table 9

PERMANOVA models of prey composition among several response variables, including Date, for Yellowtail Rockfish at Cordell Bank and the Farallon Islands in 2013 ( $n=74$ stomachs)

\begin{tabular}{lll|ccc|ccc}
\hline Model(s) & Variables(s) & $d f$ & \multicolumn{3}{|c|}{$\% \mathrm{~N}$} & \multicolumn{3}{c}{$\% \mathrm{~W}$} \\
\cline { 4 - 8 } & & & $F$ & $r^{2}$ & $P$ & $F$ & $r^{2}$ & $P$ \\
\hline \hline \multirow{2}{*}{ Final Model } & Date & 5 & 7.692 & 0.36126 & 0.0001 & 8.5384 & 0.38568 & 0.0001 \\
& Residuals & 68 & & 0.63874 & & & 0.61432 \\
\hline $\begin{array}{l}\text { Independent } \\
\text { Variables }\end{array}$ & Date & 5 & 7.692 & 0.36126 & 0.0001 & 8.5384 & 0.38568 & 0.0001 \\
& Location & 1 & 7.4127 & 0.09334 & 0.0008 & 10.543 & 0.12772 & 0.0001 \\
& Length & 1 & 9.0655 & 0.11183 & 0.0003 & 10.363 & 0.12582 & 0.0001 \\
& Depth & 1 & 5.2652 & 0.06814 & 0.0026 & 4.9173 & 0.06393 & 0.0015 \\
& Sex & 1 & 0.1882 & 0.00261 & 0.9425 & 0.4070 & 0.00562 & 0.8023 \\
\hline Interaction & Date $x$ & 5 & 7.692 & 0.36126 & 0.0001 & 8.5384 & 0.38568 & 0.0001 \\
Effects & Location & 5 & & & & & & \\
\hline
\end{tabular}

Note: Degrees of freedom $(d f)$, F-statistic, amount of variability explained $\left(r^{2}\right)$, and $P$ value are included for percent number $(\% \mathrm{~N})$ and percent weight $(\% \mathrm{~W})$ data. $P$ values that are italicized and in red text indicate significant results from multivariate homogeneity of group dispersion tests to the $P<0.01$ level.

CCA results were similar with those of PERMANOVA analysis for Yellowtail Rockfish in Central California, and indicated dietary separation associated with Location and Year for both $\% \mathrm{~N}$ and \%W. Both models were highly significant $(\% \mathrm{~N}: F=7.7565, P<0.001 ; \% \mathrm{~W}: F=4.3338, P<0.001)$, but only explained a small amount of the overall dietary variability $(12.1 \%$ by $\% \mathrm{~N}$ and $11.1 \%$ for $\% \mathrm{~W})$. CCA1 $(42.15 \%$ by $\% \mathrm{~N}$ and $41.35 \%$ by $\% \mathrm{~W})$ and CCA2 $(28.93 \%$ by $\% \mathrm{~N}$ and $25.64 \%$ for $\% \mathrm{~W}$ ) explained most of the total variability seen in the final CCA models. Four of the five explanatory variables in the overall model were significant to the $P<0.05$ level for \%N (Location, Year, Depth, and Sex), and 
three of the five explanatory variables were significant for \%W (Location, Year, and Depth) (Table 10).

Table 10

Summary of results of the overall CCA model by factor for $\% \mathrm{~N}$ and $\% W$.

Significant factors are in bold text

\begin{tabular}{lcc|cc}
\hline & \multicolumn{2}{c|}{ \%N } & \multicolumn{2}{c}{ \%W } \\
Factor & F-Value & P-Value & F-Value & P-Value \\
\hline \hline Overall Model & 4.7565 & $\mathbf{0 . 0 0 1}$ & 4.3338 & $\mathbf{0 . 0 0 1}$ \\
Location & 8.0721 & $\mathbf{0 . 0 0 1}$ & 7.7194 & $\mathbf{0 . 0 0 1}$ \\
Year & 7.5534 & $\mathbf{0 . 0 0 1}$ & 5.8055 & $\mathbf{0 . 0 0 1}$ \\
Depth & 4.7303 & $\mathbf{0 . 0 0 1}$ & 5.6412 & $\mathbf{0 . 0 0 1}$ \\
Sex & 1.7882 & $\mathbf{0 . 0 3 1}$ & 1.2537 & 0.228 \\
Length & 1.2915 & 0.273 & 0.9434 & 0.458 \\
\hline
\end{tabular}

Biplots of CCA1 and CCA2 displayed similar results for both \%N (Figure 12) and $\% \mathrm{~W}$ (Figure 13) metrics. Overall dietary variability was primarily explained by the factors of Location, followed by Year. CCA1 displayed a clear spatial effect, with the locations of Half Moon Bay and Cordell Bank separating out from the Farallon Islands. Increased Depth was associated with Cordell Bank and Half Moon Bay, as well as increased numbers and weights of Teleosts and Other. Higher numbers of Market Squid and Tunicates were also associated with Half Moon Bay and Cordell Bank. On the contrary, the Farallon Islands were highly associated with increased numbers and weights of Crustaceans. Higher numbers of Rockfish and Amphipods also associated with the Farallon Islands. CCA2 displayed temporal differences, with the Years 2013 and 2014 separating 
along this axis. Numbers and weights of Euphausiids were highly associated with fishes caught in 2013.

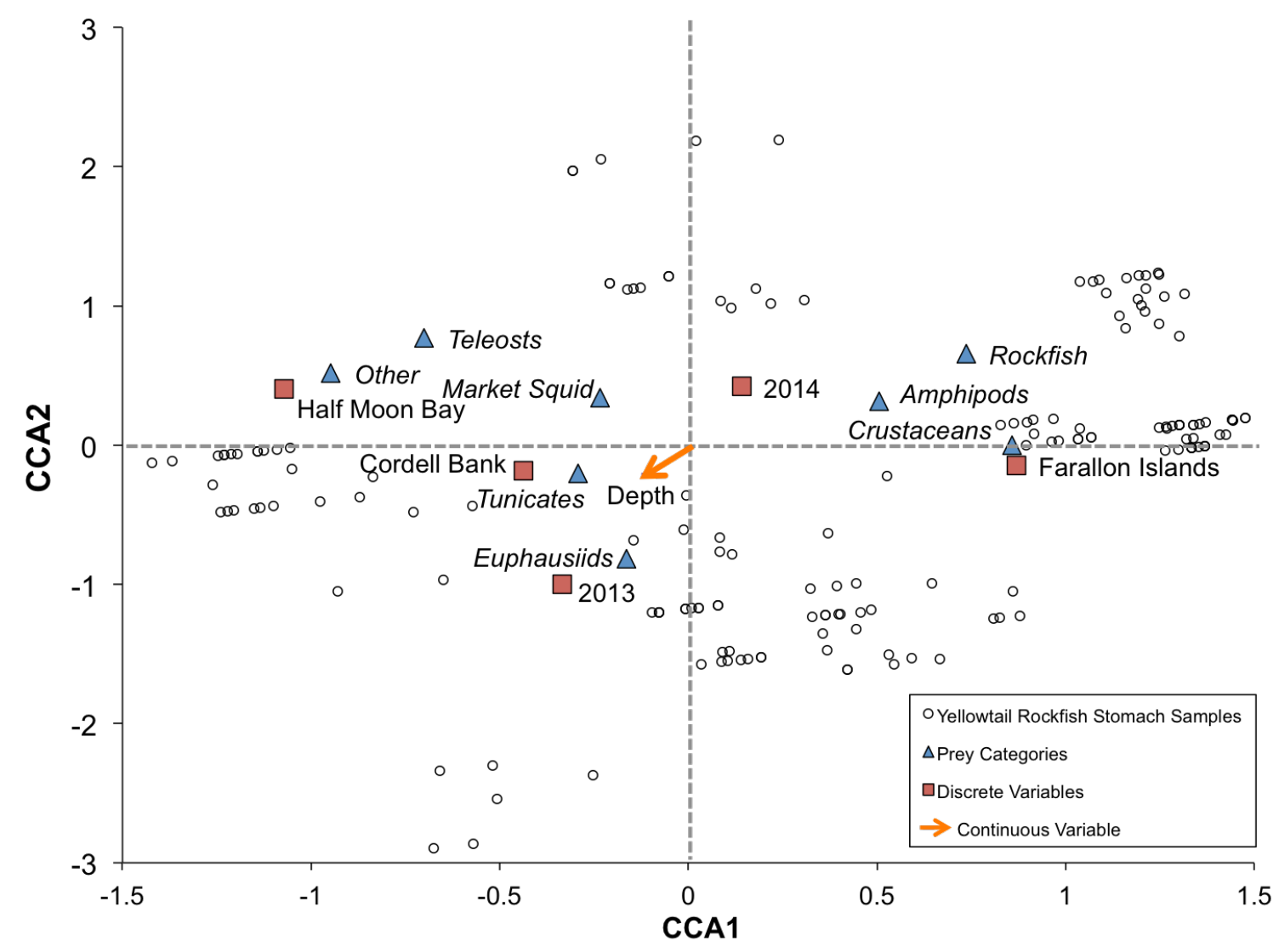

Figure 12. CCA biplot of the relationships between Yellowtail Rockfish stomach samples (black open circles), prey categories (blue triangles), and significant response variables (discrete as squares (red for Location, green for Date), and continuous as orange arrows) based on $\% \mathrm{~N}$ in all locations and years 


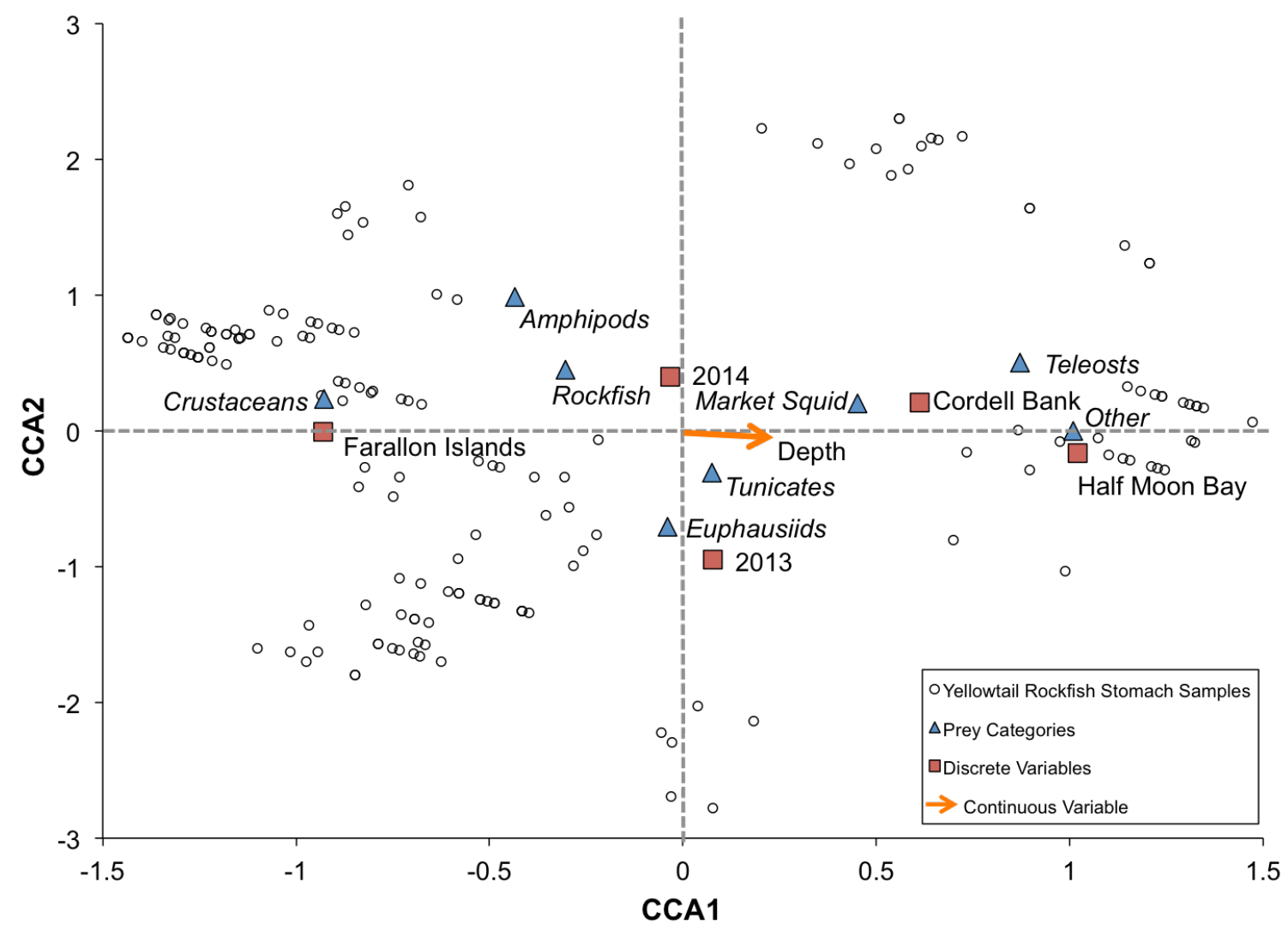

Figure 13. CCA biplot of the relationships between Yellowtail Rockfish stomach samples (black open circles), prey categories (blue triangles), and significant response variables (discrete as squares (red for Location, green for Date), and continuous as orange arrows) based on \%W in all locations and years 


\section{Stable Isotope Analysis}

White muscle tissue was extracted from 145 Yellowtail Rockfish and analyzed for stable isotopes (Table 11). Samples sizes for Cordell Bank 2013 and 2014 were less than 30 , and therefore, all tissue samples were included in the stable isotope analysis. For locations and years where more than 30 stomachs were analyzed (Farallon Islands 2013, Farallon Islands 2014 and Half Moon Bay 2014), a subset of 30 tissue samples were chosen by randomly selecting from evenly distributed length bins. Two samples from Farallon Islands in 2013 were crushed by the ISODAT, or isotope data computer program, and lost, therefore, only the results from 145 samples are reported. Total lengths for fishes analyzed ranged from $22-48 \mathrm{~cm}$ (Table 11).

\section{Table 11}

Number of Yellowtail Rockfish white muscle samples included in stable isotope analysis by location and year with associated mean total lengths and standard deviations

\begin{tabular}{c|c|c}
\hline Location and Year & $\begin{array}{c}\text { \# of white muscle } \\
\text { samples included in SIA }\end{array}$ & $\begin{array}{c}\text { Mean Total } \\
\text { Length } \pm \text { SD (cm) }\end{array}$ \\
\hline Cordell Bank 2013 & 29 & $40.5 \pm 4.0$ \\
Farallon Islands 2013 & 28 & $31.5 \pm 3.4$ \\
Cordell Bank 2014 & 28 & $40.6 \pm 4.5$ \\
Farallon Islands 2014 & 30 & $31.1 \pm 2.9$ \\
Half Moon Bay 2014 & 30 & $29.1 \pm 3.8$ \\
\hline Total & 145 & $34.5 \pm 6.2$ \\
\hline
\end{tabular}


Stable isotope signatures. Mean $\delta^{13} \mathrm{C}$, mean $\delta^{15} \mathrm{~N}$, and $\mathrm{C}: \mathrm{N}$ ratios varied by location and year. Overall, mean $\delta^{13} \mathrm{C}$ values in samples varied between $-19.0 \%$ and $-16.3 \%$. Mean $\delta^{15} \mathrm{~N}$ values in samples analyzed ranged from $13.1 \% 0-$ 15.5\%. The range of C:N ratios was 3.1 - 3.8 (Table 12).

Table 12

Means and standard deviations for $\delta^{13} \mathrm{C}(\%), \delta^{15} N(\%)$, and C:N for Yellowtail Rockfish white muscle tissue for all locations and years

\begin{tabular}{c|c|c|c}
\hline Location and Year & $\begin{array}{c}\text { Mean } \delta^{13} \mathbf{C} \pm \\
\text { SD }(\% \circ)\end{array}$ & $\begin{array}{c}\text { Mean } \delta^{15} \mathbf{N} \pm \\
\text { SD }(\%)\end{array}$ & $\begin{array}{c}\text { C:N Mean } \pm \\
\text { SD }\end{array}$ \\
\hline \hline Cordell Bank 2013 & $-18.5 \pm 0.3$ & $14.0 \pm 0.4$ & $3.4 \pm 0.1$ \\
Farallon Islands 2013 & $-17.5 \pm 0.3$ & $13.9 \pm 0.4$ & $3.5 \pm 0.1$ \\
Cordell Bank 2014 & $-18.0 \pm 0.4$ & $14.5 \pm 0.4$ & $3.5 \pm 0.1$ \\
Farallon Islands 2014 & $-16.9 \pm 0.3$ & $14.4 \pm 0.2$ & $3.5 \pm 0.1$ \\
Half Moon Bay 2014 & $-17.0 \pm 0.3$ & $14.8 \pm 0.3$ & $3.4 \pm 0.1$ \\
\hline Total & $-17.5 \pm 0.7$ & $14.3 \pm 0.5$ & $3.4 \pm 0.1$ \\
\hline
\end{tabular}




\section{Variability in $\delta^{13} \mathrm{C}$ and $\delta^{15} \mathrm{~N}$ based on total length, location, and year.}

Linear regressions were performed to evaluate the relationship between total length and $\delta^{13} \mathrm{C}$ and $\delta^{15} \mathrm{~N}$. Analyses indicated a significant negative relationship between $\delta^{13} \mathrm{C}$ and increasing total length of Yellowtail Rockfish $\left(R^{2}=0.44, p<\right.$ 0.0001 , Figure 14). More negative $\delta^{13} \mathrm{C}$ values can indicate a more pelagic carbon source, therefore, these data infer that larger fish are consuming more pelagic-influenced carbon sources than smaller fish. There was no significant relationship between total length and $\delta^{15} \mathrm{~N}\left(R^{2}=0.01, p=0.19\right.$, Figure 15).

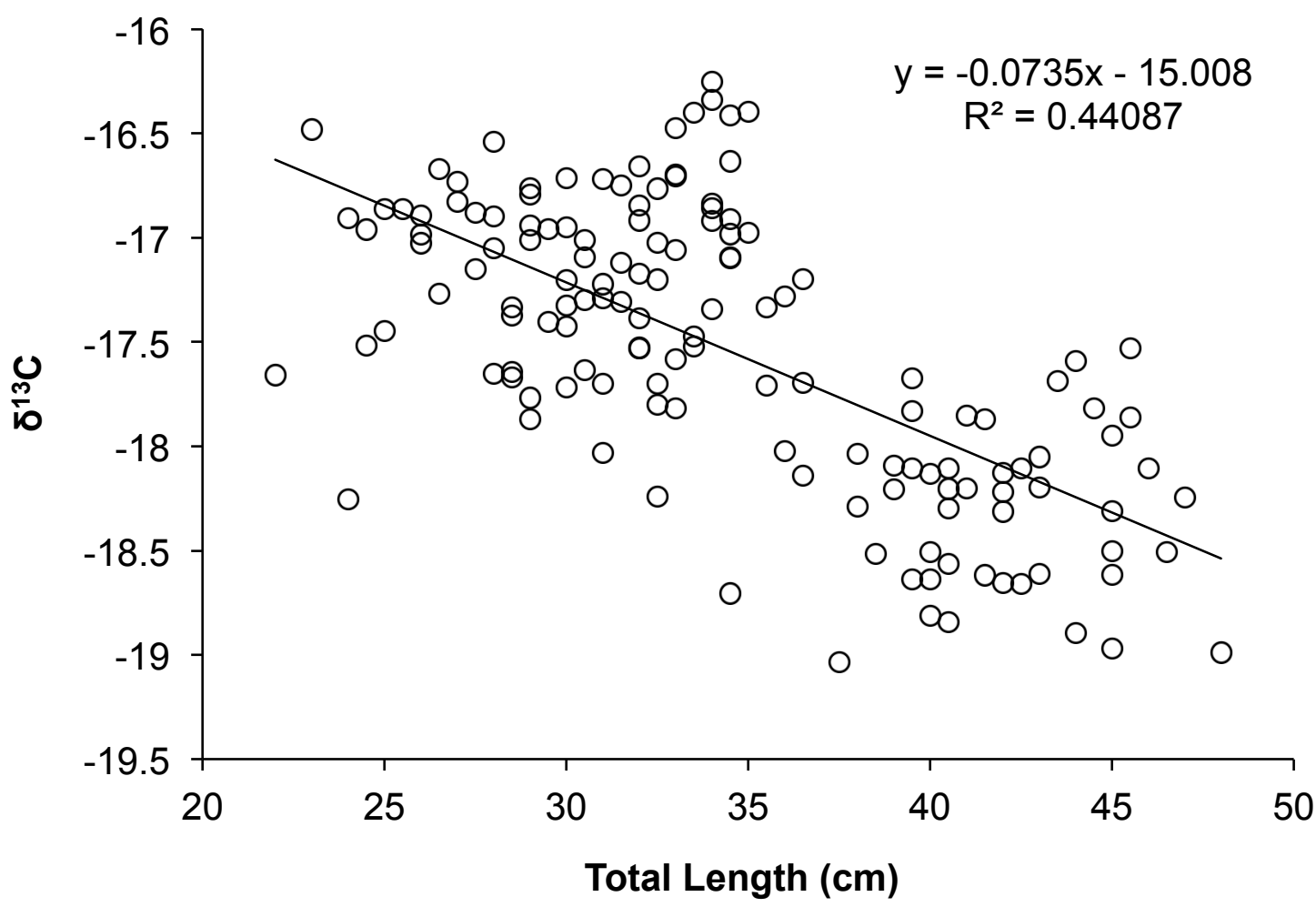

Figure 14. Yellowtail Rockfish total length $(\mathrm{cm})$ as a function of $\delta^{13} \mathrm{C}(\%)$ for all locations and years 


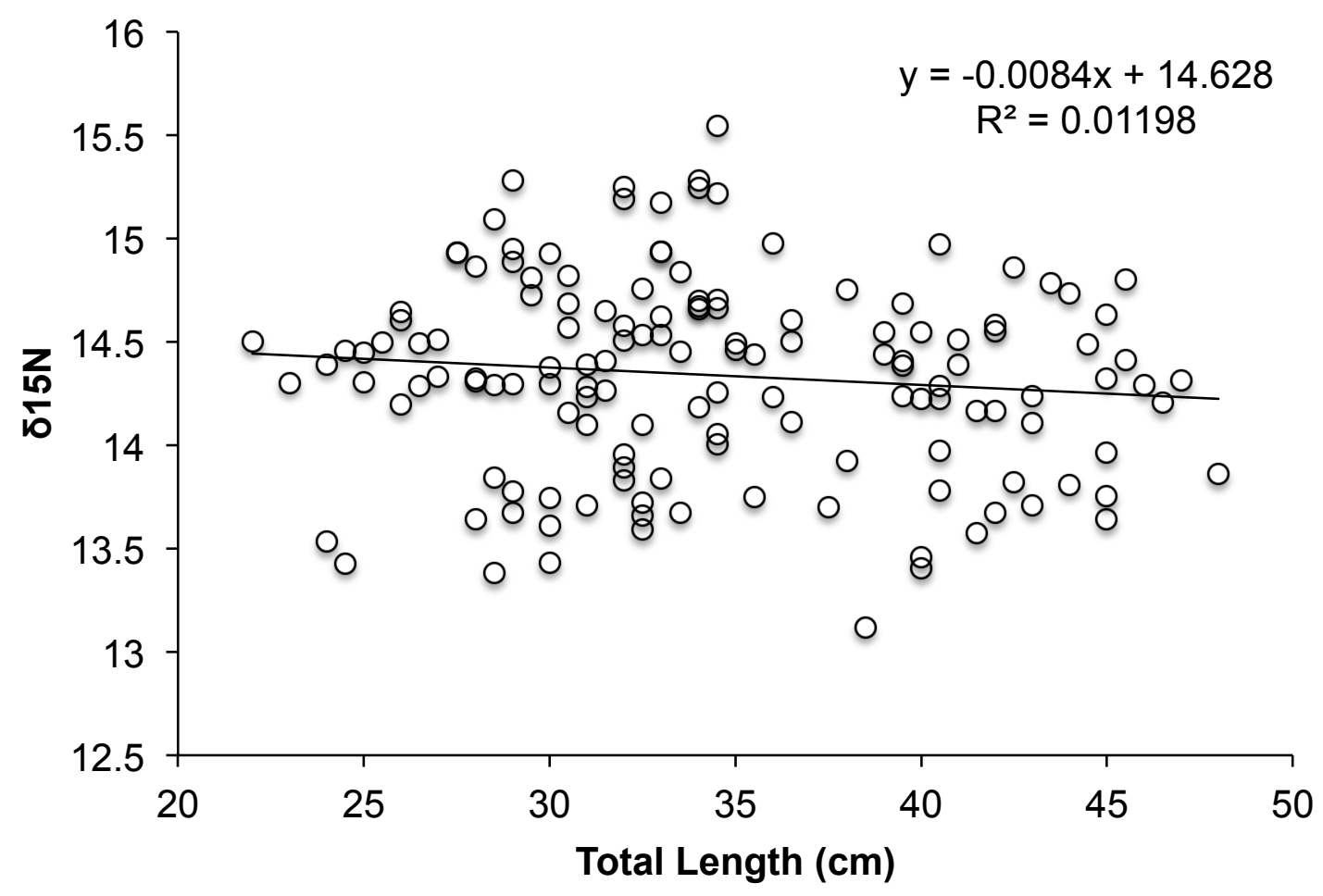

Figure 15. Yellowtail Rockfish total length $(\mathrm{cm})$ as a function of $\delta^{15} \mathrm{~N}(\%)$ for all locations and years

ANOVAs were conducted to determine if $\delta^{13} \mathrm{C}$ and $\delta^{15} \mathrm{~N}$ were significantly different based on location and year. Significant differences were evident in both $\delta^{13} \mathrm{C}\left(F_{4,145}=30.91, p=<0.0001\right.$, Figure 16$)$ and $\delta^{15} \mathrm{~N}\left(F_{4,145}=115.7, p=<\right.$ 0.0001 , Figure 17) depending on the location and year sampled. Tukey's Honest Significant Difference test was performed as a post-hoc test to determine which specific group means were statistically different. 


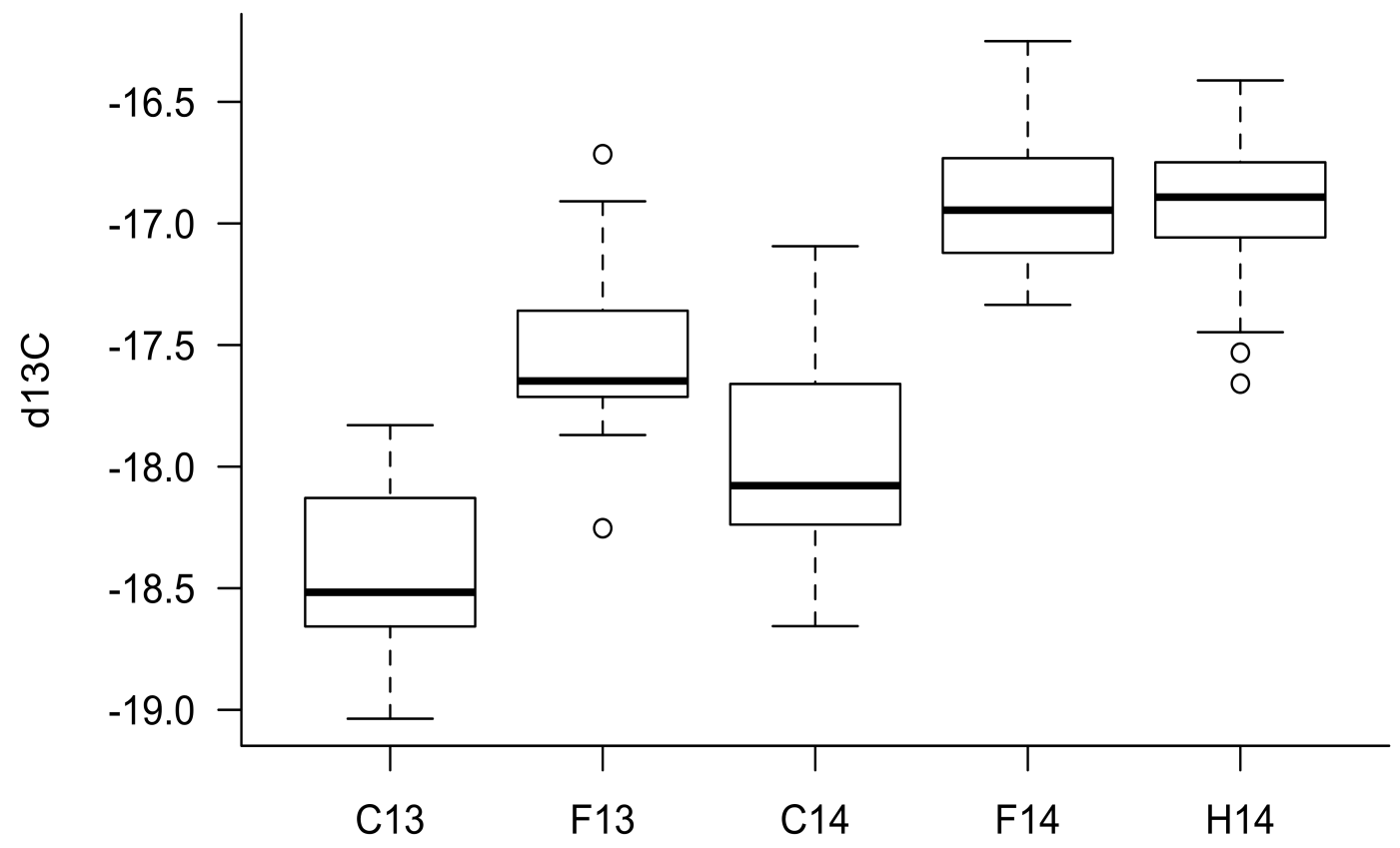

Location and Year

Figure 16. Box plot of the $\delta^{13} \mathrm{C}$ distributions of Yellowtail Rockfish white muscle tissue for all locations and years. Bolded line inside each box represents the sample mean. Horizontal lines at the top and bottom of each box are represented by $+/-1.5 *$ IQR. Open circles denote points that fall outside this range. Abbreviations: $\mathrm{C}=$ Cordell Bank, $\mathrm{F}=$ Farallon Islands, $\mathrm{H}=$ Half Moon Bay, $13=2013,14=2014$ 


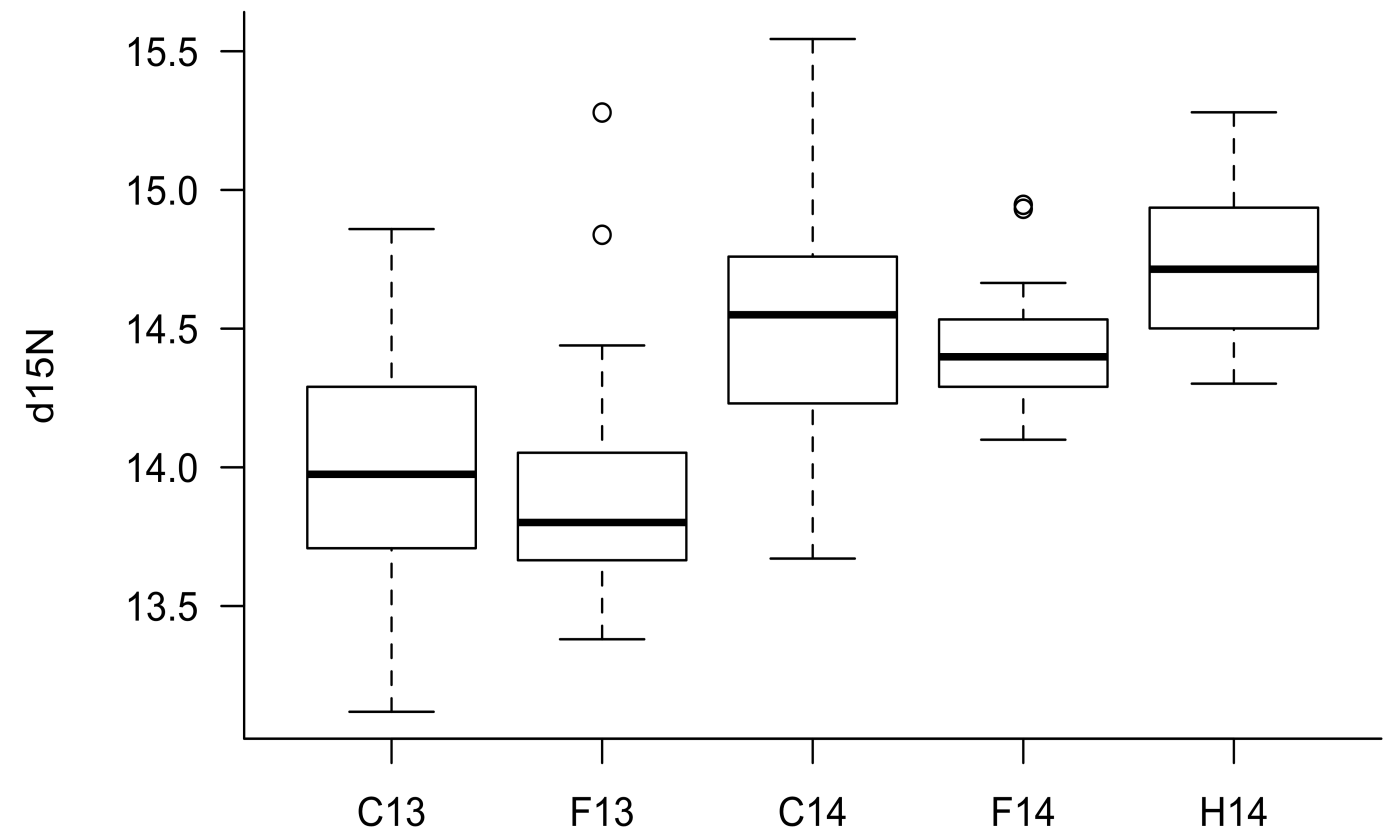

Location and Year

Figure 17. Box plot of the $\delta^{15} \mathrm{~N}$ distributions of Yellowtail Rockfish white muscle tissue for all locations and years. Bolded line inside each box represents the sample mean. Horizontal lines at the top and bottom of each box are represented by $+/-1.5 *$ IQR. Open circles denote points that fall outside this range. Abbreviations: $\mathrm{C}=$ Cordell Bank, $\mathrm{F}=$ Farallon Islands, $\mathrm{H}=$ Half Moon Bay, $13=2013,14=2014$ 
For $\delta^{13} \mathrm{C}$, there were significant differences among all locations and years, except the Farallon Islands 2014 and Half Moon Bay 2014 (Table 13). This indicated that the dietary sources of carbon varied between years for the same location, and by location within the same year. Yellowtail Rockfish white muscle $\delta^{13} \mathrm{C}$ signatures were more negative at Cordell Bank in 2013 than in 2014, suggesting a more pelagic carbon source in 2013 . The same pattern is evident for the Farallon Islands, where it appears that a more benthic carbon source was utilized in 2014. Similarly, within the same year, stomachs of Yellowtail Rockfish at Cordell Bank contained a more pelagic carbon source than fish at the Farallon Islands for both years studied.

\section{Table 13}

Summary of Tukey's Honest Significance Difference test results for $\delta^{13} \mathrm{C}$ with $p$ values to indicate signifiant differences among location/year combinations

Location/Year Combinations P-Value

Cordell Bank 2013 / Farallon Islands $2013<\mathbf{0 . 0 0 1}$

Cordell Bank 2013 / Cordell Bank 2014

$<0.001$

Cordell Bank 2013 / Farallon Islands 2014

$<0.001$

Cordell Bank 2013 / Half Moon Bay 2014

$<0.001$

Farallon Islands 2013 / Cordell Bank 2014

$<0.001$

Farallon Islands 2013 / Farallon Islands 2014

$<0.001$

Farallon Islands 2013 / Half Moon Bay 2014

$<0.001$

Cordell Bank 2014 / Farallon Islands 2014

$<0.001$

Cordell Bank 2014 / Half Moon Bay 2014

$<0.001$

Farallon Islands 2014 / Half Moon Bay 2014

0.9632 
There were significant differences between $\delta^{15} \mathrm{~N}$ signatures measured from Yellowtail Rockfish muscle at Cordell Bank 2013 and Cordell Bank 2014, Cordell Bank 2013 and the Farallon Islands 2014, Cordell Bank 2013 and Half Moon Bay 2014, the Farallon Islands 2013 and Cordell Bank 2014, the Farallon Islands 2013 and the Farallon Islands 2014, the Farallon Islands 2013 and Half Moon Bay 2014, and the Farallon Islands 2014 and Half Moon Bay 2014. Locations and years that were not statistically significant from each other for $\delta^{15} \mathrm{~N}$ were Cordell Bank 2013/the Farallon Islands 2013, Cordell Bank 2014/the Farallon Islands 2014, and Cordell Bank 2014/Half Moon Bay 2014 (Table 14).

Table 14

Summary of Tukey's Honest Significance Difference test results for $\delta^{15} \mathrm{~N}$ with $\mathrm{p}$ values to indicate signifiant differences among location/year combinations

Location/Year Combinations P-Value

Cordell Bank 2013 / Farallon Islands $2013 \quad 0.8305$

Cordell Bank 2013 / Cordell Bank 2014

$<0.001$

Cordell Bank 2013 / Farallon Islands 2014

$<0.001$

Cordell Bank 2013 / Half Moon Bay 2014

$<0.001$

Farallon Islands 2013 / Cordell Bank 2014

$<0.001$

Farallon Islands 2013 / Farallon Islands 2014

$<0.001$

Farallon Islands 2013 / Half Moon Bay 2014

$<0.001$

Cordell Bank 2014 / Farallon Islands 2014

0.8479

Cordell Bank 2014 / Half Moon Bay 2014

0.5515

Farallon Islands 2014 / Half Moon Bay 2014

0.0019 
Differences in Yellowtail Rockfish white muscle $\delta^{15} \mathrm{~N}$ can be linked to changes in the trophic level the predator is feeding at. Most notably, Yellowtail Rockfish white muscle $\delta^{15} \mathrm{~N}$ from all 2013 locations were significantly different from all 2014 locations, indicating that Yellowtail Rockfish were feeding at higher trophic levels in 2014. Within a specific year, $\delta^{15} \mathrm{~N}$ did not vary significantly, except for between the Farallon Islands and Half Moon Bay. Yellowtail Rockfish from Half Moon Bay in 2014 had the highest $\delta^{15} \mathrm{~N}$ values, on average, of all locations and years studied.

A classic way of visualizing the distribution of isotopic signatures is to plot the $\delta^{13} \mathrm{C}$ and $\delta^{15} \mathrm{~N}$ values against one another (Figure 18). Both elements combine to create a picture of nitrogen and carbon isotopes in white muscle tissue of Yellowtail Rockfish. The carbon signatures provide an indication of the source of primary productivity, and nitrogen signatures provide a sense of at what trophic level the predator is generally feeding. $\delta^{13} \mathrm{C}$ signatures are more negative for Cordell Bank and the Farallon Islands in 2013 than they are in 2014 at the same locations. Similarly, $\delta^{15} \mathrm{~N}$ signatures are more negative for both Cordell Bank and the Farallon Islands in 2013 than they are for 2014. Stable isotopes of Yellowtail Rockfish in these locations are shifting in very similar manners. These results imply that fishes caught in 2013 had more pelagic carbon dietary input, whereas those caught in 2014 had more benthic carbon dietary input. In addition, fishes caught in 2013 were generally eating at lower trophic levels than those caught in 2014. 


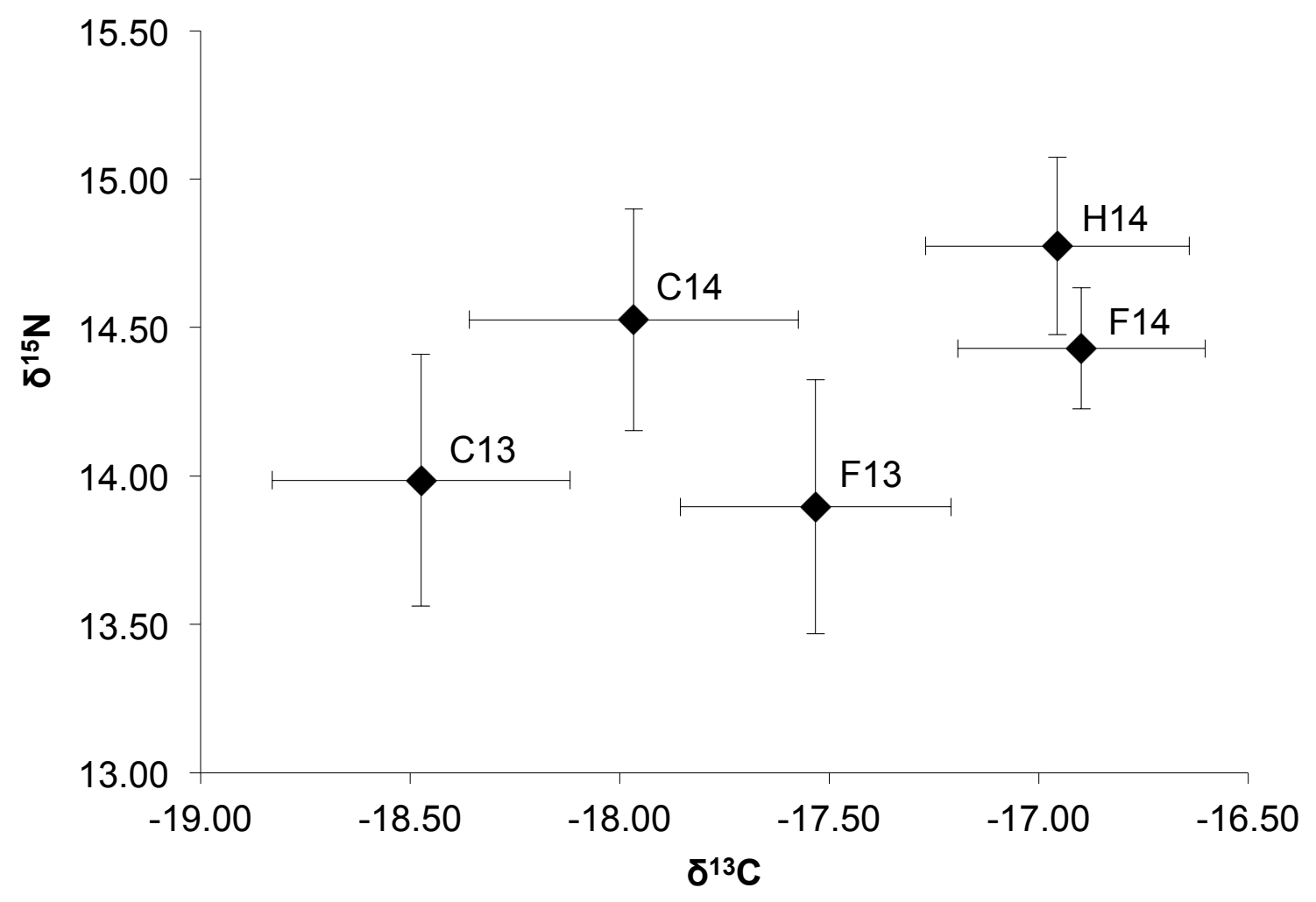

Figure 18. Relationship between Yellowtail Rockfish white muscle $\delta^{13} \mathrm{C}$ and $\delta^{15} \mathrm{~N}$ with standard deviations for all locations and years. Abbreviations: $\mathrm{C}=\mathrm{Cordell}$ Bank, F = Farallon Islands, H = Half Moon Bay, $13=2013,14=2014$. 


\section{Discussion}

The diets of some species of Sebastes are well known. The feeding strategies of rockfish species that have been studied can usually be separated into three categories: specialists (stenophagous), generalists (euryphagous) and opportunists. Gerking (1994) defined these terms with respect to the feeding ecology of fishes. The specialist category implies a diet restricted to a relatively small number of species. Generalists eat a broad spectrum of foods in terms of prey species or microhabitats in which the prey live. Specialists are more common when the food base is abundant, and generalists are more common when food is scarce. Gerking (1994) suggested that a fish species might switch from specialist to generalist during a period when food abundance declines abruptly or competition increases. Opportunistic feeders can be defined as fish species that take advantage of transitory food sources that are normally outside their usual diet. They may switch from a common food source whenever a more abundant and energetically profitable one comes along. The primary distinction between generalists and opportunists is how the species deals with transitory food sources that are advected into their feeding environment; however, many studies assume these two categorizations to be functionally similar.

Diet studies have been utilized as the basis for assigning categories of feeding strategies to numerous rockfish species. Brodeur and Pearcy (1984) characterized Canary Rockfish (Sebastes pinniger) and Darkblotched Rockfish (Sebastes crameri) off the US west coast as stenophagous because their diets 
contained very few prey items that were represented in large numbers or volumes. Similarly, China Rockfish (Sebastes nebulosus) in the Gulf of Alaska were found to be specialists with a preference for substrate-oriented prey (Rosenthal et al., 1988).

On the other end of the spectrum, Splitnose Rockfish (Sebastes diploproa) off the US west coast were characteristic of euryphagous predators whose stomachs contained high overall prey diversity as well as high within-stomach diversity (Brodeur \& Pearcy, 1984). In the Gulf of Alaska, Dusky Rockfish (Sebastes ciliatus), Puget Sound Rockfish (Sebastes emphaeus), and Quillback Rockfish (Sebastes maliger) were all considered to be dietary generalists, and respectively consumed primarily invertebrate zooplankton, epipelagic crustaceans, and a wide variety of crustacea and small fishes (Rosenthal et al., 1988).

Copper Rockfish (Sebastes caurinus) is an example of a species that has been associated with multiple different feeding strategies depending on the study. Prince and Gotshall (1976) suggested that Copper Rockfish could be best categorized as opportunistic consumers, feeding primarily on crustaceans (including juvenile Dungeness crab). Juvenile Dungeness crab utilize Humboldt Bay, CA as a nursery ground, and the abundance of this prey category in the diet of Copper Rockfish was deemed to be seasonal, being more abundant during the summer and fall rather than winter and spring. Copper Rockfish were taking advantage of a transitory food source that is only abundant during a specific time 
period, in that case, during the months when data were collected for the Prince and Gotshall (1976) study. In contrast, Murie (1995) described Copper Rockfish from Saanich Inlet in British Columbia, Canada as generalist feeders, with an emphasis that seasonality influenced the degree of dietary specialization.

Similarly, Gopher Rockfish (Sebastes carnatus) were thought to have generalist feeding tendencies (Larson, 1980), but recent research by Loury (2011) indicated that the diets of individuals can be relatively specialized compared to the population as whole. The individual specialization documented in her work was likely due to behavior plasticity coupled with prey availability, as opposed to definitive specialization shaped by evolution, resulting in considerable variation among Gopher Rockfish individuals at any given time.

Yellowtail Rockfish have been described as having all three feeding strategies, depending on when and where the study was conducted. Rosenthal et al. (1988) collected diet data on Yellowtail Rockfish in the eastern Gulf of Alaska, and concluded that this species was a dietary specialist because it fed most heavily on fishes. Brodeur and Pearcy (1984) suggested Yellowtail Rockfish from southern Oregon to Vancouver were generalists with high overall prey diversity in observed diets, as well as high within-stomach diversity. Lee and Sampson (2009) explained that patterns in their diet results were associated with geographical components, temporal components, and their interactions. The complicated interactions between geographical and temporal variables in their model for Yellowtail Rockfish diet indicated that the predation pattern for this 
species was temporally localized, and thus they should be considered an opportunistic feeder.

For a species whose diet is dependent on spatial and temporal factors, it is difficult to directly compare to previous studies. In the early 1980s, Rosenthal et al. (1988) found fishes, primarily Pacific Sand Lance, Ammodytes hexapterus, to be the most important prey item in Yellowtail Rockfish diets in the Gulf of Alaska. Although fishes were also found in the stomachs of the Yellowtail Rockfish analyzed in my study, both the proportions and species consumed were drastically different. During a similar time period in Oregon and Washington, Brodeur and Pearcy (1984) found that Yellowtail Rockfish diets were dominated by several species of Euphausiids, and adult Pacific Herring (Clupea harengus pallasi) were important on a weight basis. Again, I did see Euphausiids present in the stomachs I analyzed, primarily at Cordell Bank in 2013, but they did not dominate the diet. No Pacific Herring were found in central California stomachs. Lee and Sampson (2009) surveyed in similar locations to Brodeaur and Pearcy (1984) in the late 1990s in order to compare results between anomalous oceanographic events. Lee and Sampson (2009) saw a decrease in Euphausiids compared to Brodeur and Pearcy (1984), and an increase in gelatinous zooplankton/jellyfish species. There was also an increase in the proportion of fishes, however, the dominant species seen by Lee and Sampson (2009) was Pacific Whiting (Merluccius productus). I similarly found Euphausiids to be a less 
significant prey group, coupled with a rise in gelatinous zooplankton and fishes, although the prey species composition has considerable variability.

The results presented by Lee and Sampson (2009) and the factors for explaining variability in diet closely parallel the findings of my study. When some prey groups were more abundant in the water column, due to oceanographic processes, blooms, or increased productivity, Yellowtail Rockfish fed opportunistically on those items and did not necessarily select for specific groups. However, without prior understanding of this passive and opportunist feeding strategy, one might misconstrue this species as a specialist because only that abundant prey group was visually seen in stomachs. On any given day, prey group complexes could shift due to changing ocean conditions, thus modifying prey availability. How specialized or generalized the diet of Yellowtail Rockfish appears to be is highly dependent on temporal and spatial factors, and the oceanic dynamics associated with each.

Temporal differences were one major factor driving the variability seen among Yellowtail Rockfish diets in this study. This is particularly interesting because it showed that Yellowtail Rockfish diets within a single location were not consistent from year to year. This result suggests that diets of Yellowtail Rockfish caught in these locations may shift over relatively short time scales. Results from the final PERMANOVA models and CCA models show that Year was one of the main variables influencing the diet composition of Yellowtail Rockfish. Because Year was a significant factor in explaining the variability seen in Yellowtail Rockfish 
diets, I created a second PERMANOVA model and included Date. For Cordell Bank and the Farallon Islands in 2013, Date was the only variable that added significance to the model, and it explained far more variability than Year. In addition, there was significant variability within a single sampling date, based on a significant result from the permutation test for homogeneity of multivariate dispersion, further proving the inherent level of high variability present in this system. When put into a broader context, it is logical that Date is a significant driver of the variability seen in prey diversity. Oceanographic conditions are constantly changing and influencing the prey availability of items such as gelatinous zooplankton and juvenile fishes that were prevalent in the diet of Yellowtail Rockfish. My results indicate that diet composition of Yellowtail Rockfish is not only changing significantly between years, but also on much shorter time scales, such as weeks to months, which is the scale at which oceanographic conditions vary in central California.

Spatial variability was another major factor influencing the diets of Yellowtail Rockfish in my study. All of the locations sampled were within central California, with only slight changes in Latitude and Longitude, indicating that changes in diet were shifting over relatively small spatial scales. If a single year was selected, significant differences in prey composition were observed among locations. Furthermore, Location was a significant factor influencing the diet composition of Yellowtail Rockfish in both the final PERMANOVA and CCA models. In addition, results from the permutation tests for homogeneity of multivariate dispersions 
showed Location was significant, suggesting inherent variability within this spatial scale.

Results from the stable isotope analysis paralleled temporal and spatial trends observed with the gut content analysis. $\delta^{13} \mathrm{C}$ signatures were significantly different among all location and year combinations, with the exception of the Farallon Islands and Half Moon Bay in 2014, showing shifts on relatively small time and space scales. The $\delta^{13} \mathrm{C}$ values of high trophic level consumers are influenced by the carbon isotope composition of the food web base. In the case of these Yellowtail Rockfish caught in central California, diets in 2013 and 2014 shifted from more pelagic carbon sources, like Tunicates and Euphausiids, to more benthic carbon sources, like Amphipods and Crustaceans. With respect to Location, Yellowtail Rockfish caught at Cordell Bank contained the highest proportion of Euphausiids in their diets, which could be a driver for the more negative $\delta^{13} \mathrm{C}$ values, while those caught at the Farallon Islands had the highest proportion of Crustaceans, contributing to the more positive $\delta^{13} \mathrm{C}$ values.

Similarly, significant differences were observed in $\delta^{15} \mathrm{~N}$ signatures among locations and years. In particular, $\delta^{15} \mathrm{~N}$ signatures were more positive for Yellowtail Rockfish caught in 2014 compared to 2013, suggesting that fish caught in 2014 were eating at higher trophic levels. This correlates with the gut content analysis, which showed higher trophic level prey groups, such as Teleosts (including Rockfishes and Flatfishes), Market Squid, and Crustaceans to be more important in the diet of Yellowtail Rockfish caught in 2014. It is interesting that 
$\delta^{15} \mathrm{~N}$ signatures showed no relationship with Yellowtail Rockfish total length. One possible explanation is that the size range surveyed for this work was narrow, and captured primarily sub-adults or adults with no juveniles or large adults.

Carbon and nitrogen stable isotope signatures integrate diet inputs over many weeks to months, compared to the snapshot image of diet provided by gut content analysis. Despite this longer timeline, results from the gut content analysis and stable isotope analysis were similar, indicating that Yellowtail Rockfish diet is inherently variable and displays plasticity with respect to time and space.

Yellowtail Rockfish caught in central California between 2013 and 2014 were opportunistic feeders who consumed a wide variety of transitory pelagic prey items. Both the gut content analysis and stable isotope analysis affirmed general patterns of diet composition seen in other geographic areas, however, I was able to show how small-scale spatial and temporal factors greatly influenced dietary differences. Yellowtail Rockfish feeding ecology was highly dependent on prey availability at a particular location or within a specific time frame, indicating that food sources were transitory and were governed by factors such as oceanographic processes.

My results have implications for stock assessments, as differences in diets have been shown to have direct consequences for growth, condition, reproductive success, and survival among geographically distinct populations (Foy \& Norcross, 1999; McCormick, 2003; Wainright, Fuller, Michener, \& 
Richards, 1996). Understanding influential factors affecting diets could be useful for management for the southern stock of Yellowtail Rockfish and could be used as a proxy for predicting future population levels.

The Yellowtail Rockfish studied in this research were caught in interesting environmental years. The State of the California Current report for 2013-2014 (Leising et al., 2014) characterized 2013 as a year of lower ocean temperatures, higher salinity, and higher chlorophyll-a concentration compared to previous years. NMFS research recorded the highest ever-observed trawl catches of juvenile rockfishes, Sanddabs (Citharichthys spp.) and Market Squid. In addition, they saw high krill abundances and low abundances of Anchovy and Sardines. Salps, although high in abundance, did not reach the peak observed levels of 2012, but Pyrosome populations were the highest ever recorded in the NMFS survey. These oceanographic observations were reflected in my analyses for Yellowtail Rockfish from 2013 as Tunicates and Euphausiids were the most important contributors to the diet of Yellowtail Rockfish at both Cordell Bank and the Farallon Islands.

The State of the California Current report for 2014-2015 (Leising et al., 2015) described 2014 as the beginning of the "warm blob" phenomenon. Because of the influx of warm water, there were intrusions of new and more species along the coast, including fishes, crustaceans, tunicates, and other gelatinous zooplankton, thereby increasing species richness. Compared to 2013, 2014 was characterized by higher water temperatures and lower chlorophyll-a 
concentrations due to weak upwelling. The measure of chlorophyll-a can be used as a proxy for overall primary productivity in the water column. There were also high reported catches of juvenile rockfishes and Pacific Sanddab (Citharichthys sordidus). Krill was at or below average for all regions. Sardine and anchovy abundances also remained low, while market squid remained high. Pelagic tunicates, such as Salps, Thetys vagina, and Pyrosomes, were recorded at extreme to high record levels. My analysis of gut content data from Yellowtail Rockfish collected in 2014 also compared well with the California Current observations in 2014. Juvenile Rockfish, particularly Shortbelly Rockfish (Sebastes jordani), were prevalent in the diets, and although they were not present in high numbers, Pacific Sanddab otoliths were found. In addition, the decrease in krill observed throughout the system was also reflected in the diets of my specimens. High proportions of Market Squid remained consistent, particularly at Cordell Bank. Finally, pelagic Tunicates made up a significant part of Yellowtail Rockfish diets in 2014, on track with the abundance totals from the CalCOFI report. At Cordell Bank, all 3 groups mentioned (Salps, Thetys vagina, and Pyrosomes) were present and were the most important contributors to diet at this location. Similarly, both Salps and Pyrosomes were present at the Farallon Islands and Half Moon Bay in 2014, and also contributed significantly to the diets in their respective locations.

Yellowtail Rockfish diet trends from my study mirrored the general oceanographic trends for the entire California Current ecosystem. This implies 
that ocean conditions may be able to provide information on what prey groups are available in the water column, and therefore, what Yellowtail Rockfish are likely consuming. For instance, Salp populations are closely tied with shifting ocean conditions. Salps are asexual and their populations explode when oceanographic conditions are right (i.e., higher water temperatures). Salps as a prey group form a solid base for a food chain that feeds many fishes. If water temperatures, $\mathrm{pH}$, upwelling, etc. could be predicted, it could help predict the presence of base-level prey groups, such as Salps, which could provide an inference about how well species that eat these prey items will do. High prey availability of an important base species could lead to increased reproductive potential and recruitment. The presence of certain prey groups could also indicate strong versus weak year classes, which would help resource managers predict how well the stock would perform in subsequent years. 


\section{Conclusion}

Ecosystem-based fisheries management is the goal in the mind of most modern resource managers. The importance of ecosystem interactions and connections can no longer be overlooked as factors such as climate change and overfishing continue to affect our oceans. However, an ecosystem approach is only as strong as the species-specific data that goes into it, making the demand for sound single-species assessments of life history traits still relevant. In particular, studying the diet of a single species not only gives the researcher an idea of the prey contributing to that individual food web, but also gives a sense of how that species fits in to the regional, coastal, and global context. In a sense, evaluating diet already begins the drive toward an ecosystem approach, making it an important and relevant contributor to fisheries research.

By analyzing the diet of Yellowtail Rockfish, I have filled data gaps in time and predator-prey relationships, and provided information for future ecosystem models. Relating diet data to stable isotope ratios has provided a more robust depiction of what Yellowtail Rockfish in central California consumed in the years 2013 and 2014. In addition, identifying 'Date', or more importantly, short time scales, as a significant driving factor in the variability of Yellowtail Rockfish diets in some locations identifies the scale on which diets could be shifting. As a species that preys on organisms highly influenced by changing oceanographic conditions, it is also important to consider rises in temperature, changes in 
upwelling patterns, and other products of climate change when evaluating the role Yellowtail Rockfish play in the ecosystem. 


\section{Literature Cited}

Adams, P.B. (1982). Feeding behavior of the Widow Rockfish (Sebastes entomelas), a diurnally feeding rockfish. Fish Food Habit Studies, proceedings, third Pacific workshop, December 6-9, 1981, Asilomar Conference Center, Pacific Grove, CA, 198-204.

Ainley, D., P. Adams, J. Jahncke. (2014). Towards ecosystem-based fishery management in the California current system - Predators and the preyscape: A Workshop. Unpublished report to the National Fish and Wildlife Foundation.

Allen, L.G., D.J. Pondella II, M.H. Horn. (2006). The ecology of marine fishes: California and adjacent waters. Berkeley, CA: University of California Press.

Amundsen, P.A., H.M. Gabler, F.J. Staldvik. (1996). A new approach to graphical analysis of feeding strategy from stomach contents data - modification of the Costello (1990) method. Journal of Fish Biology, 48: 607-614.

Anderson, M.J. (2001). Permutation tests for univariate or multivariate analysis of variance and regression. Can. J. Fish. Aquat. Sci., 58: 626-639.

Anderson, M.J., K.E. Ellingsen, B.H. McArdle. (2006). Multivariate dispersion as a measure of beta diversity. Ecol Lett, 9: 683-693.

Bearhop, S., C.E. Adams, S. Waldron, R.A. Fuller, H. Macleod. (2004).

Determining trophic niche width: a novel approach using stable isotope analysis. Journal of Animal Ecology, 73: 1007-1012.

Bigg, M.A., M.A. Perez. (1985). Modified volume: a frequency-volume method to assess marine mammal food habits. Marine Mammals and Fisheries, 277-283.

Bigman, J.S. (2013). Trophic ecology of North Pacific Spiny Dogfish (Squalus suckleyi) off central California waters. MS Thesis, Moss Landing Marine Laboratories, Moss Landing, CA.

Bizzarro, J.J., H.J. Robinson, C.S. Rinewalt, D.A. Ebert. (2007). Comparative feeding ecology of four sympatric skate species off central California, USA. Environ Biol Fish, 80: 197-220. 
Bizzarro, J.J., W.D. Smith, F. Márquez-Farías, J. Tyminski, R.E. Hueter. (2009). Temporal variation in the artisanal elasmobranch fishery of Sonora, Mexico. Fisheries Research, 97: 103-117.

Boecklen, W.J., C.T. Yarnes, B.A. Cook, A.C. James. (2011). On the use of stable isotopes in trophic ecology. Annual Review of Ecology, Evolution, and Systemics, 42: 411-440.

Bray, J.R., J.T. Curtis. (1957). An ordination of upland forest communities of southern Wisconsin. Ecol Monogr, 27: 325-349.

Brodeur, R.D., W.G. Pearcy. (1984). Food habits and dietary overlap of some shelf rockfishes (genus Sebastes) from the northeastern Pacific Ocean. Fishery Bulletin, 82(2): 269-293.

Brown, S.C. (2010). Diet composition of Bathyraja Interrupta (Gill and Townsend, 1897) and Bathyraja Aleutica (Gilbert, 1896), from the northern Gulf of Alaska continenal shelf. MS Thesis, Moss Landing Marine Laboratories, Moss Landing, CA.

Brown, S.C., J.J. Bizzarro, G.M. Cailliet, D.A. Ebert. (2012). Breaking with tradition: redefining measures for diet description with a case study of the Aleutian skate Bathyraja aleutica (Gilbert 1896). Environ Biol Fish, 95:320.

Carlton, J.T. (2007). The Light and Smith Manual: Intertidal invertebrates from central California to Oregon, fourth edition, completely revised and expanded. Berkeley, CA: University of California Press.

Chelton, D.B., P.A. Bernal, J.A. McGowan. (1982). Large-scale interannual physical and biological interaction in the California current. Journal of Marine Research, 40:1095-1125.

Cortés, E. (1997). A critical review of methods of studying fish feeding based on analysis of stomach contents: application to elasmobranch fishes. Can J. Fish Aquat. Sci, 54: 726-738.

Cope, J., E.J. Dick, A. MacCall, M. Monk, B. Soper, C. Wetzel. (2015). Datamoderate stock assessments for Brown, China, Copper, Sharpchin, Stripetail, and Yellowtail Rockfishes and English and Rex Soles in 2013. Pacific Fishery Management Council, http://www.pcouncil.org/wpcontent/uploads/Data-Moderate_Assessments_2013_FINAL_160116.pdf. 
Davis, A.M., M.L. Blanchette, B.J. Pusey, T.D. Jardine, R.G. Pearson. (2012). Gut content and stable isotope analyses provide complementary understanding of ontogenetic dietary shifts and trophic relationships among fishes in a tropical river. Freshwater Biology, 57(10): 2156-2172.

DeNiro, M.J., S. Epstein. (1978). Influence of diet on the distribution of carbon isotopes in animals. Geochimica et Cosmochimica Acta, 42: 495-506.

Ebert, D.A., J.J. Bizzarro. (2007). Standardized diet compositions and trophic levels of skates (Chondrichthyes: Rajiformes: Rajoidei). Environ Biol Fish, 80: 221-237.

Eschmeyer, W.N., E.S. Herald, H. Hammann. (1983). A field guide to the Pacific coast fishes of North America from the Gulf of Alaska to Baja California. Boston, MA: Houghton Mifflin Co.

Ferry, L.A., G.M. Cailliet. (1996). Sample size and data analysis: are we characterizing and comparing diet properly? Gutshop, 96: 71-80.

Field, J.C., R.C. Francis. (2006). Considering ecosystem-based fisheries management in the California current. Marine Policy, 30: 552-569.

Field, J.C., S. Ralston. (2005). Spatial variability in rockfish (Sebastes spp.) recruitment events in the California Current System. Can. J. Fish. Aquat. Sci., 62: 2199-2210.

Foy, R.J., B.L. Norcross (1999). Spatial and temporal variability in the diet of juvenile Pacific herring (Clupea pallasi) in Prince William Sound, Alaska. Can J Fish Aquat Sci, 77: 697-706.

France, R.L. (1995). Differentiation between littoral and pelagic food webs in lakes using carbon isotopes. Limnology and Oceanography, 40: 13101313.

Fry, B., C. Arnold. (1982). Rapid ${ }^{13} \mathrm{C} /{ }^{12} \mathrm{C}$ turnover during growth of brown shrimp (Penaeus aztecus). Oecologia. 54: 200-204.

Gerking, S.D. (1994). Feeding ecology of fish. San Diego, CA: Academic Press.

Hallacher, L.E., D.A. Roberts. (1985). Differential utilization of space and food by the inshore rockfishes (Scorpaenidae: Sebastes) of Carmel Bay, California. Environmental Biology of Fishes, 12(2): 91-110. 
Hart, J.L. (1975). Pacific Fishes of Canada. Fisheries Research Board of Canada, Bulletin 180.

Hesslein, R.H., K.A. Hallard, P. Ramlal. (1993). Replacement of sulfur, carbon, and nitrogen, in tissue of growing broad whitefish (Coregonus nasus) in response to a change in diet traced by $\delta^{34} \mathrm{~S}, \delta^{13} \mathrm{C}$, and $\delta^{15} \mathrm{~N}$. Can J Fish Aquat Sci, 50: 2071-2076.

Hopkins, J.B. III, J.M. Ferguson. (2012). Estimating the diets of animals using stable isotopes and a comprehensive Bayesian mixing model. PLOS ONE, 7(1): e28478.

Hussey, N.E., S.F.J. Dudley, I.D. McCarthy, G. Cliff, A.T. Fisk (2011). Stable isotope profiles of large marine predators: viable indicators of trophic position, diet, and movement in sharks? Canadian Journal of Fisheries and Aquatic Sciences, 68(12): 2029-2045.

Hynes, H.B.N. (1950). The food of freshwater sticklebacks (Gasterosteus aculeatus and Pygosteus pungitius) with a review of methods used in studies of the food of fishes. J. Anim. Ecol., 19: 36-58.

Hyslop, E.J. (1980). Stomach contents analysis—a review of methods and their application. J. Fish Biol. 17: 411-429.

Kemper, J.M. (2012). Food habits and trophc ecology of two common skates, Bathyraja interrupta and Raja rhina, in Prince William Sound, Alaska. MS Thesis, Moss Landing Marine Laboratories, Moss Landing, CA.

Kemper, J.M., J.J. Bizzarro, D.A. Ebert. (2017). Dietary variability in two common Alaskan skates (Bathyraja interrupta and Raja rhina). Mar Biol, 164: 52.

Laidig, T.E. (2010). Influence of ocean conditions on the timing of early life history events for blue rockfish (Sebastes mystinus) off California. Fish Bull, 108: 442-449.

Laidig, T.E., J.R. Chess, D.F. Howard. (2007). Relationship between abundance of juvenile rockfishes (Sebastes spp.) and environmental variables documented off northern California and potential mechanisms for the covariation. Fish. Bull. (Washington, D.C.), 105: 39-48.

Larson, R.J. (1980). Territorial behavior of the Black and Yellow Rockfish and Gopher Rockfish (Scorpaenidae, Sebastes). Mar Biol, 58: 111-122. 
Lee, Y.W., D.B. Sampson. (2009). Dietary variations in three co-occurring rockfish species off the Pacific Northwest during anomalous oceanographic events in 1998 and 1999. Fish. Bull., 107: 510-522.

Legendre, P., E. Gallagher. (2001). Ecologically meaningful transformations for ordination of species data. Oecologia, 129: 271-280.

Legendre, P., L. Legendre. (1998). Numerical Ecology. Amsterdam, Elsevier Science BV, pp 853.

Leising, A. W., I. D. Schroeder, S. J. Bograd, E. Bjorkstedt, J.Field, K. Sakuma, J. Abell, R. R. Robertson, J. Tyburczy, W. Peterson, R. D. Brodeur, C. Barcelo, T. D. Auth, E. A. Daly, G. S. Campbell, J. A. Hildebrand, R. M. Suryan, A. J. Gladics, C. A. Horton, M. Kahru, M. Manzano-Sarabia, S. McClatchie, E. D. Weber, W. Watson, J. A. Santora, W. J. Sydeman, S. R. Melin, R. L. DeLong, J. Largier, S. Yong Kim, F. P. Chavez, R. T. Golightly, S. R. Schneider, P. Warzybok, R. Bradley, J. Jahncke, J. Fisher, and J. Peterson. (2014). State of the California Current 2013-14: El Niño looming. CalCOFI Rep., 55: 51-87.

Leising, A.W., I.D. Schroeder, S.J. Bograd, J. Abell, R. Durazo, G. GaxiolaCastro, E.P. Bjorkstedt, J. Field, K. Sakuma, R.R. Robertson, R. Goericke, W.T. Peterson, R.D. Brodeur, C. Barceló, T.D. Auth, E.A. Daly, R.M. Suryan, A.J. Gladics, J.M. Porquez, S. McClatchie, E.D. Weber, W. Watson, J.A. Santora, W.J. Sydeman, S.R. Melin, F.P. Chavez, R.T. Golightly, S.R. Schneider, J. Fisher, C. Morgan, R. Bradley, P. Warybok. (2015). State of the California Current 2014-15: Impacts of the warm-water "blob". CalCOFI Rep., 56: 31-69.

Loury, E. (2011). Diet of the Gopher Rockfish (Sebastes carnatus) inside and outside of marine protected areas in central California. MS thesis, Moss Landing Marine Laboratories, Moss Landing, CA.

Love, M.S. (2011). Certainly More Than You Want to Know About the Fishes of the Pacific Coast. Santa Barbara, CA: Really Big Press, 236-237.

MacNeil, M.A., G.B. Skomal, A.T. Fisk. (2005). Stable isotopes from multiple tissues reveal diet switching in sharks. Mar. Ecol. Prog. Ser., 302: 199206.

Madigan, D.J., S.Y. Litvin, B.N Popp, A.B. Carlisle, C.J. Farwell, B.A. Block. (2012). Tissue Turnover Rates and Isotopic Trophic Discrimination Factors in the Endothermic Teleost, Pacific Bluefin Tuna (Thunnus orientalis). PLOS ONE, 7(11): e49220. 
Marks, C.I., R.T. Fields, R.M. Starr, J.C. Field, R.R. Miller, S.G. Beyer, S.M. Sogard, D. Wilson-Vandenberg, D. Howard. (2015). Changes in size composition and relative abundance of fishes in central California after a decade of spatial fishing closures. CalCOFI rep., 56: 1-14.

McCormick, M.I. (2003). Consumption of coral propagules after mass spawning enhances larval quality of damselfish through maternal effects. Oecologia, 136: 37-45.

McGowan, J.A., D.R. Cayan, L.M. Dorman. (1998). Climate, ocean variability and ecosystem response in the Northeast Pacific. Science, 281: 210-217.

Meier-Augenstein, W., H.F. Kemp. (2012). Stable isotope analysis: General principles and limitations. Wiley Encyclopedia of Forensic Science.

Melville, A.J., R.M. Connolly. (2003). Spatial analysis of stable isotope data to determine primary sources of nutrition for fish. Oecologia, 136: 499-507.

Miller, D.J., R.N. Lea. (1972). Guide to the coastal marine fishes of California. Fish Bulletin No. 157, California Department of Fish and Game, Sacramento, CA.

Morris, R.H., D.L. Abbott, E.C. Haderlie. (1980) Intertidal invertebrates of California. Stanford, CA: Stanford University Press.

Murie, D.J. (1995). Comparative feeding ecology of two sympatric rockfish congeners, Sebastes caurinus (Copper Rockfish) and S. maliger (Quillback Rockfish). Marine Biology, 124: 341-353.

Nagtegaal, D.A. (1983). Identification and description of assemblages of some commercially important rockfishes (Sebastes spp.) off British Columbia. Can. Dep. Fish. Oceans, Can. Tech. Rep. Fish. Aquat. Sci., 1183: 82.

National Marine Fisheries Service (NMFS). (2013). Groundfish essential fish habitat synthesis: a report to the Pacific Fishery Management Council. http://www.pcouncil.org/wp-content/ uploads/Groundfish_EFH_Synthesis _Report_to_PFMC_FINAL.pdf.

Oksanen, J., F.G. Blanchet, R. Kindt, P. Legendre, R.B. O'Hara, G.L. Simpson, P. Solymos, M. Henry, H. Stevens, H. Wagner. (2013). Vegan: community ecology package. R package version 3.3.2. Available from https://cran.rproject.org/web/packages/vegan/index.html. 
O'Leary, M.H. S. Madhavan, P. Paneth. (1992). Physical and chemical basis of carbon isotope fractionation in plants. Plant, Cell and Environment, 15: 1099-1104.

Pacific Fishery Management Council (PFMC). (2016). Terms of reference for the groundfish and coastal pelagic species stock assessment review process for 2017-2018. Pacific Fishery Management Council.

Parrish, R., C.S. Nelson, A. Bakun. (1981). Transport mechanisms and reproductive success of fishes in the California current. Biological Oceanography, 1:2, 175-203.

Perkins, M.J., R.A. McDonald, F.J.F. van Veen, S.D. Kelly, G. Rees, S. Bearhop. (2014). Application of Nitrogen and Carbon Stable Isotopes ( $\delta 15 \mathrm{~N}$ and ס13C) to Quantify Food Chain Length and Trophic Structure. PLoS ONE, 9(3): e93281.

Peterson. B.J., B. Fry. (1987). Stable isotopes in ecosystem studies. Ann. Rev. Ecol. Syst., 18: 293-320.

Pinkas, L.M., S. Oliphant, I.L.K. Iverson. (1971). Food habits of Albacore, Bluefin Tuna and Bonito in Californian waters. California Department of Fish and Game, 152: 1-105.

Post, D.M. (2002). Using stable isotopes to estimate trophic position: models, methods, and assumptions. Ecology, 83(3): 703-718.

Post, D.M., C.A. Layman, D.A. Arrington, G. Takimoto, J. Quattrochi, C.G. Montaña. (2007). Getting to the fat of the matter: models, methods and assumptions for dealing with lipids in stable isotope analyses. Oecologia, 152: $179-189$.

Prince, E.D., D.W. Gotshall. (1976). Food of the Copper Rockfish Sebastes caurinus Richardson, associated with an artificial reef in south Humboldt Bay, California. Calif. Fish and Game, 62(4): 274-283.

Ralston, S. (2001). California's Living Marine Resources: A Status Report Yellowtail Rockfish. Calif. Dept. Fish and Game, 372-373.

Ralston, S., I.J. Stewart. (2013). Anomalous distributions of pelagic juvenile rockfish on the U.S. west coast in 2005 and 2006. Calif. Coop. Ocean Fish Invest. Rep., 54: 155-166. 
Rogers, J.B., E.K. Pikitch. (1992). Numerical definition of groundfish assemblages caught off the coasts of Oregon and Washington using commercial fishing strategies. Can. J. Fish. Aquat. Sci., 49: 2648-2656.

Rosenthal, R.J., V. Moran-O'Connell, M.C. Murphy. (1988). Feeding ecology of ten species of rockfishes (Scorpaenidae) from the Gulf of Alaska. Calif. Fish and Game, 74(1): 16-37.

Rounick, J.S., M.J. Winterbourn. (1986). Stable carbon isotopes and carbon flow in ecosystems. BioScience, 36: 171-177.

Stephens, A., I.G. Taylor. (2018). Status of Yellowtail Rockfish (Sebastes flavidus) along the U.S. Pacific coast in 2017. Pacific Fishery Management Council, https://www.pcouncil.org/wp- content/uploads/2018/01/2017_ Final.pdf.

Sweeting, C.J., J.T. Barry, N.V.C. Polunin, S. Jennings. (2007). Effects of body size and environment on diet-tissue $\delta^{13} \mathrm{C}$ fractionation in fishes. Journal of Experimental Marine Biology and Ecology. 352: 165-176.

Tagart, J.V. (1987). Description of the Washington State fishery for widow rockfish. Widow rockfish proceedings of a workshop, Tiburon, CA, December 11-12, 1980, U.S. Dept. Commerce, NOAA Tech. Rep., 48: 57.

Tagart, J.V. (1991). Population dynamics of Yellowtail Rockfish (Sebastes flavidus) in the northern California to southwest Vancouver Islands region. Ph.D. thesis, University of Washington, Seattle.

ter Braak, C.J., P. Smilauer. (2002). CANOCO reference manual and CanoDraw for windows user's guide: software for canonical community ordination (version 4.5). Ithica, NY: Microcomputer Power.

Wainright, S.C., C.M. Fuller, R.H. Michener, R.A. Richards. (1996). Spatial variation of trophic position and growth rate of juvenile striped bass (Morone saxatilis) in the Delaware River. Can J Fish Aquat Sci, 53: 685692.

Wallace, J., H.L. Lai. (2005). Status of the Yellowtail Rockfish in 2004. Pacific Fishery Management Council, https://www.pcouncil.org/wpcontent/uploads/Yellowtail_Rockfish_Final_0506.pdf.

Windell, J.T. (1968). Food analysis and rate of digestion in Methods for Assessment of Fish Production in Fresh Waters, $1^{\text {st }}$ Edition. Oxford: Blackwell Scientific Publications, 197-203. 
Windell, J.T., S.H. Bowen. (1978). Methods of the Assessment of Fish Production in Fresh Waters, $3^{\text {rd }}$ Edition. Oxford: Blackwell Scientific Publications, 219-226. 


\section{APPENDIX}

Appendix 1. Diet composition tables of Yellowtail Rockfish caught in 3 central California locations in 2013 and 2014.

Diet composition at the lowest taxonomic level of Yellowtail Rockfish caught at Cordell Bank in 2013 ( $n=33$ stomachs).

\begin{tabular}{|c|c|c|c|c|c|c|c|}
\hline \multicolumn{2}{|l|}{ Lowest Taxonomic Level } & $\% \mathrm{~N}$ & $\% \mathrm{PN}$ & $\% W$ & $\% \mathrm{PW}$ & $\% \mathrm{FO}$ & $\%$ PSIRI \\
\hline \multicolumn{8}{|l|}{ Chordata } \\
\hline \multicolumn{8}{|l|}{ Actinopterygii } \\
\hline & Sebastes spp. & 3.03 & 100.00 & 3.03 & 100.00 & 3.03 & 3.03 \\
\hline & Sebastes jordani & 8.15 & 44.80 & 15.47 & 85.07 & 18.18 & 11.81 \\
\hline & Unidentified fishes & 14.05 & 51.51 & 23.75 & 87.10 & 27.27 & 18.90 \\
\hline \multicolumn{8}{|l|}{ Tunicata } \\
\hline & Salpidae spp. & 29.10 & 87.31 & 20.46 & 61.38 & 33.33 & 24.78 \\
\hline \multicolumn{8}{|l|}{ Arthropod } \\
\hline \multicolumn{8}{|l|}{ Crustacea } \\
\hline & Euphausiacea & 35.12 & 77.26 & 30.22 & 66.48 & 45.45 & 32.67 \\
\hline & Amphipoda & 1.04 & 17.13 & 0.01 & 0.15 & 6.06 & 0.52 \\
\hline \multicolumn{2}{|r|}{ Hyperiidea } & 1.01 & 33.33 & 0.01 & 0.28 & 3.03 & 0.51 \\
\hline & Crangon & 2.02 & 66.67 & 0.02 & 0.78 & 3.03 & 1.02 \\
\hline & Unidentified crustaceans & 5.48 & 25.82 & 4.02 & 18.97 & 21.21 & 4.75 \\
\hline \multicolumn{8}{|l|}{ Mollusc } \\
\hline \multicolumn{8}{|l|}{ Cephalopoda } \\
\hline & Doryteuthis opalescens & 1.01 & 33.33 & 3.01 & 99.22 & 3.03 & 2.01 \\
\hline
\end{tabular}


Diet composition at the lowest taxonomic level of Yellowtail Rockfish caught at the Farallon Islands in 2013 ( $n=41$ stomachs).

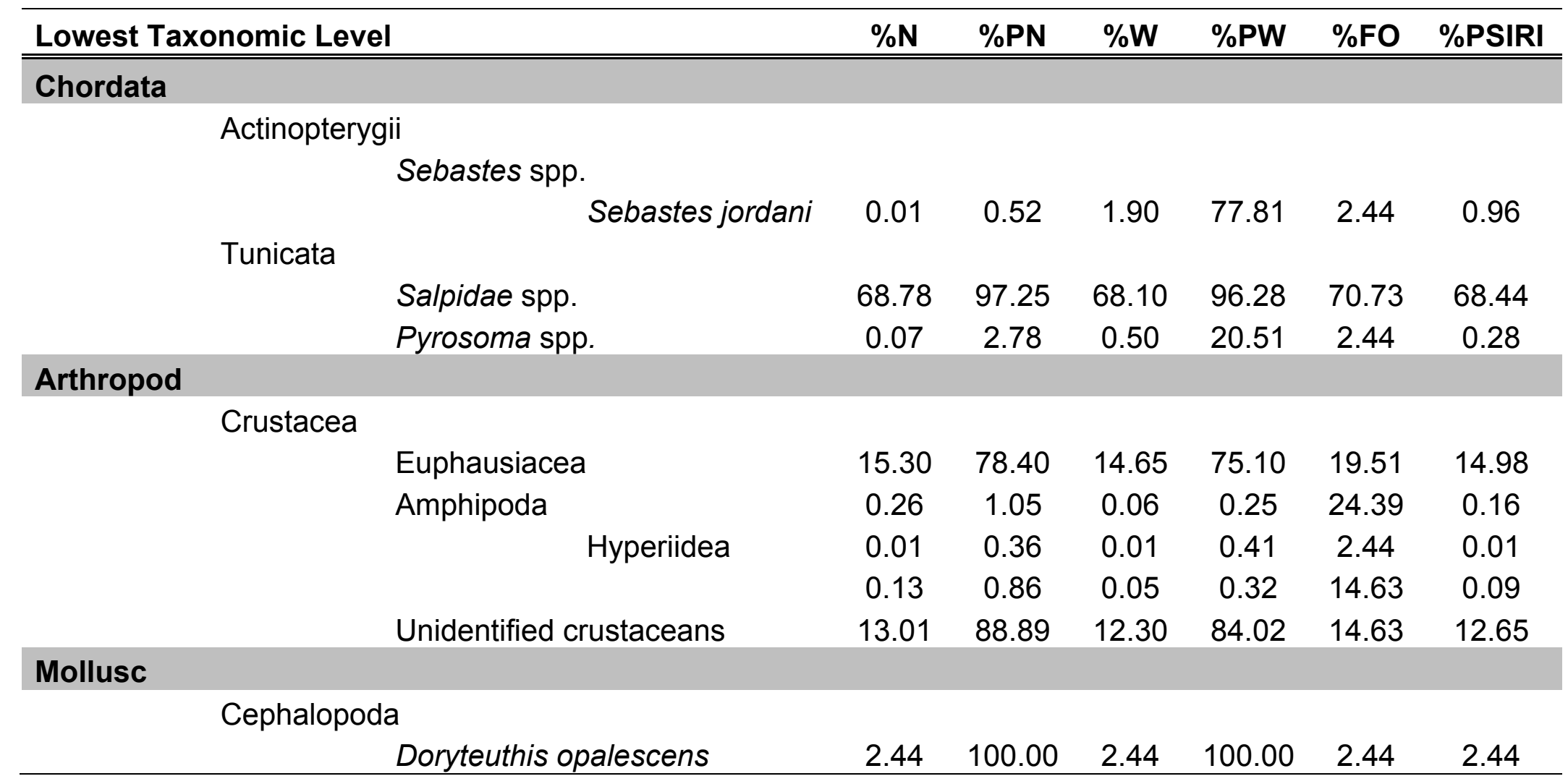


Diet composition at the lowest taxonomic level of Yellowtail Rockfish caught at Cordell Bank in 2014 ( $n=28$ stomachs).

\begin{tabular}{|c|c|c|c|c|c|c|c|}
\hline Lowest Taxonomic Level & & $\% \mathbf{N}$ & $\%$ PN & $\% \mathrm{~W}$ & $\% \mathrm{PW}$ & $\%$ FO & \%PSIRI \\
\hline \multicolumn{8}{|l|}{ Chordata } \\
\hline \multicolumn{8}{|l|}{ Actinopterygii } \\
\hline & Citharichthys sordidus & 7.14 & 100.00 & 7.14 & 100.00 & 7.14 & 7.14 \\
\hline & Unidentified fishes & 13.10 & 73.33 & 16.85 & 94.36 & 17.86 & 14.97 \\
\hline \multicolumn{8}{|l|}{ Tunicata } \\
\hline & Salpidae spp. & 9.29 & 65.00 & 9.62 & 67.33 & 14.29 & 9.45 \\
\hline & Pyrosoma spp. & 0.14 & 14.29 & 100.00 & 14.29 & 100.00 & 14.29 \\
\hline & Thetys vagina & 2.50 & 35.00 & 1.64 & 22.99 & 7.14 & 2.07 \\
\hline \multicolumn{8}{|l|}{ Arthropod } \\
\hline \multicolumn{8}{|l|}{ Crustacea } \\
\hline & Euphausiacea & 15.32 & 85.80 & 11.04 & 61.84 & 17.86 & 13.18 \\
\hline & Amphipoda & 14.29 & 66.67 & 13.63 & 63.60 & 21.43 & 13.96 \\
\hline & Hyperiidea & 1.79 & 50.00 & 0.95 & 26.55 & 3.57 & 1.37 \\
\hline & Crangon & 3.57 & 100.00 & 3.57 & 100.00 & 3.57 & 3.57 \\
\hline & Unidentified crustaceans & 0.71 & 20.00 & 0.02 & 0.44 & 3.57 & 0.36 \\
\hline \multicolumn{8}{|l|}{ Mollusc } \\
\hline \multicolumn{8}{|l|}{ Cephalopoda } \\
\hline & Doryteuthis opalescens & 14.44 & 80.87 & 17.68 & 99.01 & 17.86 & 16.06 \\
\hline \multicolumn{8}{|l|}{ Annelida } \\
\hline Polychaeta & & 3.57 & 100.00 & 3.57 & 100.00 & 3.57 & 3.57 \\
\hline
\end{tabular}


Diet composition at the lowest taxonomic level of Yellowtail Rockfish caught at the Farallon Islands in 2014 ( $n=77$ stomachs).

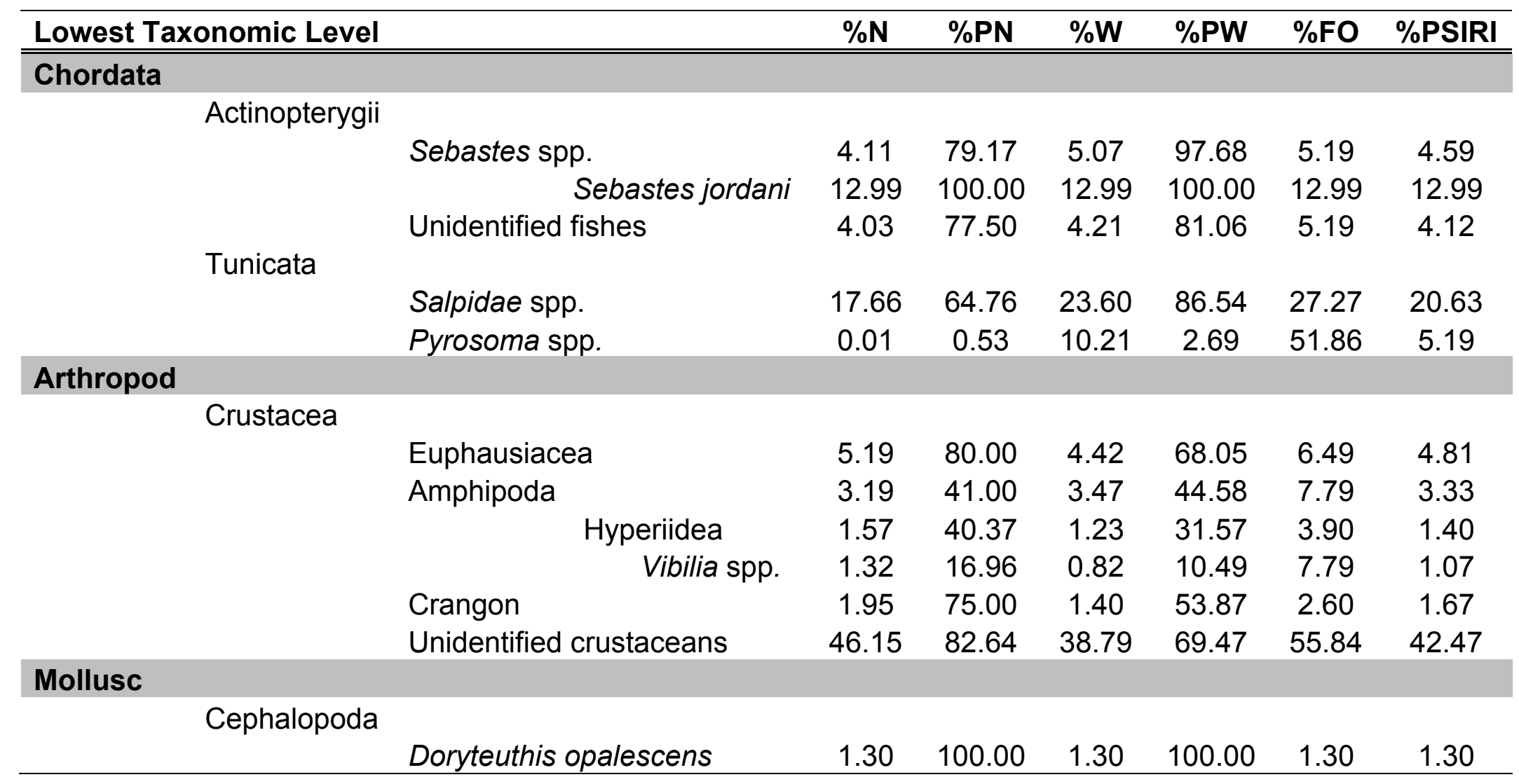


Diet composition at the lowest taxonomic level of Yellowtail Rockfish caught at Half Moon Bay in 2014 ( $n=72$ stomachs).

\begin{tabular}{|c|c|c|c|c|c|c|c|}
\hline Lowest Taxonomic Level & & $\% \mathrm{~N}$ & $\% \mathrm{PN}$ & $\% W$ & $\% \mathrm{PW}$ & $\% \mathrm{FO}$ & \%PSIRI \\
\hline \multicolumn{8}{|l|}{ Chordata } \\
\hline Actinopterygii & & & & & & & \\
\hline & Unidentified fishes & 24.62 & 73.86 & 25.54 & 76.62 & 33.33 & 25.08 \\
\hline & Salpidae spp. & 40.72 & 86.23 & 35.67 & 75.54 & 47.22 & 38.20 \\
\hline & Pyrosoma spp. & 13.42 & 42.01 & 18.01 & 56.37 & 31.94 & 15.71 \\
\hline \multicolumn{8}{|l|}{ Arthropod } \\
\hline Crustacea & & & & & & & \\
\hline & Isopoda & 1.39 & 100.00 & 1.39 & 100.00 & 1.39 & 1.39 \\
\hline & Euphausiacea & 5.81 & 52.26 & 4.31 & 38.76 & 11.11 & 5.06 \\
\hline & Amphipoda & 0.02 & 1.54 & 0.00 & 0.21 & 1.39 & 0.01 \\
\hline & $\begin{array}{l}\text { Caprellidae } \\
\text { Hyperiidea }\end{array}$ & 0.14 & 10.00 & 0.03 & 2.37 & 1.39 & 0.09 \\
\hline & Vibilia spp. & 0.68 & 24.36 & 0.15 & 5.36 & 2.78 & 0.41 \\
\hline & Crangon & 1.39 & 100.00 & 1.39 & 100.00 & 1.39 & 1.39 \\
\hline & Unidentified crustaceans & 4.96 & 51.02 & 3.03 & 31.21 & 9.72 & 4.00 \\
\hline \multicolumn{8}{|l|}{ Mollusc } \\
\hline Cephalopoda & & & & & & & \\
\hline & Doryteuthis opalescens & 4.19 & 50.25 & 7.28 & 87.39 & 8.33 & 5.74 \\
\hline Gastropoda & Pterotracheoida spp. & 0.48 & 17.21 & 0.01 & 0.36 & 2.78 & 0.24 \\
\hline \multicolumn{8}{|l|}{ Annelida } \\
\hline Polychaeta & & 2.19 & 39.40 & 3.19 & 57.35 & 5.56 & 2.69 \\
\hline
\end{tabular}

